

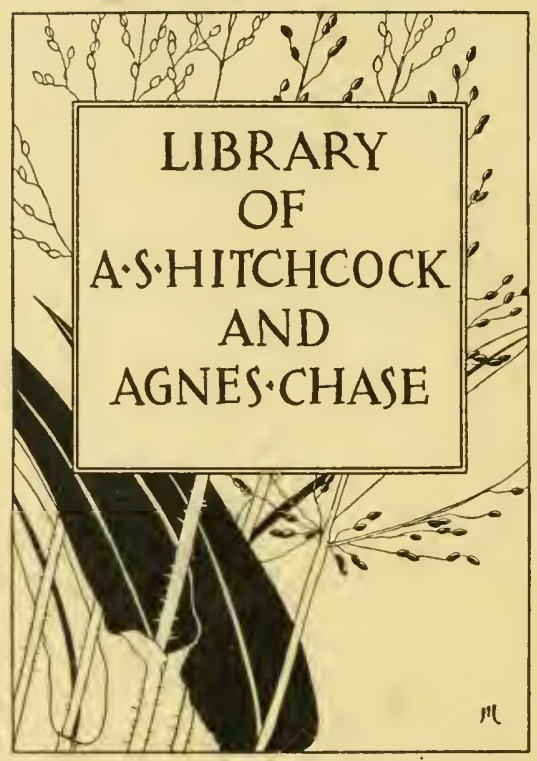







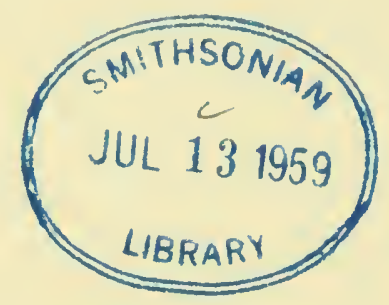




\title{
BIOLOGICAL SOCIETY OF WASHINGTON
}

\author{
NOTES ON GENERA OF PANICEAE. I. \\ BY AGNES CHASE. \\ 211
}

One of the chief distinguishing characters of this tribe of grasses is the single fruit, composed of the more or less inclurated lemma and palea, the latter firmly clasped by the margins of the lemma (rarely loose, as in Leptorory/phium and Hymenuchne), enclosing the free grain. This simple arrangement is variously modified in the different genera. After several years' study of the fruits of this tribe the writer proposes to offer this and subsequent papers on the genera with special reference to the fruits, figuring and describing the fruit of the type species of each genus.

It may be well to state why the character of the fruit is held to have superior generic value. It is because: 1. "The character of the fruit is constant in the sane species. The first glume may be present or obsolete in Paspalum distichum L., P. Drummondii Vasey, P. bifidum (Bertol.) Nash, and in a few others, not only in the same speeies but in the same specimen, but within are always the same plano-convex, chartaceous-indurated fruits, the lemma with inrolled margins, the palea included at the apex as well as on the margins; Reimaria oligostachya Munro may lack but one instead of both glumes but the fruit remains constant; Echinochloa crus-galli (L.) Beauv. may have very long awns or be mucronate only, but the fruit will have the characteristic abruptly acuminate apex, the palea free at the summit. 2. The fruit with but slight modifications is constant for greater or smaller groups of similar species; that is, taking the fruit as a generic character it assembles species which show other resemblances, and does not arbitrarily assemble those which show no close affinity, as cloes the character of the presence of the first glume in Paspalum, which places in Dimorphostachys, founded on Posfabtum monostachyum H. B. K., such diverse species as P. Drummondii Vasey and P. Schaffneri Fourn., when both have 34-Proc. Biol. Soc. Wash, Vol. XIX, 1906. 
nearer relatives beft in the genus Puspolum. The foregoing does not mean that the fruit is held to be the only generic character lut merely that it is a strong one which has not received the attention it deserves; while it is held that any generic character must be constant in a species and assemble species having other aftinitius. Such a character is the reversed position of the spikelets in Axomopus Beauv. (Amastrophus Schlecht.). The fruits alone would not separate this genus from Prespulum, but not one of the many specimens of the several speries examined shows a spikelet placerl otherwise than with the back of the fruit turned from the rachis.

These studies are hasert on the material in the National Herbatrium where all the genera of this tribe are represented, most of them ly a large series of specimens. The figures* and descriptions are drawn from mature or nearly nature fruits; since the spikelets fall at maturity it is rifficult to find perfertly ripe fruit in herlatiun sperimerms.

The present paper is confined to that group of Paniceace in which the fruits are cartilaginous-indurated (not rigid) papillose, and usually dark colored; lemmas and paleas alike in texture, the lemmas with more or less prominent, white, hyaline margins not incolled.

KEY.

Lemma boat-shaped, margin narrow ........ Anthrenantin Lemma convex only.

Palea not incloserl alove, lemma hyaline at the summit. Leptocoryphium Palea incloserl, lemma with broad hyaline margin nearly to the lyase.

Fruit lanceolate-acuminate, second ghme and sterile lemma clothed with long hairs exceeling the spikelet, grain unequally biconvex . . . . . .

Fruit elliptic; recond ghme and sterile lemma clothed with short hairs or nearly glabrous, grain planoconvex in section.

Spikelets disposed in 1-sicled racemes which are digitate or racemose . . . . . . . . Spikelets in panicles divergent at maturity . . . .

Tinlolee

(ikNus ANTHAENANTIA Beanv. 1812. Agros. 48. t. 10. f. 7.

Axis panjeulatns: Panicula subsimplex-Glumæ subrequeles, concave, herbaceae.-Flosc. InfEli. neut.: Paleæ membranaceae, opposita, I'uleis

* The figures are all magnified $\$ 9$ diameters. 
hermaphroditis contrariè dispositx.-Fr.osc. super. hermapl.. Paleæ subcartilagineae.-SFEc. Phalaris villosa MI ICH.

Plualaris? villosa Miclux. 1803. Fl. Bor. Am. 1: 43. "HAB. in sylvis sabnlosis Carolinæ."

Just what is meant by the paleae of the neuter floret placed contrariwise to those of the perfect floret it is difficult to decide. The figure shows such an empty floret consisting of a small lemma and palea placed laterally against the palea of the fruit. Kunth (Fev. Gram. 1:217) reducing the genus to Panicum with the specific name of ignoratum, remarks that "Beaurois who never soaked the spikelets before examining them nor" used a needle to open then "mistook the torn margins of the sterile lemma for a 2-valved floret.

Auluxanthus Ell. 1816. Bot. S. C. \& Ga. 1 : 102.

"Flores paniculati. Calyx 2-valvis, 1-floris; valvis sequalibus, sulcatis Corolla 2-valvis, subaequalis."

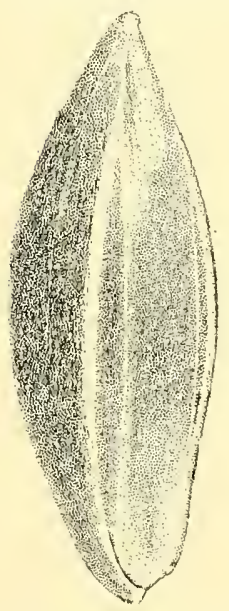

Two species, A. ciliatus and rufus are described, and "Phalaris villosa? Michx." is given under the first. Though the generic description says the spikelets are 1-flowered, under ciliatus is stated: "at the back of the interior valve occurs a neutral floret, 1-valyed, ovate, 2-cleft, green."

Auluxia Nutt. 1818. Gen. $1: 47$. Description is nearly identical with that of Elliott, "1-flowered, with the rudiment of a second" added; Aulaxunthus is given as synonym; no reason is assigned for changing the name.

These three generic names are founded on the same species.

Description.-Spikelets in narrow panicles, obovoid, first glume obsolete, second glume and sterile lemma subequal,very broad, with 5 strong nerves, the very thin internerves deeply folded and densely clothed with long hairs, the sterile lemma enclosing a small palea and sometimes a staminate flower; fruit as long as the glume, plano-convex, subacute, chestnut brown, the lemma boat-shaped, the 3 nerves visible; the white or pale margins very narrow; palea enfolded its entire length, the 2 nerves visible; grain in section plano-convex.

Genus LePTOCORYPHiUM Nees. 1829. Agros. Bras. 83.

Calyx uniglumis, biflorus, gluma inferiore, deficiente. Flosculus inferior - neuter, unighmis * * * Flosculus superior hermaphoditus, calycis longitudine, in fructu persistens chartaceus (nec induratus), valvulis attenratis apice membranaceo-hyalinis lacero-ciliatis. [Whence the name

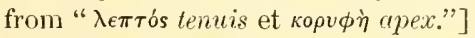

The first species under this genus is L. lanatum (H. B. K. ) Nees, based on Paspalum lanatum H. B. K. 1815. Gen. Pl. et Sp. 1:94. t. 29. "Crescit in regno Mexicano prope Venta del Cameron et Alto del Peregrino."

Roemer \& Schultes (1817. Syst. Veg. 2 : :222) transfer this species to Milium, in which disposition of it they are followed by Kunth (1529. Rev. 
Gram. 497), and Trinius (1834. Mem. Acad. St. Petersb. VI. $3^{2}: 121$ ). Bentham (1SS1. Jonrn. Linn. Soc. Bot. 19 : 39) transfers it to Inthapnantice stating: "From these [N. Am. Authaenumtia] I can not separate generically the Sonth American Leptororyphium Nees, which besides some slight specific characters only differs from the North American species in the secont glume being constantly, instead of oreasionally only, empty." Hemsley (18s. Biol. ('ent. Am. Bot. $3: 483$ ) follows Bentham ; Fonmier (1S81. Mex. PI. 2:13) npholds Leptocoryphinm.

Dscriptim.-Spikelets in narrow panicles, lanceolate; first glume obsolete; second ghmme and sterile lemma 3 and 5 nerved, the internerves, which are not broad and infoleded (or plaited) as in Authremmtir, each with a row of long coarse hairs arising from tubercles (the tubercles sometimes obscure), the second glume shorter than the sterile lemma which equals the froit and which is empty; fertile lemma slightly cartilaginousindurated, minutely papillose (the papillae finer than in any of the other genera), chestmut with a white, delicately hyaline, summit, lacerate and often sparingly ciliate, a narrow liyaline margin extending down the sides to ahont the mildle; on the back near the base

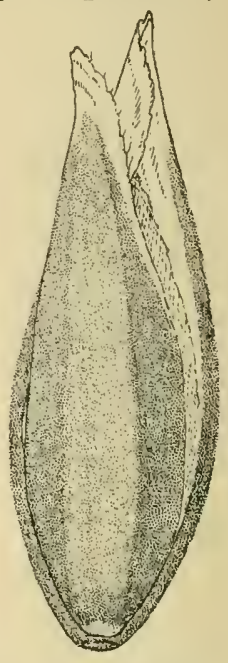
is a small impressed area thin and white; palea with summit and margins like those of the lemma, not encloserl above, the 2 nerves obscurely visible; grain oblong-elliptic, in section plano-convex.

As shown by the fruit this seems to be, as Nees considered it, most nearly allied to Vuhutu (Trirluchme Nees) from which he separated it chiefly on the absence of the first glume. The inflorescence is like that of Anthrenamtir, which it resembles al:o in lacking the first glume, but cliffers from in lacking the nenter palea or staminate flower and in the convex, not boat-shaped, lemma with a lond hyaline summit. It differs from both Vulote and Anthermution in the frnit open at maturity. (A large number of specimens were examined and mone in or past bloom were found closed.) Since this speries lits so prorly in any other genns it seems wisest to maintain the one Nesestablished for it. Nees' single other speries of Inptocoryphimin we have not seen.

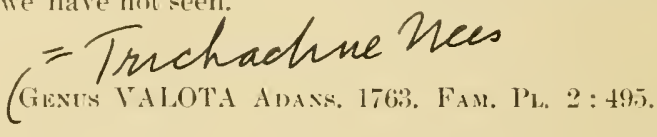

Gramen. Avenae. Sloan. t. 14. f. 2. Comronne de la gaine des feuilles: Membrane médiocre. Fleurs: Panicule étagée. Calice: Ovoide, sans arêtes, à 3 bales velues. Corolle: Sans arêtes.

The reference to Sloane serves to identify the genus, which the very insufficient description wonld not do, and fixes its identity with Andropogon insulare L.

Andropogon insulare L. 1759. Pugill. Jam. 30; and SP. Pl. Ed. 2. 1763. $2: 1480$. In the Pugillus no citation is given; in the Species Plantarum 
the previous publieation by Linnaeus is cited, and also Brown Jam. 365, and Sloane, 1 : 43. t. 14. f. 2. "Hab. in Jamaica."

Brown (l. c.) after his polynomial cites Sloane t. 14.

Sloane's figure (3. c.) is an excellent representation of the nperer portion of the plant, a leaf and overmature panicle.

Panicum lanutum Rotth. 1776. Descr. Pl. 3. Based on Androprigon insulare L.; the same reference to Sloane is also given. Here follows the first adequate description of the species, even the fruit being described: "Corollæ valvæ 2 lanceolatæ, concavæ, acutissimæ, membranaceæ."

Milium villosum Sw. 17SS. Prod. 2t. Based on Andropogon insulrere L.

Beauvois 1812. Agros. 150, in the index refers Andropogon insularis to Monuche, but this species is not mentioned under that genus on p. 49.

Punicum lencophoenm H. B. K. 1815. Nov. Gen. et Sp. 1 : 97. Based on Andropogon insulare L. This species and P. adscendens 11. B. K., which is Syntherisma sanguinalis or a close ally, are placed together under "3) Spicis verticillatis, fasciculatis aut paniculatis (Digitariæ plurimæ)."

Punicum insulare Meyer. 181S. Prim. Fl. Esseq. 60. Based on Antropogon insulare L. The "valves of the corolla" are given as coriaceous with membranaceous margins.

Acicarpe Raddi. 1823. Agros. Bras. 31. with one species A. sacchariflora Raddi l. c. t. 1. f. 4. This is given on the anthority of Nees. We have not seen the original publication.

Tirichachne Nees. 1829. Agros. Bras. S5.

(a $\theta \rho i \xi$ capillus et ä $\chi \nu \eta$ gluma.)

Calyx bivalvis, subbiflorus, gluma inferiore minuta. Flosculus inferior univalvis vel bivalvis hirsutus, neuter; superior hermaphroditus, valvulis membranaceis mucronatis Caryopsis flosculi valvulis membranaceis vestita

* * * Inflorescentia : racemi elongati, simplices, unilaterales, verticillatim paniculati. Spiculae geminae ternaeve, altera brevius pedicellata. * * * Flosculus hermaphroditus * * * bivalvis, glaber, membranaceus, valvulis lanceolatis in mucronum subulatum attenuatis ad fructum persistentibus membianaceo-chartaceis caryopsin tegentibus neque cum eadem induratis. * * * Differt a Panico praesertim gluma flosculi hermaphroditi, *** at minime crustaceo seu cartilagineo indurato sed semper flexili.

- Acicarpa Raddi 1823. Agros. Bras. 31. t. 1.f. 4. is cited as synonym and a note of explanation added that the name is expunged because of its similarity to A cicarpha Juss. [1803]. Nees' first species is Trichachne insularis (L.) Nees, based on Andropogon insulare I. Five other eperies are included, T. sacchariflora (Raddi) Nees, and fonr new species from Brazil, T. recalva, tenuis, velutina, and ferruginen, the last two of which Nees says he saw in the Royal herbarium at Rerlin.

Grisebach (1864. Fl. Br. WV. I. 557) places Panicum insulare and P. saccharatum Buckl in Tricholnena ; Stapf (1S98, in Fl. Cap. $7: 382$ ) transfers "Panicum leucophnen. Sw." to Digitrria, remarking, "the structure of the spikelets is * * as in Digiturin." Stapf probably means P. leucophoeum H. B. K., which is a typonym of A. insulare L. Swartz did not publish the name given by Stapf. Millspaugh and Chase (1903, Fl. Yucatan,

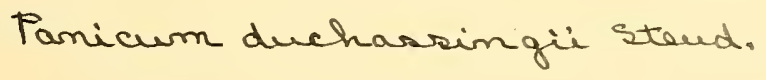


Field Col. Mus. Bot. $3: 23)$ transfer T. insularis to Syntherisma, remarking:

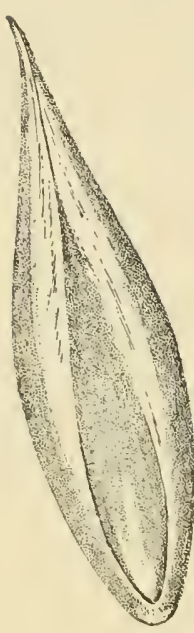
"That this species belongs in the genus Symtherisma rather than in Panicum is shown chiefly by the fruiting glumes which are of the form characteristic of the former, having a floral glume with hyaline margins not inrolled."

Deseriptim.-. Spikelets in pairs, short-pediceled in 2 rows along one side of a narrow rachis, the slender racemes erect or nearly so, solitary or fascicled along a common axis forming a narrow panicle; spikelets lanceolate, first glume minute, glabrous, the seend and sterile lemma usually as long as the fruit or longer, $3-5$ nerved, copionsly clothed with long silky hairs (in one species, only, the silky hairs are not long and (lense); fruit lanceolate, usualby brown, the flat, white, hyaline margins broad; grain ellipsoid, in section unequally biconvex.

This genus is very closely allied to Symtherisma Walt. One species, Punicum Pittieri Hack., has the inflorescence of Fulotu, but the hairs on the second glume and sterile lemma are not long and copious, and the second glume is shorter than the fertile lemma as in some Syntherismas.

But considering the diverse aspect of the two genera as a whole it seems wisest to regard them as distinct.

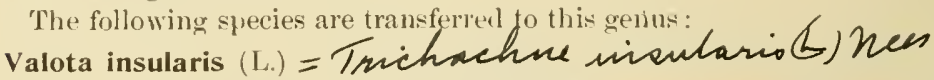

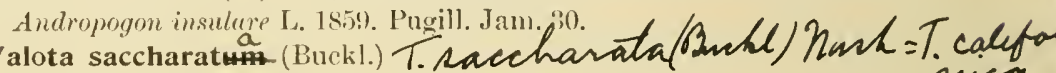

Punicum lachumthum Torr. 1856. Pae. Rail. Rep. $7^{3}$ : 21, not Hochsf. 1855.

Panicum sacchuratum Buckl. 1866. Prel. Rep. Geol. \& Agr. Surv. Tex. App. 2. "Mirldle Texas."

Trichachne succharatum (Buckl.) Nash. 1909 in Small Fl. So. U. S. 83.

Valota Pittieri (Hack.) = Vuchachue futtreri(Hack) Hitche

Panicum Pittieri Hack. 1901. Oest. Bot. '/eitse. i1 : 36. "Costarica: in ripa rivi Rio Tirili prope Sin José leg. Tonduz: Pittier distribuitsub nro. 6! $45 . "$

The species represented in American herbaria by Nealley's Texas collec-

Trichachne temuis Nees) does not well agree with Nees' description. Since authentic specimens of this and Nees' other Brazilian species have not yet been seen, his speries and the Texas form are left for future stuly; and to avoid the possibility of making unneressary combinations by taking up possible synonyms these species and an Australian one with stramineous fruits are not here transferred to this genus.

Genus SYNTherisita Walt. 1788. Fl. Carol. 76.

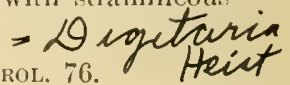

Digitaria Haller 1768. Stirp. Hely. $2: 244$ not Adans. 1763, nor Heist. 1759 , though Haller gives Heister and Adanson as authors of his Irigitaria; but his description, though he evidently makes an effort to harmonize it 
with those of Heister" and Adanson by emphasizing the "excavations" of the rachis, applies not to Tripsacum but to the grasses so long known as Digitaria, and his pre-Linnaean references lead to $P$. sanguinale $\mathrm{L}$.

Antiquum nomen, \& characteristicum, reddo plantis nostris, quæ adeo vehementer a LinN.xis Pamicis abludunt, ut nullo modo eo referri possint. Receptaculum Tritici, altemis scrobibus excavatum. Ad eas scrobes applicantur flosculi petiolati. Calyx biglumis, lineatus, altera gluma parva, mucronata, altera majori faciei floris respondente, lineata: ita mucronata, compressa, ovato lanceolata uniflora, locusta oritur. Flos durus, nitens, siccus, convexus inde, hine complanatus, \& linea quasi divisus, non tamen penetrante. Nonquam satis potui distinguere divisjonem in duas glumas. In cavea certe undique clausa semen sedet, compressum, planum.

Under his first species, to which Haller, who evidently opposed such an innovation as a binonial system, applies a polynomial, "L.1NN. p. 84 " is cited, with Linnaeus' description of $P$. sanguinule used as a polynomial, the name sanguinale being omitted. The reference is to the 1762 edition of Species Plantarum. For discussion of Digituria Heister see Hitchcock, Bot. Gaz. 38 : 298, and Nash; Bul. Torr. Bot. Club 25 : 289.

Panicum sanguinale L. 1753. Sp. PI. 57. "spicis aggregatis, basi interiore nodosis, flosculis geminis muticis, vaginis foliorum punctatis. * * * Habitat in America, Europe australi."

The specimen under this name in the Limnaean herbarium is the traditional P. sanguinale fide'Prof. A.S. Hitchcock who has seen it. The first reference after the description is to Royen Fl. Leyden 55, where, after the polynomial quoted by Linnaeus, Sloan. Hist. 1 : 113, t. 70, f. 3 is cited. The second reference is to Gron. Virg. 154 [error for 134]. Gronovius refers to Clayton n. 457. Linnaeus' reference (Sp. Pl. 57) to Sloane 1:113 t. 70 f. 2 is evidently an error. The polynomial and figure cited in Royen applies to $P$. sanguinale.

Syntherisma Walt. 17S8. FI. Carol. 76.

Cal. 1-florus, 2-valvis: valvulis planis, acutis interiore minore recta, exteriore lateribus corollam subamplexante. Cor. 2-valvis: valvulis magnitudine et figura valvulae majori calycis simillimis. $* * *$ Semen unicum, calyce corollaque persistentibus vestitum.

The first species is S. pracox Walt. "No specimen in [Walter's] herbarium. There is not much doubt but this refers to Panicum songuinale $\mathrm{L}$. (Digitariı sunguinalis), as stated by Elliott and Michaux." Hitchcock, Sixteenth Ann. Rept. Mo. Bot. Gard. 44.

Michaux (1803. Fl. Bor. Am. 1: 45) includes Syntherisma praecox Walt. as synonym under Digitaria sanguinalis Scop.

This group has been held to be a genus or reduced to a section of Panicum according, seemingly, to the weight given its form of inflorescence. Nees, while noting the less indurated and "always pliable" lemma of Trichachne, does not seem to have noted that the same is true of the group he placed as section Digituriae of Panicum, nor that the differences from Panicum which he points out for Trichuchne do not separate that genus from his section Digitariae. The form of inflorescence does not clearly distinguish this genus from Panicum, since the species known as Punicum Perrotteti 
Kunth (I'aspalum Perrolteli Hook f.) and its close allies have sparingly branched racemes more or less naked at the base forming a panicle not greatly unlike that of I'unicum molifurum and yet are true Symtherismas as shown by the spikelets and especially by the cartilaginons-papillose lemma with flat, hyaline margins. Hooker f. (1896 Fl. Br. Inct. 7 : 10) places these and other species of Section Digitaria in Paspalum, saying "As above defined, I'uspalum includes the Digitaria section of Panicum, which appears to me to be artificially placed in the latter genus, because of the occasional presence of a very minute seale-like glume at the base of what is the ird gl. of Pancum (that opposite the flg.). This minute glume which is present or absent even in the same species, is nerveless and never embraces that above it, as the lowest glume always does* in I'micum proper." The first glume is not only present or absent in the sanse speries in Symtherismm, but sometimes in the same sperimens, as in those of I'. I'errotlli in the National Herbarium. Nash (Bul. Torr. Bot. Club 25 : 2s9) while contending that

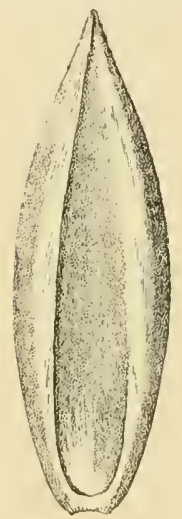
Signtherisme is as worthy of generic rank as are Puspulum, Autharmentia, Eriochlou, Isachur, Ichumblhus, and Tricholefere firils to point out why it is so, and adcls: "Our own view is that symtherismo is more nearly related to Prospalum than to I'unicum, and if its mion with either genus were desirable it wonld certainly be with the former and not with the latter." If the artilaginous-papillose lemma with Hat hyaline margins be taken for the chief generic charanterr, s'maherisme is at once clearly distinguished from both Ponicum and Prespulum, with no intermediatespecies.

I.scriptim.-Cipikelets solitary or in '2's or ?'s, subsessile or short-pediceled, alternate in 2 rows on one side of a 3-ingled winged or wingless rachis, the slenter racemes usually more or less spreading, usually digitate or in approximate fascicles at the summit of the culm, rarely distributed along the axis; spikelets lanceolateor elliptic; first glume minute or wanting, the second glume equalling the sterile lemma or shorter, fruit lanceolate or elliptic, the flat, hyaline margins white or pale; grain subelliptir, in section plano-consex or slightly concavo-convex.

The aftinities of Symtherismu are with lidota on the one hand and $A n$ tharmmin on the other. To the former it is allied through I'. Pittieri and the speries mentioned above as " Prmicum teuerrimum" from Texas. Syntherisma approaches Aulhomantia through I'tenicum (\% Digitaria) adustum Nees and Anthromutin Hurkeli Arech, allied species, and Ponicum budium Scribn. \& Merr., which are placed in Simtherisma rather than in Anthuenantia on the following characters: Spikelets in pairs in 2 rows along one side of a triangular rachis; a minute first glume present (though this has little weight); second glume not equalling the sterile lemma (which is empty or contains only a nerveless rudiment of a palea), neither of them broad with deeply folded internerves as in Anthremantia; lemma not boat-shaped, the hyaline magins broad. In addition to the speries con-

* Hooker was probably not acquainted with the Dichotomous Panieums in which he flrst glume is often nerveless and seldom embraces the second, 
sidered by Nash (l. c.) in his treatment of the genus the following are here transferred :

\section{Syntherisma adusta (Nees) \& Grizht}

Panicum rdustum Nees. 1S29. Agros. Bras. 101. "Habitat in Brasilia meridionali. (Sellow.)"

Syntherisma badia (Scribn. \& Merr.)

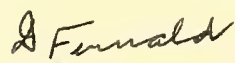

Panicum (Symtherisma) badium Scribn. \& Merr. 1901. U. S. Dept. Agr. Div.

Agros. Bul. 24:12. "Sierra de San Felipe, State of Oaxaca" 915

C. L. Smith.

Syntherisma Hackeli (Arech.)

Q. phaeotrix (Tma) Parodi var hackelii (ancen)

Inthaenantia Hackeli Arech. 1894. Anal. Mus. Nac. Montevideo 2 : 96, t.

5. Figueira, Uruguay.

Syntherisma velutina (DC.)

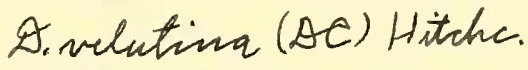

Milium velutinum DC. 1813. Cat. Hort. Monsp. 126. "Hab. in Mexico."

Paspalum? velutinum Kth. 1829. Rev. Gram. 1:27. see Digitaria mollierima

Represented by Pringle 6623 and 9565.

Syntherisma Perrotteti (Kth.) df herrotet. St. Hif: 39

Panicum Perrotteti Kth. 1829. Rev. Gram. 2:395. t. 3. "Crescit in Senegalia, prope Walo."

\section{Syntherisma stenotaphroldes (Nees)}

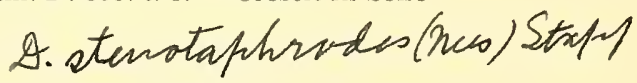

Panicum (\& Digitaria) stenotaphroides Nees 1854 in Steud. Syn. Pl. Glum.

$1: 41$. "Ins. Choin legit Cuming."

This and an allied species are peculiar in having a thickened rachis, the solitary spikelets sunken in the alternate notches.

Species as yet imperfectly understood are not here transferred.

Genus LEPTOLOMA Gen. Nov.

Inflorescentia paniculata, panicula panciflora, maturitate diffusa; spiculae 1-florae, fusiformae, solitariae, aut raro per paria, in pedicellis tenuibus triangularibus; gluma prima minuta aut deficiens, secunda 3 -nervis ; lemma neutrum 5-7 nerve ; fructus ellipticus, acutus ; lemma hermaphroditum cartilagineo-induratum, papillosum, marginibus delicatus hyalinas, planis; palea similis ; caryopsis oblongo-elliptica lemmate paleaque inclusa, libera. Gramina perennia, caespitosa, ramosa, culmis fragilibus, laminis planis, ligulis membranaceis. Maturitate paniculae se dissipant et pervolvunt Panico capillari similes. Nomen ab $\lambda \in \pi \tau \delta$ s delicatus et $\lambda \hat{\omega} \mu a$ margo.

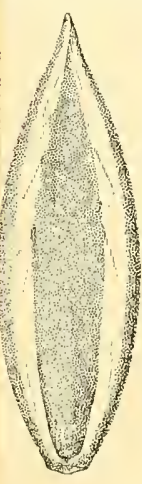

Inflorescence a few-flowered panicle diffuse at maturity; spikelets 1-flowered, fusiform, solitary or rarely in 2's on slender triangular pedicels; first glume minute or obsolete, the second 3-nerved, nearly as long as the 5-7 nerved sterile lemma, a more or less prominent stripe of appressed silky hairs down the internodes and margins of each ; sterile lemma empty or enclosing a minute nerveless rudimentary palae; fruit elliptic, acute, brown ; fertile lemma cartilaginous-indnrated papillose, with delicate hyaline flat margins, enclosing a palea of the same texture: styles long and delicate, stigmas plumose, the branches more long and slender than in Panicun, rather less so than in Syntherisma; grain oblong-elliptic, in section plano-convex; free within the closed lemma and palea . Tufted branching perennials with brittle culms, flat blades, 
and membranaceous ligules. At maturity the panicles break away and ro\}l jike tumble-weeds. Name from $\lambda \epsilon \pi \tau$ bs ilelicute and $\lambda \hat{\omega} \mu a$ border in reference to the hyaline margins of the fertile lemma.

Type.-Imieum rognutum Schultes.

\section{Leptoloma cognata (Sichultes.)}

Prenicum divergens. IInhl. in Ell. 1916. Sk. Bot. 1 : 130. not H. B. K. 1815. Specimen in Elliott herbarium in College of Charleston.

Elliott gives "Mulı]. Cat." without page as authority for this name; in Muhl. Cat. 9 (1813) divergens is a nomen nudum.

Panicum divergens Muhl. 1817. Gram. 120. "Habitat in Carolina." Specimen in the Muhlenberg herbarium in Philadelphia Academy of Natural sciences, narked "Elliott 353." In the same folio with this is a specimen of Ponicum Philudelphicum marked "M. 112l)."

Panicum commutum schultes 1824. Mant. 2 : 235. Muhlenherg's description is copied and $P$. divergens Muhl. is cited as synonym, the name changed, doubtless, because of $P$. divergens H. B. K., though this older use of the name is not mentioned. Thus it is the second publication of $I$ '. divergens Muh]. (that in Muhl. Gram.) on which Schultes bases his P'. cogualum. Hence the sperimen in Muhlenberg's herbarium is the type.

Panicum untummale Bose. Spreng. 1825. Syst. 1:320.

This name as used by American anthors is synonymous with abore, but we have not seen Bosc's specimen. Sprengel (l. c.) places the description of $P$. antummale next to that of $I$. divergens Muhs. The brief description would apply to any Punimu with an effuse capillary panicle. It was not known to Sprengel where the specimen came from; "Patria?" he adds to his description, and indicates he saw the specimen in the Willdenow herbarium.

'The sheaths and blades of this species, especially the lower ones, are often papillose pubescent, commonly so in Western specimens, though the type is almost glabmens. Pringle 489, Chihuahua, Mexico, represents an extreme form with slightly larger spikelets, having dlensely silky-pulescent internerves, which would appear to be a distinct species except for the finct that the inter-grades are more numerons than the extreme form. This is the only species of this genus known in the northern hemisphere. Three or forr species are found in Anstralia.

Leptoloma divaricatissima ( $\mathrm{R}$. Br.)

I'ruicum dimericutissimum R. Br. 1810. Prorl. 192. Port Jackson, New Holland.

Leptoloma macratenium (Benth.)

I'ruicum mucruteninm Benth. 1878. Fl. Australia $7: 468$. "Queensland, Rockhampton, O'sticunesy."

Leptoloma coenicola (F. Mnell.)

I'unicum coenicolum F. Muell. 1855 in Trans. Vict. Inst. 45. Cudnaka, S. Australia, F. Mueller.

I'tuicum prpposum R. Br. Prod. 192, and I'. nemutostuchyum Bailey 1903 in Bot. Bul. Uept. Agr. Queensl. 16: 2, of which we have not seen specimens, probabjy belong here. The former is P. autumme F. Muell. Fragm. 8: 196, not Bos", fide Bentham Fl. Australia $7: 469$. 
OF THE

\title{
BIOLOGICAL SOCIETY OF WASHINGTON
}

\author{
NOTES ON GENERA OF PANICEAE. II.*
}

BY AGNES CHASE.

The two genera, Hymenachne and Sacciolepis, discussed in the present paper, while not very closely related, have been confused because of the similarity in the form of the inflorescence of most of the species in each, a spike-like panicle.

Genus HYMIENACHNE Beaur. 1812, Agros. 48. t. 10. f. 8.

"Axis paniculatus: Panicula simplex, spicxformis: Rami conferti.Glumæ inæquales, herbacer, acutæ: infer. multo brevior. Fiosc. Infer neut.: Palea infer. acuta: super. brevissima, membranacea, hyalina.Flosc. super. hermaphroditus: Palex herbacex membranacex acutæ. * * * SPEC. Agrostis myuros Lam. monostachya PoIr."

The illustration represents the second species mentioned by Beauvois, Agrostis monostachya Poir., which according to the American Code, $\uparrow$ should therefore be taken as the type of the genus, althongh Beauvois gives the

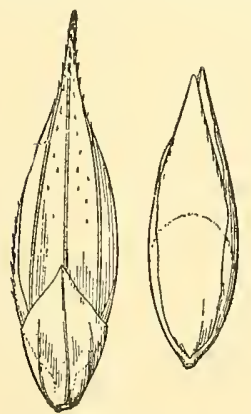

Fig. 1.

Hymenachne amplexicaulis. name Hymenachne myuros in the explanation of plate 10, showing that he misunderstood Lamarck's species.

Agrostis monostachya Poir. 1810, Encyc. Suppl. 1: 256. "Cette plante a été recueillie à Porto-Ricco, par M. Riedle. (I. s. in herb. Desfont.)"

The type labeled in Poiret's hand, "Agrostis monostachya Poir. enc. sup. Reidel Porto-Ricco,"' was examined by Professor A.S. Hitchcock $\ddagger$ in the Desfontaine herbarium at Florence. The accompanying figure is drawn from this specimen.

Panicum myuros Lam. (incorrectly given as Agrostis myuros Lam.) cited by Beauvois under $H y$ menachne is not the same species as Agrostis monostachya Poir., as most subsequent authors seemed to think. The type of this was seen in Lamarck's herbarium in Paris,

* Notes on Paniceae I, with general discussion of the importance of the fruit as a generic character in this tribe appeared in Proc. Biol. Soc. Wash., 19: 183-192. Dec. 1906.

t Canon 15, b.

f All the type specimens definitely mentioned as found in the different European herbaria were examined by Professor A. S. Hitchcock in the spring of 1907. 
and was found to be a congener of Sacciolepis striata (L.) Nash., Panicum indicum, and allied species.

Beauvois emphasizes the simple spike-like panicle, and also the real distinguishing character of the genus, the membranaceous lemma and palea, to which latter character the name refers, "De i $\mu$ ìv" Membrana;

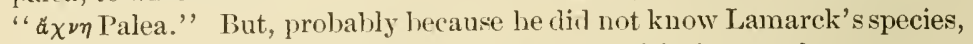
Beauvois included in Hymenachne $P$. myuros which does not have a membranaceous lemma and palea. Subsequent anthors have placed in the genus or section Hymenachne various Panicum allies having a spike-like panicle, but often without other similarity. It is not evident whether Beauvois considered the two species he cites synonymous or not. In the inclex only Hymenachne myuros is given; A. monostachya is not formally transferred and is not mentioned in the index.

Roemer \& Schultes (1817, Syst. 2: 25) maintain this and others of Beallrois' new genera without comment.

Trinius (1820, Fund. Igros. 176) upholds Hymenachne as a genus with one species, myurus, though Digitaria, Monachne and other genera are included in Panicum. Trinius adds the note: "Obs. Panicis maxime affinis. An hujus generis (forte tunc emendandi) Andropogon insularis L.?" which seems to indicate that he gave greater weight to the membranaceous fruit than to the spike-like pranicle. This is assuming that Trinius supposed $H$. myums and $A$. monostachya to be synonyms. Later (1826. Gram. Pan. 51) Trinius places Hymenachne together with Trichachne, Setaria, Pemisetum and other genera in Panicum under the following synoptical division "e) Thyrsus (simplex vel compositus), ant Racemi compositi longe plerumque sparsi et jubati. Spiculæ oblongæ 1. lanceolate, pl. min. inequaliter disposita. Gluma inferior manifesta (Jubaria).*)" ["*species quarum radii, quantum vis racemos mentientes, radiolos, distinctos emittunt, ad sectionem sequentem Miliariam referuntur."] This gives a wholly artificial grouping based solely on the narrow panicle and include- Chictochloas, various true Panicums and allies. Jubaria (1. e. p. 15!-18:3) is sublivided into four groups, the third of which, “* * * Tlyyri pl. min. compositi spiculre basi nudæ (absque involucello)" includes Panicum indicum L., P. vilvoides Trin., P. gibbum Ell. (which belong in Sacciolepis), and $P$. amplexiraule Rudge (true $H y$ menache) under which Hymenachne myuros Beanv. and Panicum myuros kunth "(nec Lam.)" are given as syuonyms. Trinius observes "Lamarekii gramen, eni 'folia angusta, convoluta' c'rte lune non pertinet." But Panicnm myuros Lam. and P. amplexicaule continued to be considered synonymons by other anthors. Under his fourth division of Jubaria Trinius includes Panicum palustre Trin. (a true Hymenachne having a racemose panicle) letween Panicum leucophacum Kunth (which is T'alota) and P. plicatum Lans., which belongs in section Ptycophyllum of Panicum. These details are given only to show that the cause of confusion was the form of the inflorescence.

Nees (1829, Agros. Bras. 27:3) recognizes Hymenachne as a genus, but like Trinius grouns with it the allies of Panicum gibbum Ell., though he places the following observation after them: "Hac in specie ac in prece- 
dente [H. Aluviatilis, which is the same as Panicum vilvoides and H.campestris] floseulus hermaphroditus glumis et neutro flosculo brevior est multo, non vero herbaceus ut in H. myuro, sed subcartilagineus." Panicum paludicola Nees, a Hymenachne, and P. striatum Lam., a Sacciolepis, are given among true Panicums.

Desvaux (1831, Opus. 82) transfers Agrostis monostachya Poir. to Panicum, changing the name to $P$. Hymenachne Desv. He observes that this plant had been confoumled with Agrostis [Panicum] myuros, which was very different.

Kunth (1833, Enum. Pl. 1: 86) under division j̀ includes a miscellaneous group of Sacciolepis, Hymenachne, Eriochloa and other allies, as well as several species of Panicum itself.

Trinius (1883, Pan. Gen. 165) includes about the same group under his section Virgaria of Panicum.

Nees (1841, Fl. Afr. Aust. 50.) makes a section Curviflora of Panicum for two species of Sacciolepis.

Stendel (1854, Syn. Pl. Glum. 2: 101) includes in the genus Hymenachne four names referable to Sacciolepis, and two (which are, however, synonyms) to IIymenachne; a serenth species, which is probably a Sacciolepis, he includes with the mark of donbt.

Grisebach (1864, Fl. W. I. 558) includes in the genus Hymenachne one species which belongs there and two which belong to Sacciolepis.

Doell (1877, Mart. Fl. Bras. 22: 231) in the first part of the section Miliaria of Panicum gives seven species, five of which are referable to Sacciolepis, one to Hymenachne, and one probably to Steinchisma. Panicum auriculatum, a Hymenachne with ascending, not oppressed, panicle branches, is placed in the second part of the section in which most of the species are true Panicums. It is worthy of note that Doell uses the name Panicum myuros Lam. for the species to which the type really belongs, stating that he saw the specimen in the Paris Museum. Under Panicum amplexicaule Rudge, he straightens out the hitherto confused synonomy of this species.

Bentham (1878, Flora Australiensis $7: 465)$ makes a section Myuroidex of Panicum under which he places three species, two of which belong in Sacciolepis and one in Hymenachne.

Fournier (1881, Mex. Pl. 2: 36) inclutes eight species in the genus $H y$ menachne, two of which are referable to Sacciolepis, three to Hymenachne, and two to Panicum. The remaining species, H. Gouini Fourn., unknown to us, is probably a Hymenachne.

Hackel (1857, Engler \& Prantl. Pfl. Fam. 22:35) recognizes Hymenachne as a section of Panicum with spike-like panicles and slightly indurated glumes. No species are mentioned.

Hooker (1896, Fl. Brit. Ind. 39) places seven species under Hymenachne as a section of Panicum, three of which are referable to IIymenachne and four to Sacciolepis.

Stapf (1898, Flora Capensis 386) makes a section Vilfoideæ for three species referable to Sacciolepis.

Description.-Spikelets short-pediceled, crowded in slender racemes 
which are erect, forming a dense spike-like panicle, or narrowly ascending; spikelets lanceolate, acuminate; first glume $1 / 3$ to $1 / 2$ as long as the spikelet, remote, a distinct stipe below the seeond glume; sterile lemma 5-nerved, acuminate, exceding the lanceolate stramineous fruit; lemma and palea nembranaceons, margins of the lemma thin (not broad and liyaline), not enrolled; palea not inclosed above; grain oblong, at maturity readily falling from the open lemma and palea. Peremial aquatic or semi-aquatic grasses, decumbent at base and rooting at the luwer nodes, with rather stout -imple stems and long lanceolate blades cordate-clasping at base, except in Hymenachne montana. Species seven or eight, confined to the tropies and subtropies.

\section{* Panicles elongated, spike-like.}

Hruexacine amplexiculis (Rudge) Nees 18:9, Agrost. Bras. 276, - based on the next.

Panicum amplexicaule Rudge 1805, Pl. Guian. 1: 21. t. 27. Type "ex herb. Rudge" in the British Museum.

Agrostis monostachya Poir. 1810, Encye. Suppl. 1: 256. (Nee note above on type. )

I'anicum Hymenurhne Des: 18:31, Opus. 82. Based on Agrostis monostachya Poir.

Panicum myuros of anthors not Lam.

In the tropies and subtropics of western hemisphere.

Hraexacune patela Foum. 1881, Mex. Pl. Gram. 37. "Bejueal in insula Cuba (Liebm. n. 402.)"

A specimen of this number from Fournier is in the herbarium of the Botanical crarlen at Copenhagen. The panicle is less dense than in the precerling.

Known only from Cuba.

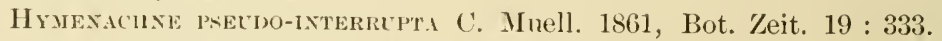
"India orientalis, Bengalia et Malaeea. Griffith.",

speeimens in the National Herbarim from India, Malacea and Java answer to Mueller's description. They differ from $I I$. amplexicaulis in having blades narrowly cordate at base, long-attenuate or involute above; and in the longer spikelets with longer-pointed glumes. Nees' description of P. auritum Presl (ex Nees 18:9, Fl. Bras. 2: 176) seems to apply to this species, but we have not seen the type of either.

Hrangache moxtana (iriseb. 1879, in Goett. Abl. 24: 307. "C ["C = Prov. Cordolsa und Santiago del Estero." 1. c. 4.] S. Achala." The type is in Grisebach's herbarinm at Göttingen, labeled "Achala, Hieronymus 640."

An anomalons species, bearing abont the same relation to the typieal species that Panicum Chapmanii Vas. and related forms bear to Eupanicum. A few of the lower spikelets are subtended by a scabrous bristle (a sterile pedicel); first and second glumes sub-equal, much shorter than the sterile and fertile lemmas; fruit as in the type species, except that it is slightly indurated.

Argentina. 
** Panicle long and narrow with ascending branches, not spike-like.

Hymenachne auriculata (Willd.).

Panicum auriculatum Willd. 1825, ex Spreng. Syst. 1 : 322. "Amer. austr." The type, labeled "Amer. merid. Humbolit," is in the Willdenow herbarium, Berlin.

Panicum polystachyum Presl 1830, Rel. Haenk. 1: 312. "Hab. in Peruvia." (Not P. polystachyum Schult. 1824, Mant. 2: 146.) The type, in the Presl herbarium in the National Museum, Prag, is labeled "Regno montana, Peru."

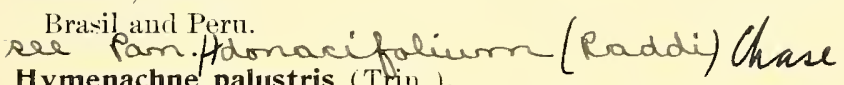

Hymenachne palustris (Ttin.).

Panicum palustre Trin. 1826, Gram. Pan. 181. "V. Epp. Brasil. (Langsdorff.)" The type bearing the label "Panicum palnstre m. Brasil Langsdorff. In fossis serra dos Orgonos," is in the Trinius herbarium, in the St. Petersburg Academy of Seiences.

Panicum paludicola Nees in Trin. l. c. as synonym sub P. palustre; 1499, Agros. Bras. 179. The specimen in Trinius' herbarium is cited and Panicum palustre Trin. is given as synonym.

In the Icones 2, $p l$. 218, Trinius rednces $P$. palustre to a synonym of Panicum frondescens Meyer, but from Meyer's description and a specimen from Brasil determined by Nees this seems to be a species related to Panicum stoloniferum Poir. Plate 218 is drawn from a Brasil specimen, and agrees with the specimens of $P$. palustre in Trinins' herbarium.

Panicle less dense than in the preceding, spikelets, larger.

Brasil.

Two species represented in the National Herbarim, one from Uruguay and one from the Philippines, remain to be identified with published names or to be described.

The following species should be exclucled from Hymenachne, to which genus they have been referred by various authors:
Hymenachne boiviniana Steud. . . . . . . = Sacciolepis?
Iymenachne campestris Nees . . . . . . . = Sacciolepis.
Hymenachne fluviatilis Nees. . . . . . . : = Sacciolepis.
IIymenachne frondescens (Meyer) Fourn. . . = Panicum.
Iymenachne indica (L) Buese . . . . = Sacciolepis.
Iymenachne interrupta (Willd.) Buese . . = Sacciolepis.
Iymenachne leptostachya (Presl) Fouru. . . = Panicum?
IIymenachne myosuroides ( $\mathrm{R}$. Br. ) Balansa = Sacciolepis.
IIymenachne myosurus (Rich.) Yees . . . . = Sacciolepis.
IIymenachne myuros (Lam.) Beaur. . . = Sacciolepis.
Hymenachne phalarioides (R.\&S.) Nees . . = Sacciolepis?
Hymenachne phleiformis (Presl) Fourn. . . = Sacciolepis.
Iymenachne polymorpha Balansa . . . . = Sacciolepis?
Iymenachne striata (Lam.) Griseb. . . . . = Sacciolepis.

None of the above species is here transferred. 


\section{Genes SACCiOlePis Nash 190I, Britt. Man. 89.}

"A peremnial grass with flat leaves and a terminal contracted panicle. spikelets numerous, readily deciduons when mature, 1-flowered, articulated to the pedicel below the empty scales. Scales 4 , the onter 3 membranous, the first scale small, the second one much larger than the rest, many-nerved, strongly saceate at the base; fourth scale much shorter than the third, chartaceous, enclosing a palet of sinilar texture and a perfect flower. *** [Greek, in reference to the large saccate second scale of the spikelet.]."

The only species given under the genus is Sacciolepis gibba (Ell.) Nash (1. c.), based on the following:

Panicum gibbum EH. 1817, sk. Bot. S. C. and Ga. 1:116. No specimen is citel. The type in the Elliott herbarium in the College of Charleston,

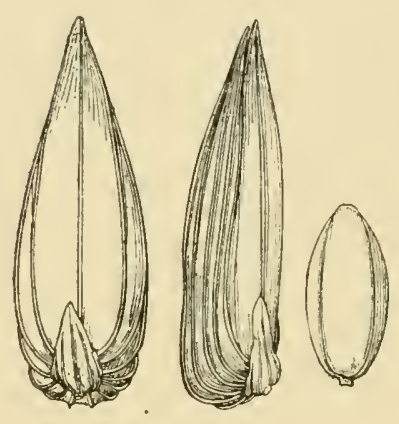

Fig. 2.

succiolepis yillue. consists of a single culm with three leaves and an over-mature panicle. The late] in Elliott's writing reads: "Panicum gihl,um mihi. flor. Aug. Sept. Car. Georg. in loces ndis."

Nees (1s+1, Fl. Afr. Aust. 50$)$ establislie: a clivision Curriftora; Bentham (1878, Fl. Austral. $7: 480$ ) a series Myuroidex; and Stapf (1898, Flora Capensis 386 i) a section Vilfoidea for species referahle to this genus. For the listory of the disposition of this group by varions anthurs, see the notes under Hymmachme.

Description.--Spikelets slort-pediceler on short usually erect racemes forming dense spike-like panicles ('xcept in $P$. curratum L.), spikelets oblongconical; first glume small, second glume broad, inflated-saccate, strongly many-nerved; sterile lemma narrower, Hat, fewer-nerved, its palea nearly as long, often sulstending a staminate flower; fruit stipitate, elliptical, the lenma and palea chartaceons-inclurated, the margins of lemma inrolled, the palea not enelosed at the smmmit. Grasses of wet ground; culms nsually branching, and rooting at the lower nodes.

Sircoldspls strist (L.) Nash 1903, Bul. Torr. Bot. Clul, 30:38:3.

IIolcus striutus L. 1753, S... Pl. 1045. "Habitat in Virginia paludilsus." The type in the Limean herloarium is " a Gronovins plant numbered 59, upon which Linnaeus has written ' 7 striatus.' ", *

Panicum striatum Lam. 1791, Tab. Encyc. 1:17:2. " ('arolina. Com. D. Fraser." The type labeled "de la Caroline, fraser, panieum striatum lam." is in the Paris herbarinm. Thongh the same speecific name is used it appears that Lamarek dill not know Holeus striatus L.

I'rnicum yiblmm Ell. 1817, sk. Bot. S. C. and (ia. 1:116. (Nee above.)

Panicum Elliottiamm Fichult. 1824, Mant. 2: 256. Based on the precetling, the name being elianged becalse of $P$. yiblosum Brown.

- Fide Hitchcock, in note book. 
Panicumaquaticum. Bosc ex Spreng. 1825, Syst. 1:319. "Ins. Bermud." A duplicate type was seen in the Webb herbarium in Florence.

Sacciolepis gibba (Ell.) Tash 1901, Britt. Man. 89. (See above.)

\section{Sacciolepis myuros (Lam.)}

Panicum myuros Lam. 1791, Tab. Enc. 1: 17.2. (Misprinted "myruos," but corrected in Enc. 4: 748.) "Ex America merid. Comm. à D. Rich-

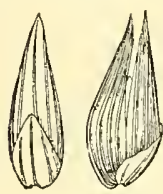

Fig. 3. ard." The type in the Lamarek herbarimm in Paris is labeled in Lamarck's handwriting "de Cayenne Leblond Panicum myuros lam. ill. gen." In the Encyclopédie $(4: 748)$ the specimen is said to come from Cayenne, communicated by Richard and leblond.

Sacciolepis myuros.

- Since this species has been so generally misunclerstood a spikelet from the typu is illustrated here to show the generic relationship.

Panicum myosurus Rich. 1792, Act. Soc. Hist. Nat. Par. 1: 106. No specimen is cited, but the name is published with a brief diagnosis in a "Catalogus plantarum * * e Cayenna missarm a Domino Le Blond." The type is in the Paris herbarium. It is a somewhat larger specimen than the preceding type.

This species is represented in the National Horbarium by Liebmam Mex. Gram. No. 146.

?Panicum phleiforme Presl 1830, Rel. Haenk. 1 : :02. "Hab. in Mexico." There are two specimens on the sheet labeled " P'anicum phleiforme nov. sp. J.S. Presl", in the National Museum at Prag, one ticketer Mexico, the other Luzon. The Mexico specimen is small and slender, but may be referable to S.myuros; the spikelets agree with those of Lamarck's specimen, except that they are less acute. Pringle 9368, Jalisco, Mex., distributed as $P$. indicum L., seems to be the same as Presl's specimen. More material may show this form to be distinct.

\section{Sacciolepis vilvoides (Trin.).}

Panicum vilvoides Trin. 1826, Gram. Pan. 171. "Hymenachne fluviatilis N. ab Es! in Mart. Fl. Bras. ined. V. spp. Gujan. Brasil. (Fischer X. ab Esexb.)" In the Trinius herbarimm there are two specimens in the cover marked "Panicum vilvoides m." One is labeled "Panicum vilvoides m. Hymenachne fluviatilis $\mathrm{N}$. ab Es. sub quo nom. mis in Brasil. lectu an. N. ab." The other is labeled "Ianicum (Hymenachme) vilroides Trin. Guyan française." Fischer's name does not appear on either. since Trinius indieated by " $m$ " or "mihi" the specimen he named, the first specimen mentioned above may be taken as the type. The second specimen is S. myuros.

IIymenachne fluviatilis Tees 18\%6, in Trin. (l. c.) as synonym sub Panicum vilvoides Trin. 18.9, Fl. Bras. 27:" "Panicum vilvoides Trin. in litt., ex Herb. cl. Fischeri." is cited.

This species is represented in the National Herbarimm by Edwall 1066 $\therefore$ Paulo, Brasil. Other specimens apparently belonging to the same species have spikelets hirsute at the summit.

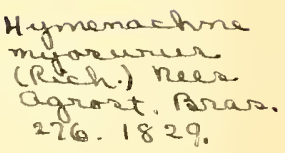


Sacciolepis strumosa (Presl).

Panicum strumosm Pres] 1s:3, Rel. Haenk. 1: 80:3. "Hab ad MonteRey Californize." The tyle in the Presl llerlarimm is labeled "Panicum strumosum nov. sp. J. s. Presl"; a recond slip reads " Regno montane, Haenke." The publisled loeality is clearly a mistake; no species of this group have been found in Californit. This species is represented in the National Herbarium by Burchell 4q30, Brasil.

\section{Sacciolepis indica (1.)}

Aira spicata L. 175.). No. Pl. (i.). "Habitat in India." In the Errata at the end of Vol. 2" "spicatum" is (hanged to "indicum," presumab)ly hecalse of another tim spicata on lage (it. "The speeimen in the Linnean herbariun is a delicate creeping or sprealing plant with many spikes ahout $1 \mathrm{~cm}$. long with only al few spikelets" - [Titcheock in notebook]. It is labeled in Linnatems" hamel "Panicum indicum." Aira has been seratehed, and indien changerl to indicum.

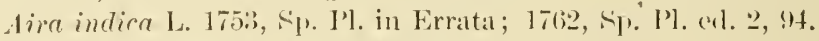

Panicum indirum L. 1761, Mant. "2: 1st. Based on "Aira indica Ap. plant !t" (the reference is to the seconel idition).

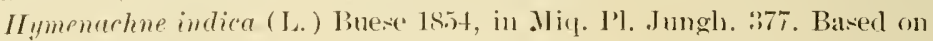
I'anicnm indicum l.

of the several species in the National IJerbarium, from India received as I'anicum indiram 1., that reprevented by Inthie $10,00.3$ from the herbarium of Prof. Hackel eems to be the true I'. indicum.

\section{Sacciolepis curvata (1.).}

Panirum curratum L. 1767, "Yyst. Nat. ed. 1:2 : 73:2. "Habitat in suratte."

"Prwicum coryophorum kinnth is:31, liev. Giram, 2: :38т. t. 107. "Crescit in Martagascaria." Communicated ly Auhert du Petit-Thouars. Kunth renarks that while the description of $I^{\prime}$. curratum $\mathrm{L}$. might inchurte his species, it is nevertheless tou lorief to convince him of the identity of the two, aspecially since me is from India and the other from Marlagascar. The Marlagasear speeimen in the National Herbarimu agrees perfectly with Kunth's fignre, lut the irlentity of $I$. curcatum $\mathrm{I}$. and $P^{\prime}$. roryophorum Kunth can only bedetermined by a stuly of the types. The two are consicteresl synonymons ly Hooker, Statif and others. This is the only known species with an open panicle. The spikelets closely resemble those of the type species, S. gibler.

The following species whelh lxelong in this gentw are not here transferred for lack of complete lata:

I'micum rigidifolium Trin. 18:2), Sp. (iram Ic. 2. t. 214. "Figura ad -pecimen Brasiliense." The type in Trinins herbarium, St. Petersburg, is labeled "l'anictm rigidifolimm n. + Bratil. Langsilorfl."

This is an ontstanting speries with a fruit larger in proportion to the size of the -pikelet than in any other species. It is not here transferred lecanse of morertainty as to the oldest tenable name. Kunth (1833, Enum. Pl. 1: S8) changes the name of $P$. rigidifolium Trin. to Panicum 
Trinii Kunth because of P. rigidifolium (Poir.) Kunth (May 2,* 1829, Rev. Gram. 1:37). Both names thus date from 1829, and we have not been able to ascertain which is the earlier. An older name than either may apply to this species. Doell (1877, Mart. Fl. Bras. $2^{2}$ : 236) uses Panicum diceum Spreng. (1825, Syst. 1: 322) for this species, citing "Panicum melicoides Nees ab Esenb. secundum specimena authentica, vix Poiret." Sprengel's description is very brief, and does not seem to apply to this species; the spikelets are said to be diøcious and the leaves lanceolate. The native country is indicated as unknown, and "P. melicoides et poreforme Poir." are cited as synonyms. Nees (1829, Agros. Bras. 191) describes this species under Panicum melicoides Poir., giving Panicum dicecum Spreng. as a synonym. Since Nees might be expected to have seen Sprengel's specimen it may be that Sprengel's name belongs to this plant, notwithstanding the inapplicable description. The original description of P. melicoides Poir. (1816, Encyc. Suppl. 4: 283) could hardly apply to this species. Neither the type of this nor of $P$. dicecum has been seen.

Two other Brasilian species, Hymenachne campestris Nees (of which $=$ wa Panicum camporum Kunth is a typonym) and $P$. caudatum Salzm.; and Panicum interruptum Willk, of India, and a number of other old-world species of this group are not well enough known to us to be transferred here.

*Fide Sherborn and Woodward in Journ. Bot. 39 : 205. 1901. 





\section{BIOLOGICAL SOCIETY OF WASHINGTON}

\section{NOTES ON GENERA OF PANICEAE. III**}

BY AGNES CHASE.

The grasses in Paniceae having two forms of spikelet $†$ form one well-defined group, the Olyrae, an outstanding genus, Amphicarpon, and a small group of polygamous grasses, Phyllorachis, Thuarea and Spinifex, not closely related to each other nor to any other genera in this tribe. The latter group will be taken up in a later paper. In natural systems these forms have been disposed of in various ways, only the more important of which are here considered, as the history of the classification of this tribe will be taken up later.

Beauvois' $\div$ disposition of these forms is interesting since his is the first attempt at a systematic arrangement of all the known genera of Gramineae into divisions and subdivisions. His confidence in the enduring excellence of his Méthode, however much the rest of the Essai might fall short of perfection, is also interesting.§ He places these forms in "Familia II. Polythalama. Locustae dissimiles;" "Tribus quarta, axis integer. Glumae alternatim insertae," [as distinguished from tribe III Tripsacum, etc.]. Olyra comes under "Cohors Octava. Axes androgyni", with Zizania and Pharus, while Lithachne comes under "Cohors Nona. Axes monoici aut dioici. Sectio Prima. Axes monoici"

* Notes on Paniceae I appeared in Proe. Biol. Soc. Wash. 19: 183-192. Dec. 1906; Notes on Paniceae II op. eit. 21: 1-10. Jan. 1908.

t The text figures in the present paper are all magnified 5 diameters only, as most of the fruits in this group are unusually large.

$\ddagger$ Agros. tab. meth. and pp. $124,135,137 ; 1812$.

$\$$ Les changements qu'on pourra y faire par la suite, pourront porter sur quelques details, sur des reunions ou des separatious de genres; mais je ne pense pas qu'ils puissent attaquer en rien les bases et les principes de la Méthode. Les geures y sont tous distingues par des earacteres certains, constants et faeile a saisir." Op. cit. Avertisse. ment. 
together with Hydrochlou, Zeu and Coir, while Spinifer comes in "Sectio secunda. Axes dioici" with Gynerium.

Humboldt, Bompland and Kunth (1815, Nov. Gen. 1:196) propose a "Section IX Olyraceae " which includes Phar"us, Olymre and Luziola. [Pamicere is their Section I.] Kunth (1815, Mem. Mus. Hist. Nat. 2:75) proposes a group "Gramina Olyrea", which ineludes Zizania, Luziola, Hydrochloa, Pharus, Olyna, Zea, and Coix:

Trinius (1826, Gram. Pan. 53, 55, 247, 249), places Olyra and Milium amphieurpon in his "Paniceorum Genera."

Nees (1829, Agros. Bras. 298) establishes "Familia Secunda. Gramineac Olyreae" for Strephim, Caryochlod, Luziola, Phares, Olyo and Coix (Family I is Panicene).

Kuntlı (1833, Enum. Pl. 67-70, 174) plates Amphicarpum, Olyneac and spinifex in "III Paniceae" which is very nearly the tribe Punireue as recognized to-day, and subsequent authors generally have followed this disposition of these forms, though often associating Iharus and allied genera with them under Punirsue.

Though the Olyrae and Spinifex depart rather widely from the Pomicum type, their aftinities are clearly with this tribe. Litharhe baur. forms the only known exception to the tribal character of fruit dorsally compresser or subcompressed.

OLYREAL: Plants monneeions; blades flat, abruptly narrowed into a petinle-like base, convolute in the bud, the consequent creases persistent in the nature balke. First glume wanting in the pistillate sjukelets, both glumes and sterile lenma wanting in the staninate spikelets.

KEY.

Inflorescence borne on leafy culns; fruit hony-indurated:

Panicles terminal on culms or leafy branches, pistillate spikelets above, staminate spikelets below, in sane panicle . . . . . . . . . . .

Panicles all axillary or axillary anıl terminal; the termiOlyra nal when present wholly staminate:

Fruit laterally compressed, conspicnously gibbous on

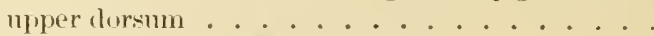

Fruit ilorsally compressed, lanceolate . . . . . .

Lithachne Raddia

Inflorescence consisting of 2 slenter racemes, one staminate, the other pistillate, cligitate at the summit of a naked culm; leafy stems distinct from base; fruit scarcely indurated 
Genes OLYRA L. May, June, 1759, Srst. Nat. ed. 10. 1261.

"Nase. Cal. Gluma uniflora, aristata, Cor. Gluma mutica.

"Fem. Cal. Gluma miflora, patula, ovata. Stylus 2-fidus. Sem. cartilaginemus.

"latifolia A. Olyra. Bloan. jam. t. 64. f. 2."

The figure referred to in Sloane represents the upper portion of a culm with three leaves and a short exserted panicle, large spikelets on clavate pedicels at the ends of the branches ant small spikelets along the same branches from the base. The polynomial given is "Gramen paniceum majus, spica simplici laevi, granis petriolis insirlentibus."

The type, from which the figure was marle, is in the Sloane herbarium. The specimen in the Linnaean herbarium, from Jamaica, marked "Br" [Browne] agrees with the Sloane specimen. In Pugill. Jam. Pl. 408. Dec. 1759, Linnaens gives a description of the species $O$. latifolia.

Mapira Aclans. 176:3, Fam, 2 : 39.

"Couronne de la gaîue des feuilles: Membrane courte. Fleurs: Panicule \& épi. Calice: 1 fleur, 'ב bales \& 1 arête. Corolle: 2 bales."

In the "table" or index, page 574, nuder" Mapira Arlans 39 " is eited "Gramen. Sloan. t. 64. f. 2. Olyra. Lin." This is the figure upon which Linnaeus bases Olyra latifolia.

Description.-Spikelets unisexual, unlike in appearance, the staminate and pistillate together in panicles terminating the culm or leafy branches, the pistillate spikelets on clavate pedicel- on the upper panicle branches

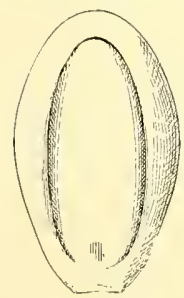

Fig. 1.

olyra latifolia. or at the ends of the branches, the staminate spikelets on slender pedicels or sulsesile on the lower branches or on the lower part of the fistillate branches; pistillate spikelets ovate-lanceolate, nsnally setaceous pointerl, first glume wanting, second glume and sterile lemma membranaceous, nerved, acuminate-setaceous (or long-acuminate only in O. longifolia H. B. K.), the glume longer pointed than the lemma; fruit elliptic, lemma and palea thick, bonyindurated at maturity, the margins of the lemma scarcely inrolled; grain dorsally subcompresserl, enclosed in the lemma and palea; staminate spikelets readily deciduous, much smaller than the pistillate, narrowly lanceolate, glumes and sterile lemma wanting, lemma and palea thin membranaceons, the lemma 3-, the palea 2-nerved. Woody, bamboo-like perennials with ample blades abruptly narrowed into petiole-like lases, convolute in the bud before expanding, the consequent creases permanent and conspicuous in the mature blades. Species about twenty, confinerl to the tropies and subtropics of America except a form of O. latifolia L. or a close ally which is found in South Africa, and a form distantly related to O. micrantha H. B. K. in the Fiji Islands.

The known species fall into three rather well-marked groups.

1. Panicle branches with elliptical or lanceolate, setaceous-pointed, pistillate spikelets above, staminate spikelets below; glumes glabrous or nearly so. 
* Frnit smooth and shining, not pitted.

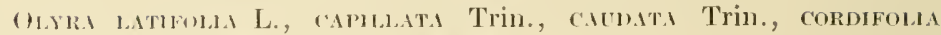

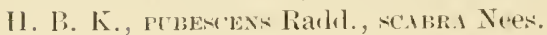

** Fruil not pitted, rothed with thirk silk!l hairs at base and summit, on margins or burk.

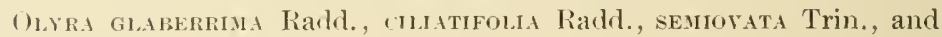
the following:

\section{Oly ra yucatana}

l'anicles contracterl, witen a second one from the npper sheath, $8-15 \mathrm{~cm}$. long, $2 \mathrm{~cm}$. wiele, axis aml rachis scabrous; staminate spikelets on the lower Jranches aml lower part of $m p$ per pistillate hranches, $8 \mathrm{~mm}$. long incluling the setareous tip of the lemma, palea abont 2 mm. shorter; pistillate spikelets 15 to $17 \mathrm{~mm}$. long, the glume and sterile lemma seabrons, 7 -nerverl, s mm. long, and acminate into flexuons setaceons tips as long again in the glume, half as long in the sterile lemma; fruit efliptieal, ofsenrely pointed, $7 \mathrm{~mm}$. long, $f \mathrm{~mm}$. wicke, white and shining or old ivory toward naturity, the lemma silky-pubesent at base and on the margins. (culns tall, slemler; sheaths mostly longer than the internortes, erisp-puberulent, blates 18 to $16 \mathrm{~cm}$. long, one-thirul as wicle, abruptly acmuninte at the alex, trapezoid-truncate at base. Known only from Yincatan.

This species was descrileed and figures by Millspaugh \& Chase (1903, Field (ol. Mus. Bot. : : ti) under the name Olyra semiorata Trin. The examination of 'Trinins' tyje has shown this disposition of the Yucatan

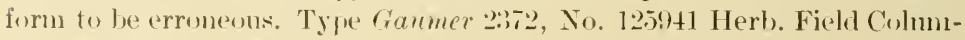
bian Mtsemm. "Common at ('hichankanah, Gaumer 138s, Pocolsoch, Geumer 2:37:."

\section{*** Fruits pitterl.}

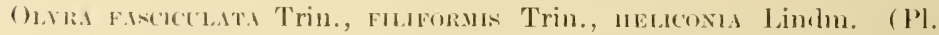
Bulivianae, a Miguel Bander lectae no. 508, distrihuted as O. latifolia belomgs to the latter specie's.)

$\because$ Cpper punicle branches with globose, hispicl-bristly, setaceous-pointed, pistillate spikelets only; lower branches with staminate spiliclets only; rruit pitted.

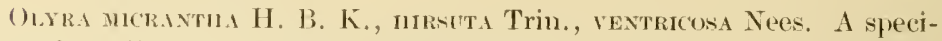
men from "Feejee Islands, Sandalwood Bay" collected on the Wilkes experition 183s-t2 belongs in this group.

B. Upper paniels lranches with oval pistillate spikelets, not pointed, fruit smooth.

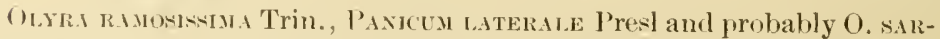
MENTos Doell, form a thirel group with unpointed pistillate spikelets on pedicels searcely clavate, glałrous and unpitted frnit; slender-stemmed freely branching plants with blades and panicles scarcely exceeding $5 \mathrm{~cm}$. long. 
In $O$. ramosissima the staminate spikelets are villons and only on the lower branches of the panicles. Our specimens of P. laterale Presl (Pittier $3641,11008,12058$ ) are destitute of staminate spikelets, but the pistillate spikelets with the first glume wanting, bony-indurated fruit and no stamens, as well as the firm blades abruptly narrowed into a petiole-like base unmistakably place this species in Olyra.

Olyra laterald 's (Presl).

Panicum laterale Presl 1830. Rel. Haenk. 1 : 305. " "Hab. in Peruviae montanis huanoccensibus." The type, in the Presl herbarium in the National Museum at Prag, is labeled "Panicum laterale nor. sp. J. S. Presl" and "Peruano montano oronocciensis." To staminate spikelets are present, the first glume is wanting in the pistillate spikelets, though Presl's description reads: "gluma inferiore brevissima," and again "Gluma inferior minima vix ulla." Judging from the description $O$. sarmentosa Doell is this species or closely allied to it.

Genus LITHACHNE Beauy. 1812, Agros. 185, t. 24, f. 11.

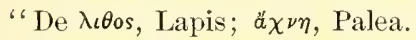

"Culmus ramosus: Axes spicati: Spicae simplices, dissimiles; alia terminali, Locnstis 1-floris, masculis.-Glmmae nullae.-Paleae acutissimae.-Stamina 6 ; alis axillaribus, Locustis 1-floris, semineis.-Glumce herbaceae, acutissimae.-Paleae coniaceo-induratae: infer. truncata, navicularis, gibba. * * * Spec. Olyra pauciflora Lin." [error for Swartz, in the index (p. 168) "Olyra pauciflora Sw. Vid. Lithachne 135 " is given. ]

Beauvois' statement that there are six stamens is an error, due probably to mistaking the separated cells for entire anthers.

Though the genus is based on O. pauciflora Sw. Beauvors does not transfer this name to his new genus; in the index (p. 166) the only species given under Lithachne is axillaris withont reference as to what this name is based on. In the explanation of plate 24 the name Lithachne axillaris is used. Olyra axillaris Lam. 1797 Encyc. $4: 547$ (see below), is the same species as $O$. pauciflora. Sw. and Lam arck cites the latter name as a synonym under his own $O$. axillaris thongh published some years earlier. Beaurois does not cite Lamarck's work though he must have been acquainted with it and his $L$. axillaris is doubtless based on Lamarck's $O$. axillaris.

Olyra pauciflora Sw. 1788, Prod. 21. "Jamaica." The type labeled "Olyra pauciflora Sw. fl. ind. occid. Jamaica Sw." is in the Swartz herbarium at Stockholm.

Trinius (1820, Fund. Agros. 200) includes Lithachne under Olyra, "panicled, or spikelets axillary" covering both in the diagnosis; the gibbous pistillate floret is not mentioned. In 1826 (Gram. Pan. 251) Trinius makes the same disposition of Lithachne; the gibbous character of the floret being mentioned as: "perianthio semiovato, truncato."

Poiret (1823, Dict. Sci. Nat. $27: 60$.) with the spelling "Lithaene" gires a brief description of the genus and species, transferring $O$. panciflora Sw. to this genus, but giving Beanvois as author of the combination. 


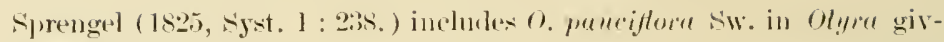
ing Lithachne as synonym.

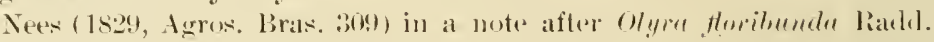
says that this species, which he insertson the anthority of Radelinot having

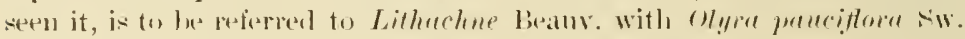
The latter is met inelueled in his Agrestolngia Brasiliensis.

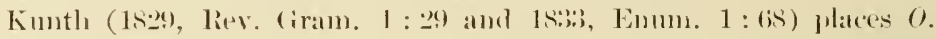
pauciflores. in (Mne withont mentioning the gilshns thoret in either the generic or specific eleseriptien, thongh the axillary panicles are noted. Strephium schral. is given generie rank in the Enmmeratio (p. 70) em-

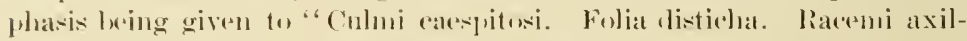

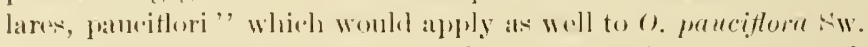

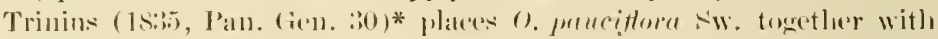

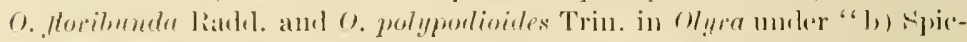

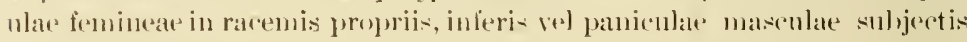
(lithathe P. R.)." The gilhums fruit of () panciflora is noterl.

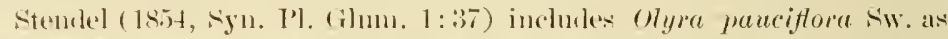
Well as (). Horibunda latuld. and O. polypolioides Trin. in Olyra, anying Trinius' symotical healing givent alluse. The gibluns thoret of 0 . panciHercasis. is not mentioner].

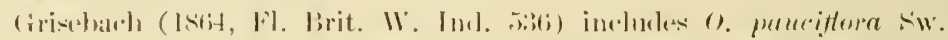

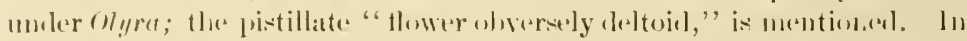

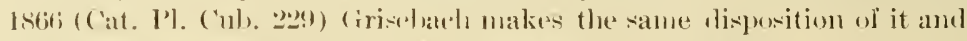

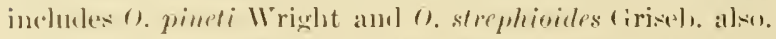

Fournier (1siti, bull. sox. Bot. Belg. 15: f6it, f(6.5) in a paper "sur les

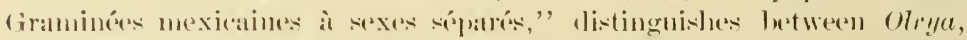

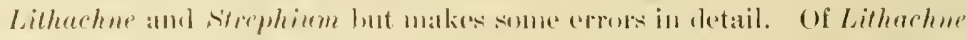
he says the male spikelets aresulerion and the fomale inferiof which serves

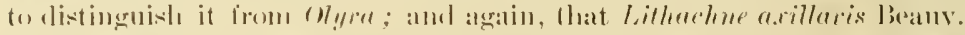

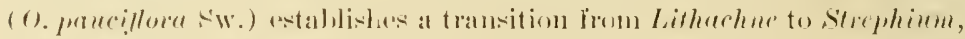

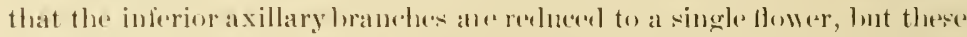

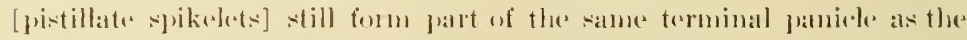

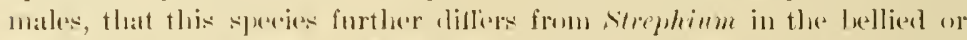

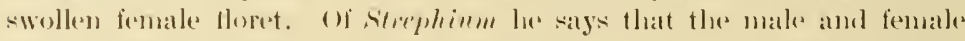
spikelets are in diflerent inflonerenese. But some of these distinctions

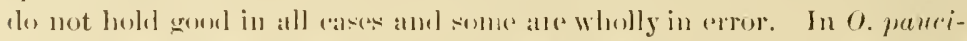

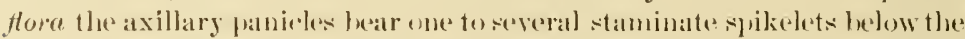
terminal pistillate ole; again we timel no secermens in which pistillate spikelets are truly in the terminal paniele, lut they sometimes appear to be

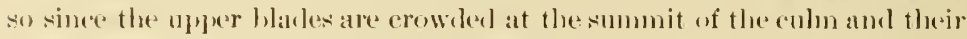
respective axillary inflowecenesescolay the terminal one, which, so far as onr specimens show, is entirely staminate when present, but it is often wanting. As for strephium while the staninate and pistillate sjukededs are almost constantly in distinet racemes we find staminate spikelets (or

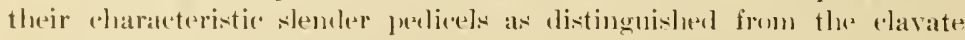
perlicels of the pistillate spikelets) luelow the pistillate spikelets in the

* Mem. Acad. Peter'sb. Ser. VI, $3:{ }^{2} 11$ s. 1435. 
narrow axillary panicles of a Liebmann specimen of $S$. strictiflorum Fourn. cited by Fonmier in lis original description.

Doell ( 1877 in Mart. Fl. Bras. 2: ${ }^{2} 315$ ) inchules all these forms in Olyra, dividing the genus into "I. Acrandrogynae. Panicula terminalis, nonnunquam cum una alterave panicula accessoria laterali. Spiculae utrisque sexus in eadem panicula, femineae pauciores." [It shouli be noted that the lateral panicles of this group are temninal on leafy branches not axillary as in II and III.] This incluites O. latifolia L. and fourteen other species several of which we have not seen, but all (except $O$. sympodica Doell) apparently coming within the genus Olyra as limited above. "II Pleurandrogynae. Paniculae laterales, basi masculae, apice femineae (suprema rarius terminalis et mere mascula.)" This includes O. Alaccida Doell, which we have not seen, and O. pauciflora Sw. "III. Heterogenicae. Paniculae sexu distinctae, monoecae, inferiores mere femineae, nommuquam ad spiculam unicam redactae, superiores masculae. Panicula terminalis, ubi adest et ipsa mascula." A footnote is addel here saying that these characters are those of the genus Strephium which in his opinion has too little to distinguish it. Under this division are O. polypodioides Trin., O. floribunda Radd., and O. nana Doell; O. pineti Wright is arked at the end with the observation that this Cuban species also belongs in this section of the genus. In the description of the latter the gibbons pistillate floret is noted.

Fournier (1881, Mex. 'l. 2:4) recognizes both Lithachne and Strephium as genera, but he gives no generic description and the key is inacurate as regards position of pistillate spikelets in the latter two. (See above under Fonmier, 1876.) Lithache and Strephium are divided on the gibbous floret of the first and linear-elliptic floret of the seconr.

Bentham \& Hooker (1883, (ien. Pl. 3: 1110) include all these forms in Olyra, remarking that Lithachne, Strephium ant Raddia form a section with axillary few-flowered pistillate or androgynons panicles.

Hemsley (1855, Biol. Cent. Am. 3:510) includes all under Olyra, transferring Fournier's Strephium strictiflorum to Olyra.

Hackel (1887, Engler \& Prantl, P'fl. Fann. 2: ${ }^{239}$ ) inclucles Lithachne, Strephinm and Raddia as synonymis under Olyra without sublivisions or sections.

Description.-Spikelets misexnal, mulike in appearance; inflorescence * consisting of few to several small panicles or racemes, solitary or in fascicles of two to four or five, short-excerted from the sheaths, each bearing

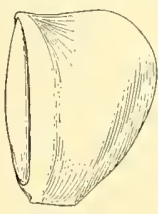

Fig. 2.

Lithachne paucifora. one pistillate spikelet on a clavate pedicel at the summit, and one to several staminate spikelets on slemer podicels, below; a narrow short-exwerted terminal, wholly staminate panicle often present, rarely a fascicle of 2 or 3 such panicles; pistillate spikelets $\mathrm{V}$-shaped owing to the greatly swollen fertile lemma; first glume wanting; second glume and sterile lemma membranaceous, nerved, unequal, longacuminate; froit laterally subcompressed (forning an exception to the tribe character of dorsally eompresseal fruit in Paniceae), lemma and palea thick bony-indurated, the lemma greatly 
swollen or giblons on the back, sin as to appear in sirle view half olberrlatetruncate, the margins inrolled over a narrow palea ; grain laterally sulcompressed, inclesed in the lemma and palea. Staninate spikelets narrowly lanceolate, resuced to the thin-membranareons lemma ambl palea and 8 stamens. Caepitose, herbateous, perentials with simple culms and blades contracted at base and compolnte in the bud as in olyra.

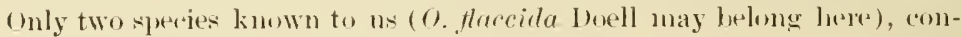
fined to the tropies and subtropics of Americal.

While neither the laterally-compresserl gilbous fruit nor the axillary influresenes alome wonld afford snfficient reason for recognizing Lithachue as a genns, these leeing combines and constant, tugether with a habit distinct from that of Olyra, and the tact that there are no intermerliate species (so far as known), seem to make generic rank the nore natnral disposition of these forms.

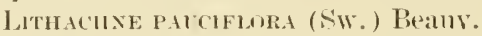

Olyra panciflora S.

Olyra arillaris Lam. 1797. Encye. $4: 547$. "a crienne *** Richaril ( $\mathrm{r} . \mathrm{s})$ " "Lam. illust. t. $751 \mathrm{i}$. 2," is cited. The published date of the part in which this plate necurs is 1820 , but aceorling to sherborn and Woulward * plates 1-100 were publisherl in 1791; $700 \mathrm{in} \mathrm{1797;} \mathrm{901-950}$ in 1819. Evidently some of the plates were printed sonce time lefore they were issued. We late not seen the type lont the plate referresl to alove is momistakable.

Lithachue arillaris Beatry. 1810, Agros. 166 1. 204, 1. 11. No type indicated, presmably based on Olyme arilleris Lam.

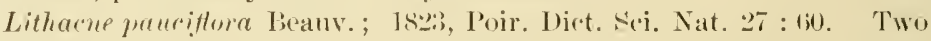
varjeties of this speries have been described ly Kimntze (Rev. (ien. :3 : 2905 ) from Bolivia.

\section{Lithachne pineti ( righth).}

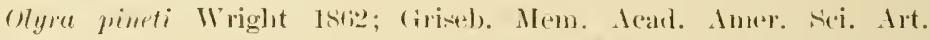

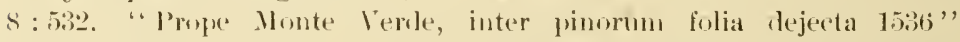
[Wright, ('uba]. The ty]e is in the firicebach herbarimm; a ruplieate in the Gray herbarinn is a tuft of nmmerons very stember enlms. Besides the label the latter weet Jears a slip in Wright's hand "(Olyra l'ineti. (irowing among matises of fallen pine leaves near Mr. Prevals, IJ. V., [Monte V'erile] Ang. "2.:.'."

A delicate species apparently known only from the IV right collection.

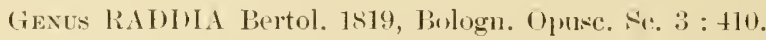

"Flores masenli in racemis distinctis, snperioribus. Calyx miflorns, biglmis, glumis acuminatis, muticis. Corolla nulla. Filamenta brevissima. Antherae lineares longae.

"Flores foeminei in spricis distinctis, inferioribus. Calyx mifloris biglumis, patens, glmua altera longiore, aristata. Curolla biglumis, mutica, stylus simplicisimus.",

*Ann. Mug. Nat. Hist. $17: 542,1946$. 
But one species is given:

"Raddia Brasiliensis.

"Habitat in provincia di Rio Janeiro Brasiliae, v. s."

The specimen was collected hy Radilince Bertoloni states that the specitic name will commemorate the conrageous royage to Brazil of Rarldi to whom the genus is dedieated. The anthor remarks that this genns serves to mite Coix with Olyia.

The whereabouts of Bertoloni's type, if it be in existence, is not known. In the Trinius herbarium is a specimen from Bahia, Brazil, collected by Riedel, labeled Olyra floribunda liaddi by Trinins, and the original of plate 345 in the Icones which agrees well with Bertoloni's description.

Raddi (1829, Agros. Bras. 20) redescribes what is eviclently a specimen from the same collection miler the name "Olyra Horibunda * * * nol,", and gives Raddia Irasiliensis Bert. as a synonym. "Reperitur an radicem Montis Coreovado, nec alibi." [Mt. Coroovarlo is some three miles southwest of Rio Janeiro.] Rarlili's type has not been exmined. Nees says that nothing but the deseription renains, but search among Racleli's Brasilian collections in the herbarium of the botanical garden of Pisa may loring it to light. The two descriptions apply so well to Trinius' specimen that there is no, doult that this species was correctly interpreted by Trinius.

Sprengel (18:7, Syst. 4: Cur. Post. 29) transfers R. brasiliensis Bertol. to Olyra withont comment.

Nets (1829, Agros. Bras. 309) ineludes 0. Horibunde in olypa with the following observation: "De hac specie, arl Lithachuas, Pat. de Beauv, "um Olyra pauciflora Sw. referenda, praeter verba Raddiana nihil superest, quod al feramus." The description states that the pistillate spikelets are in distinct axillary racemes, but does not mention the form of the floret.

Strephium Schracl. 1829, in Nees Agros. Bras. 20:8.

"Spiculae uniflorae, muticae; masch̆lae et foxmineate in distinctis racemis ejusdem plantae. spiculate nusculae: calycis glumae duae, linearilanceolatae; inferior acmminata; corollinat valvulae uullae. Foeminaca spiculae: calycinae glumae dnae, orato-lanceolatae, acminatae; valvulae totidem, cartilagineae. *** Inflorecentia: Racemi, axillares, panciflori. Culmi caespitosi, foliis subdistichis.

"Observ. Genus hocee Olyrae proximum, sed diversum foliatione, spicularum dispositione axillari, foribus masculis superius positis atque glumarum structura et proportione. Echrad."

This is based on a single species, Strephim distichophyllum "Schrad. ined." We have not seen the type of this, but the description applies so well to Olyra polypodioides Trin. that it must be a close ally of that species (the type of which, also from Bahia, Brazil, was examined in the Trinius herbarium at the St. Petersburg Academy of Sciences), as stated by Trinins (1835, Mem. Acal. Petersl). Cer. VT, $3:{ }^{2} 117$ ). Nees description of Olyra Horibunda Raddi (1. c. ) wonld place this species in Strephium instead of in Olyra, but he had not seen O. floribunda and possibly Schrader's genus and species were inserted on Schrader's authority only without 
Inaing been seen by Nees. Trinius' specimen of $O$. floribunda is closely related to Strephium strictiflormm Fourn., thongh much smaller in all its parts, but these are closely eongeneric with O. polyporlioides. This is well

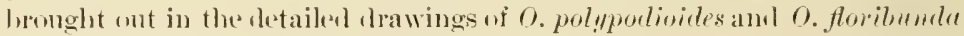
in plate ti, Doell in Mart. Fl. Bras. vol. 2, pt. 2.

Kunth (16:3), Enmm. 1:70) recognizes Strephium as a genus (nee note under Lithachne.)

Trinins (18:35, Pan. Gen. 29)* places O. floribunde Radul. and a new species, O. polypodioides Trin. in Olyza (see note above under Lithachne) ant in the Icones $(1836,13.345)$ the former is figured.

stentel (185t, syn. I'l. (ilnm. 1::66) indules these forms in olypa (see note ahowe under Lithachne).

Wright (1871, Anal. Acad. Cien. Habana 8:20); 1873, Sanv. Fl. Cnl. 19;3) transfers Ligitaria pulchella Grivel, to strephinm with the mark of iloubt.

For the disposition of these forms by Funrnier (1876, Bull. Soc. Bot. Pelg. 15: 4ti.; and 1851, Mex. Pl. 2:t); Doell (187, Mart. Fl. Bras.

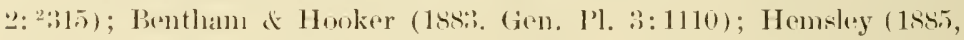
liol. Cent. Am. 3:560), and Hackel (18st, Engler \& Prantl, Ptl. Fam.

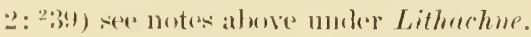

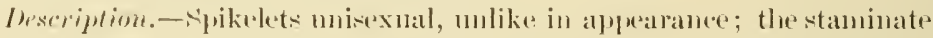
and pistillate in alistinet smatl panicles, the staninate terminal or from

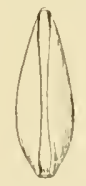

Fig. : 3 .

linteliat prolyporlioirles. the upuner uerles; the pistillate axillary, short-exserted, for-tlowered, usually from the lower moles (al few staminate spikelets sometimes borme below the pistillate spikelets in sirephizm strictifloum); pistillate spikelets lancer)late, first glume wanting, secound glume and sterile lemma menloranacoms, strongly nerved, sulwomal, anduninate;

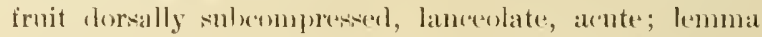
and paleal lony-imburated lout less so than in olyra and Cithachne, the margins flat, nearly meeting over the palea. Staninate spikelets linear-lancenlate. Low canpitose herbacens perennials with simple culms and blates narrowed at the bave, the creases indistimet, usmally eomspicnously distichoms and turned with the surfaces on a single plane. Five known siredes, natives of the troples and salstropies of Ameriua.

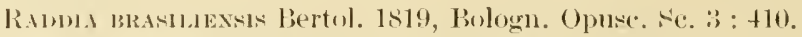

Olyra floribumla Rasld. 18:2:3, Agros. Bras. (Sese above.)

(Dlym bresiliensis spreng. 1827, Nyst. 4: Cur. P'ust. 2!), baserl on Raddia brasiliensis Bertol.

Strephium floribumbum Nees 185t; Stend. Syn. Pl. (ilum. 1 : :36, hatsed (n) Olyore florilonede Radel.

\section{Raddia distichophylla (ichral.).}

Strephium distichophyllum Schrad. 18:9, in Nees Agros. Bras. 2us. "Habitat in sylvis primaevis, prov. Bahiensis al vian Felisherti alil,iqne."

* Mem. Acad. Petersb. Ser. VI, 3: 2117. 


\section{Raddia polypodioides (Trin.).}

Olypa polypodioides Trin. 1s:5, Mem. Ararl. Petersh. Ser. V1. 8: ${ }^{2} 117$.

"Y spl. Bahiens."

Raddia strictiflora (Fourn.).

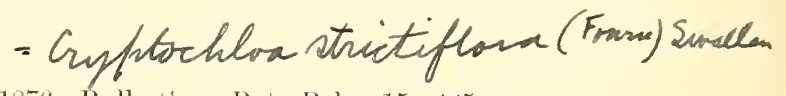

Strephium strictiflorum Fonrn. 1876, Bull. sine. Bot. Belm. 15: 465.

"Arroyo sellero (Karw. [insky] n. 1473 in herb. Petropolitano)."

Olyre strictiflora Hemsl. 1885, Biol. Cent. Am. Bot. :3:510; based on the precerling.

\section{Raddia nana (Doell).}

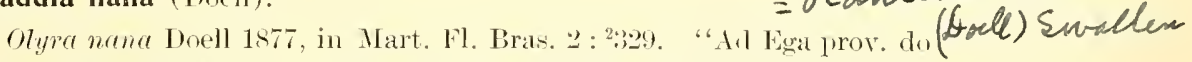
alto amazonas (1lartins)." The type is in the herbarimn of the Botanisches Musemm at Munich.

\section{Raddia concinna (Hook, i. ).}

(Myra roncinna Hook f. 1s!\%, Bot. Mag. IH, 5: : t. 7469. "O. concinna arrived at the Royal Gardens, Kew, in $1891 * * *$ sent by Mr. C. Winkle, from san Jowe in Costa Rica. It Howererl in .January, 1sys."

Olyra symporlica Doell, 1576 in Mart. Fl. Bras. 22: ${ }^{2922} 2$ prolubly belongs in this grouy as snggested ly loell (op. eit. p. :3:9). It seems likely that the "sympolium" he describes is not truly a symporium lut that the culms simulate this habit by a twisting of the internodes, as not infrequently aceurs in this genus and in Lithache.

\section{GENG MNIOCHLOA GEN. NOY.}

Inflorescentia monoina, racenis linis temuibus spicifornibus, alter staminato alter pistillato, summo apici cumi nudi insislentilus constans. spienlae pistillatae 1-florae, olblongo-lanceolatae dorsaliter compressae,

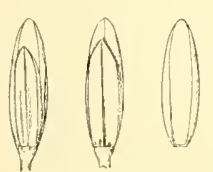

Fig. 4 .

Hniochlou puldiella. solitaris brevisine davellato-pedicellatae, secus rlat elim triangularem tenuem milateraliter dispositae; gluma prima nulla, gluma socumla lemmati sterili aecunans, setis nullis; lenma fertile albo cartilaginiter subindurato, marginibus planis, paleam sinilem anplectens; earyopsis dorsaliter compressa; staminum rudimentis nullis. Epicnlae staninatae pistillatis breviores, glumis lemmatique sterili mullis; lemmati paleaque membranaceis; lemmati 1-nervo, palea "2-nervo, staminilms 8. Gramina perennia hnmilia caespito-a. Cumi fertiles 1-3-nodi, vaginis brevilus laminis carentibus instructi. Culmi steriles eresere, et plerumque duplici orline foliosi ; laminis planis, ze em. longis ant minoribus, ovatolanceolatis, basi abrupte contractis et quasi brevi petiolatis. Trahit nomen

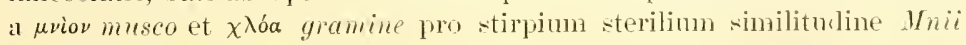
generis cuinsdam musei.

Typus._Digitaria pulchella Griseb. 
Inforescence monoecious consisting of two slender spike-like racemes, one pistillate the other staninate, at the summit of a slender makerl culm; pistillate spikelets dursally compressed, 1-flowered, lanceolate-ollong, solitary on very short clavate pedicels along one side of a slender triangular rachis; first glume wanting, seeond glume and sterile lemma suberpual, mot setacens; fertile lemma white-eartilaginoms submohraterl, the margins that, enfolıling a palea of like texture and equal length; grain lorsally compressed; staminate spikelets smaller than the pistillate, glomes and sterile lemma wanting, lemma and palea membranaceous, effual, the lemma 1-nerved, palea 2-nerved; stanens 3 . Low tuited peremials; the flowering eulms with 1 to 3 norles, the short sheaths lestitute of blasles, distinct from the sterile stems which bear several to many more or less distichons, flat, ovate-lanceulate, blades, less than 2 "m. long, narrower into a petiole-like base. Name from prion moss amel $\chi^{\lambda b a}$ grass, from the resenthlanee of the sterile stems to Mnium a genus of mosies. But two species known, both from (ular.

Type.-Digituria pulchella Grisel).

Mniochloa pulchella (Griseb.).

Digituria pulchella Cirisel). 1866, Cat. I'l. C'ub. 291. "Cuba or. (Wr[ight]:34ts). E[ntemic]." The type in the Grisebach lerbarim at ciöttingen was examined lyy Prof. A. S. Ilitelicork.

Strephium! pulchellum Wright 1871, Anal. Arat. Cion. Habana \& : 202; sauv. Fl. ("ub. 193. 1873. "[3445.] Digitaria pulchella Giris. Crece al lorrle te precipicios en el Yunume de Baracoa."

A lescription follows giving the monoecious clatacter of the inflorescence, a point which seems to have eseaperl Grisebach's notice.

A delicatespecies, flowering enluns filiform, 15 to $25 \mathrm{~cm}$. high, nodes 2 or 3 , at least the lower geniculate, the inper internode and perluncle elongated, sheaths sliglitly inflaterl, 1 to $3 \mathrm{~cm}$. long, racemes ereet or ascending 2 to $: 3.5$ ' 1 . long, the stanninate slightly shorter than the pistillate; pistillate spikelets glabrons, $2.5 \mathrm{~mm}$. long; glume and sterile lemma abont one-fomrth shorter than the glabrous fruit; staminate spikelets $1.5 \mathrm{~mm}$. long, glahoms. Sterile stems sprealing or prostrate, the distichous leaves approximate, the sheaths, at liast the nuer overlapping, ciliate on the margin and at the smmmit, blades firm, 8 to 18 $\mathrm{mm}$. long, 3 to is mm. wide, suluacute, sparsely hairy along the midnerve, pale gren above, lark purplish beneath, mululate on the margins. Known from a single collection, IIright 3448 . In aldition to the type, specinens of this nmmler have been examined in the Gray herbarium and in the Samvalle herbarim in the Estacion Agrommica, santiago de las Vegas, Cuba. The specimen in the Gray herbarim has five flowering culms from the single small tuft. On the sheet is a sljp in Wright's hand "Gram. near Olyra * * not Digitaria, nom. Panicum."

Mniochloa strephioides (Griselı.).

Olyra strephioides Grisel. 1866, Cat. Pl. Cub. 22:!. "Cuba vee. (IVr[ight] 3435)." Type in the Griselnach herbariun at Göttingen. 


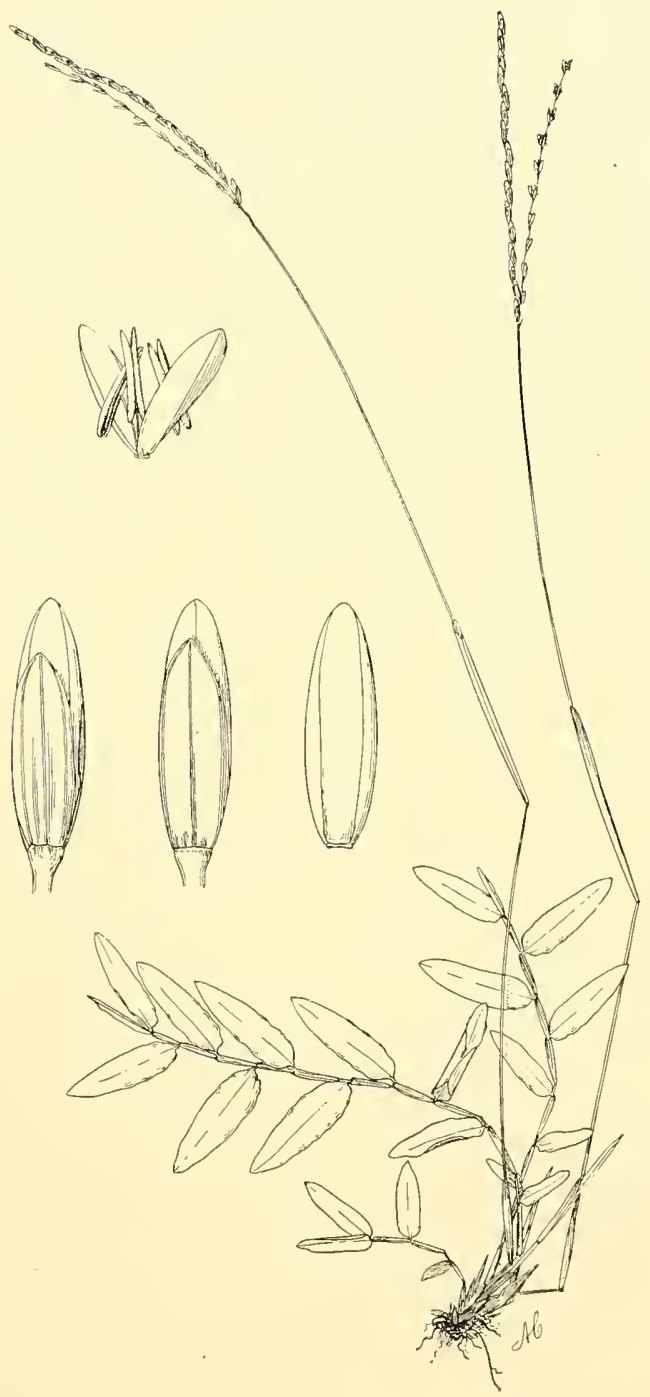

Mniochloa pulchella (Griseb. ) Chase.

Plant, natural size. Staminate spikelet, two views of pistillate spikelet and fruit magnified 10 diameters. 

Grisebach's rescription is inaccurate in regard to the inflorescence, which he descriles as staminate and pistillate mixed, terminal pistillate. The staminate and pistillate racemes are distinct in the type as in the other specimens reen, but the two lie so closely together that they might be mistaken for one muless examined carefully.

Flowering enlms slender 4 to $7 \mathrm{~cm}$. high, equaling or shorter than the sterile stems, the inflorescence short-excerterl, the racemes erect, 1 to 3 cm. long, about equal; pistillate spikelets $3.5 \mathrm{~mm}$. Jong, the glume and sterile lemma glabrons, exceeding the frnit which is entirely clothed with white silky hairs; staminate spikelets scarcely one-half as long as the pistillate, wlal rous. The sterile stems less delicate than in the preceding, blades firmer, pale green, triangular ovate, minutely pubescent on both surfaces, ciliate on the margins. Besiles the type, specimens of Wright 34:35 have been examined in the National Herbarium, Gray herbarium, herharium of Cohmbia Eniversity, and in the Sauvalle herbarium. This species was collected by (aldwell and Baker (no. 7011) at San Diego de los Banos, Cuba, the only known collection since Wright's.

Gents AMPHICARPON, Raf. Jan. 1818, Am. Month. Mag. 2 : 175.

"His [Pursh's] Milium anphicarpon must probably form a new genus Amphicarpon Raf." The toregoing occurs in Rafinesque's review of Pursh's Flora of North America. No generic characters are given and it is erident Rafinesqne had not seen the species upon which he bases his genus, but technically the ahove constitutes priblication.

Mitium amphicarpon Pursh 1814, Fl. 1 : 62. pl. 2. "New Jersey near Egg-Harhour." The plate represents a specimen with a narrow terminal panicle and numerous large spikelets on slender branches from the base of the culm. The type is in the herbarium at Kew. The name "Milimm Amphicarpum" and "Herb. Pursh propr" are written on the sheet, and on the back is written " Y. America, Fred. Pursh."

l'ursh gives a good description of "this singular grass" but his statement: "Flores feminei in scapis rarlicalibns mifloris hasi vaginatis," is inaccurate in that these spikelets are perfect and cleistogamons.

Amphicarmm Kunth 18:!, Rev. Gram. 1 : 28.

"Spiculae biflorae (flore inferiore mipaleaceo, nentro ghumae simillimo), masculae et femineae in earlem planta; has radicates, longe perlunculatae; illae terminales, paniculatae.

"Masc. : Gluma mica (altera inferior nulla), membranacea, concava, mutica. Paleae floris masculi duae, longitudine ghumae, subaequales, chartaceae, concavae, muticae; inferior superiorem binerviam amplectens. *** Stamina tria. Ovarium effetum. Fem: Glmma unica, membranacea, multinervea, concava, mutica, paleis vix brevior. Paleae floris feminei duae coriaceae, acutatae; inferior superiorem binerviam amplectens. ***tamina effeta. Ovarium glabrum. Stigmata duo, terminalia, sub-sessilia, plumosa; *** Caryopsis oblonga, teretiuscula, glabra, libera, paleis inchnsa. Gramen caespitosum. *** Panicula ramis simplicibus; spiculis pedicellatis, racemosis, cum pedicello con- 
tinuis. Pedunculi reminei fasciculati, miflori, raginati; fructiferi subterranei."

But one species is given:

"Amphicarpum Purshii. (Milium anphicarpum P'nrsh. ***),

Although Kunth bestows upon this genus the same name as dir Jafinesque, it does not appear that he knew of the latter's proposed gemms.

Like Pursh in the original deseription of this species, Kunth errs in saying that the sulterranean spikelets are pistillate only, and in this is followed by steutel (1854, syn. Pl. Glum. 1 : :5y and Benthan \& Hooker, (18s3, Gen. Pl. : : 1094). Trinius (18:1, in Sprenge] Neu. Entd., 22 : 50) points out P'ursh's error, statiug that the paniculate spikelets are perfect, dercribing their styles and stignas; and while aplarently not finding stanens in the suluteranean spikelets he argues that these must he perfect since they mature their grains hefore the paniculate spikelets are in anthesis. This latter point cloes not hold good, however, for specimens are common wherein the two forms of spikelets are strietly contemporary. (iray (Ists, Man. bog) gives the first completely arenrate deseription of the genus, "stamens: (small in the ralical flowers)."

Ineseription :-spikelets of two kinds on the sane plant, one in a terminal panicle, perfect but not fruitful, the other cleistogamous on slender leafless liranelues at the base of the culn and sulterranean, sometimes also

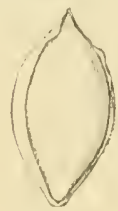

Fig. 5.

Amphicaryon (imphicary)m! from the lowest nodes; first glume of the aerial spikelets varialle in sizs or olsolete, second and sterile lemmal suberpual; lemma and palea indurated, margins of lemma, thin, Hat; frniting spikelets much larger, first glume wanting, second glume and sterile lemma strongly nerver, subrigid, exceelest at maturity by the turgid, elliptic acuminate fruit with much induraterl lemma and palea, the margins of the lemma thin, flat; stamens with small anthers on short filaments. Two -precies of the Atlantic coast plain of the Unitel States.

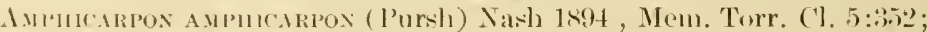
haved on d/ilinu amphicarpon I'ursh.

Besides the -ynomony given above:

"Vilium ciliatum Muhl. 1817. Gram. 77. "Ilabitat in Nova Caesarea." Kunth gives this as synonym under A. Purshii, and is followed by later anthors, but no one states that he has seen the tyle.

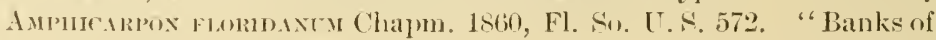
Apalachiewla River, Floriıla."

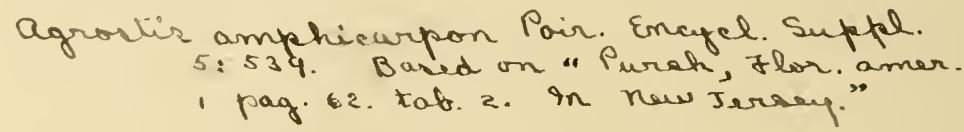




\title{
PROCEEDINGS
}

OF THE

\section{BIOLOGICAL SOCIETY OF WASHINGTON}

\author{
NOTES ON GENERA OF PANICEAE. IV.**
}

BY AGNES CHASE.

The work upon the genera of Paniceae as originally outlined contemplated a consideration by groups. It was the intention of the writer to prepare as a final paper a synopsis of the entire work, in a sequence representing, so far as possible in a lineal series, the natural relationship of the genera investigated. This synopsis with special reference to American genera together with notes on the North American genera are offered in a preliminary way at this time at the request of $\mathrm{Mr}$. G. V. Nash, of the New York Botanical Garden, who wishes to cite the references in his forthcoming treatment of the tribe Paniccae in the North American Flora.

\section{PANICEE.}

Spikelets ideally "-flowered, the terminal floret perfect, the lower staminate or neuter (perfect in Isachne and Dissochondrus), its glume (the sterile lemma) unlike the flowering glume (the fertile lemma) in form and texture and simulating a third empty glume, a membranaceous or hyaline sterile palea (indurated at maturity in Irophorus and in a few species of Panicum) present or wanting, the spikelet or at least the fruit (the fertile floret) dorsally compressed (laterally in Lithachne); fertile lemma and palea alike in texture, indurated, or at least firmer than the glumes and sterile lemma, fimly clasped together (open at the summit in Leptocorymizm and Hymenarhne) inclosing the free grain (in the cultivated Pennisetum americanum the enlarged grain forcing open the lemma and palea), awnless (sometimes mucronate, acnminate-pointed or, in Coridochloa, Alloteropsis, and species of Eriochloa, even short-awned), the nerves obsolete (present in Reimarochloa and Acritochate).

* Notes on Genera of Paniceae 1 appeared in Proc. Piol. Soc. Wash. 19 :183-192. 1906; same 11, op. cit. 21 :1-10.1908; same 1I1, op. cit. 21 : 175-188. 1908. 
In the following synopsis and diagnoses this ideal spikelet is always in mind, the same name being used for corresponding parts, even when the first glume is wanting as in most species of Paspalum or when both glmmes are wanting as in lieimarochloa and in a few species of Paspalum, the scale which appears to be a glmme in the latter case, being the sterile lemma.

The type species of each of the genera here recognized, except Thrasya, Odontelytrum and Dissochondrus, and of most of the generic names referred to synonymy, is represented in the National Herbarium by specimens or in a few cases by spikelets contributed from type specimens.

Frxoptich. KeY.

10 spikelets all alike (the lower of each pair aborted in Echinoluena). 2 a spikelets neither sunken in the cavities of a spongy rachis, nor surronnded by an indurated leat-sheath nor involucre-forn bracts.

- Spikelets not subtender nor surrombled by bristles (sterile branchlets), ( axis of branchlet extending heyond the base of the uppermost spikelet as a point or bristle in Panicum, sul)genus I'anrochretium).

Fruit eartilaginous-indurated, not rigid, papillowe, usually dark colored, the lemma with more or less prominent, white lyaline margins not inpollerl. (Fruit not rigid in Hymenachne, Reimarochloa and in a few species of other gencra, but texture and margin not as above.)

Ppikelets awnless.

Frnit open at lyaline summit . . . 1. Leptocoryphium. Fruit not "se'n at summit.

Lenma boat-sliaped, hyaline margins narrow

Lemma convex with broad liyaline margin.

2. Anthaenantia.

Fruit lanceolate-acmininate; second glume and sterile lemma \#+usually long-silky . . . . . . 3. Ialote Fruit elliptic, pubesence short or none.

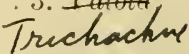

Inflorescence of slemker racemes, digitately or syb-getasn digitately arranged . . . . . . 4. Symthrisma.

Inflorescence a capillary panicle . . . 5. Leptoloma.

Spikelets with slender aws.

Second glume rehnced to a minute scale; sterile lemma with a straight awn ....... 6. Chloridion.

secoml glume and sterile lemma with flexuous or tangled awns . . . . . . . . . . Acritochaete.

Fruit indurated, rigid (or if thin, not hyaline-margined).

Alternatespikelets facing in opposite ways, that is the first glmme altemately extrorse and introrse; inflorescence a solitary, milateral raceme, the margins of the concave rachis partially embracing the subsessile spikelets ............. . . . Thrasya. 
Alternate spikelets not facing in opposite ways (or if so the lower of the pair aborted).

Spikelets (or the primary one of a pair) placed with the back of the fruit turned away from the rachis, usually solitary.

First glume as long as the spikelet or nearly so.

Spikelets in pairs, the secondary usually aborted, sometimes wanting, strongly tuberculate-hispid

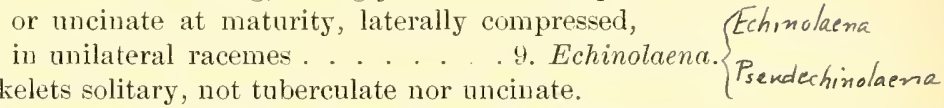
Spikelets solitary, not tuberculate nor uncinate.

Inflorescence a single spike-like raceme; spikelets swollen on the side toward the axis and fitting

T into alternate hollows . . 10. Mesosetum.

* on the side away from the rachis or at least more convex on that side. . . . . 11. Leucophrys.

First glume obsolete or not over $1 / 4$ the length of the spikelet.

First glume and rachilla joint forming a swollen ring-

like callns the spikelet, the glume reduced to an adnate sheath of the rachilla joint; fruit mucronate or shortly awn-pointed . . 12. Eriochloa.

First glume present or wanting but no ring-like callus below the spiliselet.

First glume present; racemes racemose along the main axis . . . . . . 13. Brachiaria.

First glume wanting; racemes digitate or subdigitate......... 14. Axonopus.

Spikelets placed with the back of the frnit turned toward

the rachis of the spike-like racemes, or pedicellate in panicles.

Frnit long-acuminate, scarcely indurated, both glumes wanting; spikelets sessile, solitary in spike-like racemes, these reflexed or verticillate at maturity

15. Reimarochloa.

Fruit not long-acuminate, indurated (if but slightly indurated, both glumes present and inflorescence paniculate).

First glume typically wanting; spikelets plano-convex, subsessile in spike-like racemes .16. Paspalum.

First glume present; spikelets usually in panicles.

A Teither glumes nor lemmas awned.

Spikelet with a single fertile floret.

Second glume and sterile lemma not indurated, like the first glume in texture.

Glumes not equal nor entirely enclosing the rest of the spikelet.

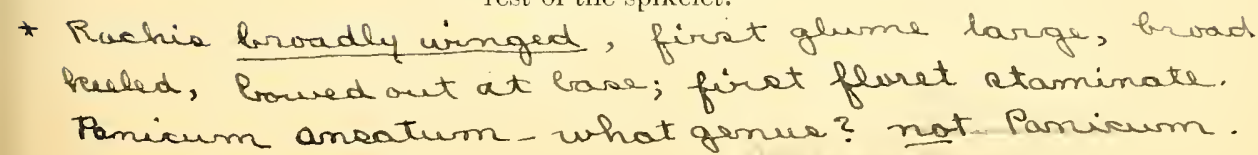


Fruit chartaceons-imlurater the palea enclosed (rarely the tip free).

Second glume not in Haterl-saccate.

Culns not woody nor bamboo like.

Fertile lemma neither witls lateral

appendages nor excavations at base, the inrolled margins clasping the palea; inflorescence typically paniculate.

17. Panicum.

Fertile lemma either with lateral appenulages or excavations at base, the margins usually not inrolled; first glume large; blarles unally contracterl into a petiole-like base . . 18. Ichnanthus.

Culms usually woody, bumbo-like; spikelet: globose, large, the glumes and sterile lemma papery; frnit bony-indurated, a downy tuit at thra alex . . . 19. Lasiacis. second glume inflaterl-salcate, this and the sterile lemma much exceding the stipitate truit . . 20. Sacriolepis.

$=$ Fruit membranaceous, the paleal not inclosed above; rivkelets lanceolate, snbesile in n-nally spike-like panicles. . . . . . . I. Iymenachne. Glumes equal, enclosing the rest of the rlorsally compresserl spikelet; margins of the fertile lemma Hat 2.2. Homolepis. Secoml glume and sterile lemma leatheryindurated; spikelets stipitate. . 2.s. Scutache. spikelets typically with two fertile torets.

Florets alike in form and texture; panicle eompouml. . . . . . . . . . Isachne. Florets mlike, the lower lancenlate, exceeding the upper; panicle racemose.

2.). Heteranthoecia.

A A Glumes or lemmas or both awned, or if shortprinted only, the summit of fertile pralea not encloserl.

Infloresence of unilateral racemes aloner a common axis, never lisitate; glumes ?-lobed (rarely entire) awned from between the lobes; fruit indurater, the palea enclosed at the summit ........... Oplismenus. 
Inflorescence paniculate, or ${ }_{\wedge}$ of slender subsimple racemes, these digitate.

Spikelets never silky-pubescent, nor ciliatemargined, often scabrous or hispid.

Spikelets ovate, not having a callus-like base $\wedge$. . . . . 27. Echinochloa.

Spikelets lanceolate, with a long callus-like

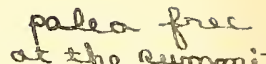
base below the long-awned glumes.

28. Chaetium.

Spikelets silky pubescent or with a conspicuously ciliate margin ; fruit subindurated.

Second glume and sterile lemma 2-lobed, a slender awn from between the lobes; fruit awnless; first glume remote; in-

florescence paniculate . . 29. Sricholaena.
Second glume and sterile lemma not lobed;
fruit awned; first glume not remote; inflorescence of digitately arranged, subsimple racemes.

Sterile lemma and glumes papery, not at all indurated; fruit stipitate.

30. Coridochloa.

Sterile lemma subindurated similar to the fertile lemma . . . 31. Alloteropsis.

Spikelets subtended or surrounded by 1 to many bristles or spines (sterile branchlets), these distinct or more or less connate at base, forming a pseudo-involucre.

Spikelets deciduous, bristles persistent.

Spikelet with lower floret as well as the upper perfect and

with indurated lemma and palea. . . 34. Dissochondrus.

Spikelet with upper floret only perfect.

Sterile palea at maturity becoming cartilaginous and winged, much exceeding the spikelet in width; spikelets secund along the branches of a simple panicle, each subtended by a single viscid bristle.

Sterile palea not enlarged at maturity.

35. Trophorus.

Second glume and sterile lemma very broad, manynerved, the glume saccate, auriculate, the lemma lyre-shaped, indurated on the margins; the spikelet subtended by a single flexuous bristle . 32. Setariopsis.

Second glume and sterile lemma not many-nerved, saccate, auriculate nor lyre-shaped; scbtending bristles 1 to many . . . . . . 33. Chaetochloa.

Bristles falling with the spikelets at maturity (in the cultivated Pennisetum ambricanum the globose grain falls from the usually persistent spikelet, with or without the

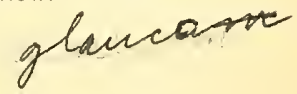
lemma and palea attached). 
Articulation below the spikelet-bearing branchlets.

A single bristle produced beyond the solitary spikelets.

First glome present; seconil glume and sterile lemma acuminate; fruit not acuminate . 36. Chamaeraphis.

First glume usually obsolete, second glume minute, sterile lemma and frnit long-acuminate . 37. Paratheria.

Bristles numerons below each spikelet or cluster of spikelets.

Bristles not uniterl at base, nsually slender, often plumose ........... 38. Pennisetum.

See stapf Haok. Iean 31: Jume 1916

A Bristles more or less united at base into a bur-like pendo-involucre. . . . . . . . 39. Cenchrus.

Articulation at the junction of the primary hranches with the main axis . . . . . . . . 40. Plagiosetum. spikelets either sunken in the cavities of a corky axisor surrounded by a sheath or hy involucre-form liracts.

Spikelets sunken in the cavities of the flattened corky axis, this roc disarticulating at maturity with the spikelets attached.

Spikelets not sunken in a corky axis.

41. Stenotaphrum.

Spikelets in small spikes, these surrounderl hy rigirl sheaths. 42. Terochloa.

Spikelets solitary, subtended by two glume-like bracts, these placed cross-wise to the spikelet* .... . 4. Odontelytrum. is spikelets not all alike.

Plants monoecions or polyganous, that is with the different kinds of spikelets on one plant.

Spikelets all perfect, lunt those of the aerial panicle not perfecting grains; the iruitful spikelets cleistogamons, borne on subterranean branches . . . . . . . 44. Amphicarpon. Spikelets not all perfect.

Spikelets hemaphrodite and sterile.

Spikes several, crowderl on a leaf-like axis . .45. Phyllorachis. Spike solitary . . . . . . . . . 46. Thuarea. spikelets unisexual.

Inflorescence paniculate; fruit bony-indluraterl.

Panicles terminal on culms or leafy branches, pistillate spikelets above, staminate spikelets below, in same panicle . . . . . . . 47. Olyra.

Panicles all axillary or axillary and terminal the terminal when present wholly staminate.

Fruit laterally compressed, conspicuonsly giblıous on upper dlorsum . . . . . . 48. Lithachne.

Fruit torsally compressed, lanceolate . 4!). Raddia.

2 Inflorescence of spike-like racemes.

Raceme solitary; spikelets geminate, a pistillate and a staminate forming a pair . . . 50. Diandrolyra.

* Taken from Hackel's description. We have not yet seen the plant. 
Racemes 2, digitate, one pistillate, the other staminate, the spikelets solitary . . . . . 51. Mniochloa. Plants dioecious. . . . . . . . . 52. Spinifex.

\section{Genus LEPTOCORYPHIUMI Nees.*}

Leptocoryphinm Nees, Agrost. Bras. 83. 1829. Two species are included, L. lanatum Nees, based on Paspalum lanatum H. B. K., and L. molle Nees, the first named being here taken as the type of the genus.

\section{Genus ANTHAENANTiA Beauv.}

Anthrenantia Beaur. Ess. Agrost. 48. pl. 10. f. 7. 1812. Based on a single species, Phalaris villosa Michx. This name is spelled Anthenantia $\uparrow$ by Robert Brown (in Flinders, Toy. App. 2: ${ }^{3} 582.1814$ ) and Athenantia $\uparrow$ by Kunth (Mem. Mus. Paris 2:71. 1815).

Aulaxanthus Ell. Bot. S. C. \& Ga. 1:102. 1816. Two species, A. ciliatus Ell. and $A$. rufus Ell, the first named of which is here taken as the type, are included. The type of $A$. ciliatus, in Elliott's herbarium, is Anthaenantia villosa (Michx.) Benth. Elliott refers "Phalaris villosa? Michx." to A. ciliatus. With the later fascicles of Elliott's work an illustration of $A$. rufus (pl. 6. f. .1), was given, but since this was not published until 1821 the first species published under the genus is taken as the type.

Aulaxia Nutt. Gen. Pl. 1:47. 1818. This is based on Aulaxanthus Ell., Elliott's description, slightly altered, being used and his species cited. Steudel (Nom. Bot. ed. 2. 1:171. 1840) spells the name Aulaxis.

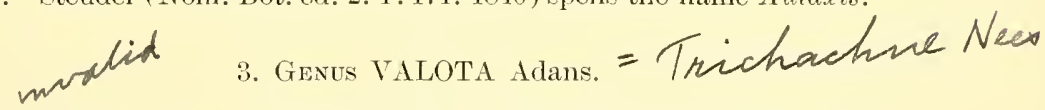

Valota Adans. Fam. Pl. 2: 495. 1763. This genus is established by a reference to "Sloan. t. 14. f. 2." This figure identifies the genus with Andropogon insulare L. (Syst. Nat. ed. 10. 2:1304. 1759). The type of the latter in the Linnaean Herbarium is from Jamaica, sent by Browne. After his diagnosis Linnaens cites "Sloan. jam. t. 14. f. 2." Stendel (Nom. Bot. ed. 2. 2:744. 1841) spells the name Trallota.

Acicarpa Raddi, Agrost. Bras. 31. pl. 1. f. 4. 18:3. This is based on a single species, A. sacchariflora Raddi, the figure and description of which inentify it with Valota insularis. Raddi also cites "Sloan. H. jam. I. p. 43. t. 14. fig. 2).'”

Trichachne Nees, Agrost. Bras. 85. 1829. Six species are included in the genus, T. insularis Nees which is taken as the type, based on Andropogon insulare L., T. sacchariflora (Raddi) Nees, which we now know to

* The group containing the first five genera here given was earlier discinssed and the fruit of the type species figured (Proc. Biol. Soc. Wash. 19:183-192. 1906). Only a summary of that discussion is here given, with such additional knowledge as has been gained.

+ These misspellings or changes of spelling are here given only because these names have found their way into synonymy, hence must be accounted for. 
be synonymous with the first, and four new ones, $T$. recalva, $T$. tenuis, T. velutina and $T$. ferruginea.

Since the notes on Valota were published* Prof. A. S. Hitcheock has examined the types of $T$. tenuis and $T$. recalea in Nees' herbarimm at Munich, and duplicate types of $T$. ferruginea and $T$. velutina in the Trinins Herbarium. Trichachne recalva is seen to be allied to I'. Pittieri (Hack.) Chase, while $T$. fermgined and $T$. velutina approach Symtherisma through S. adusta. Trichachue tenuis Nees, upon which Kunth based Panicum tenerrimum (Rés. Gram. 1:39. 1829) is most nearly allied to $V$. insularis, but has much smaller spikelets with less copious and shorter hairs. None of these species are the one referred to $\dagger$ as represented in American herbaria by Nealley's Texas collections and passing under the name of Panicum tenerrimum Kunth. This very distinct species was collecterl in the summer of 1910 by Prof. A. S. Hitchcock, and is described below:

\section{Valota Hitchcockii sp. nov. = Truchachne}

Plants perennial, in dense clumps; culms erect, very slender, 30 to 50 $\mathrm{cm}$. high, sparingly branching from the lower nodes, glabrous, usually very leafy, the lower nodes ascending-villous, the upper glabrous; sheaths about as long as the internodes or overlapping, the lower silky-villous, the middle and upper with a few, scattered, delicate hairs or glabrous or silky-ciliate only; ligule membranaceous, scarcely $0.5 \mathrm{~mm}$. long, continued as a brown scarions margin down the sheath; blades ascending or erect, flat, 2 to $4.5 \mathrm{~cm}$. long, 2 to $2.5 \mathrm{~mm}$. wide, scarcely narrowed to the base, glabrous on the lower surface, minutely puberulent or glabrous on the upper, usually with a few long hairs near the base, and with a thin, white, cartilaginons margin ; panicles comsisting of few to several ascending racemes rather distant along a slender, glabrous axis, the rachises -lender, 3-angler, the spikelets mostly in pairs, one short-pediceled, the other on a perlicel alout as long as the lower spikelet, thus forming slender racemes, the spikelets scarcely imbricated; spikelets whitish or purplish, 2.5 to nearly $3 \mathrm{~mm}$. long, $0.7 \mathrm{~mm}$. wile, or with the liairs expanded about 1.2 $\mathrm{mm}$. wide; first glume less than $\frac{1}{5}$ the length of the spikelet, obtuse, glabrous; second glume and sterile lemma equal, strongly 7 - to 9-nerved, the internerves and margins densely silky hairy, the hairs at first appressed, at inaturity spreading and matted, the spikelets often matted together by the tangled hairs; fruit 2.1 to $2.2 \mathrm{~mm}$. long, $0.6 \mathrm{~mm}$. wisle, abruptly short-acuminate, brown, the broad, white, hyaline margins of the lemma nearly covering the palea except at the base:

Type collected June 24, 1910, on dry prairie soil, San Antonio, Texas, hy A.S. Hitcheock (no. 5:329).

Valota Mitchcockii is most nearly related to I. saccharata (Buckl.) Chase, from which it is distinguished by its lower stature, short blades, short racemes of smaller spikelets, the sterile lemma densely hairy on all the internerves, while in $V$. saccharata the middle four internerves are

* Proc. Biol. Soc. Wash., 19:186. 1906

† p. cit. p. 188 . 
glabrons, the hairs of the lateral internerves and margins and of the second glume being also much longer than in V. Hitchcockii; the fruit of the latter is much smaller, less acuminate and the lemma more broadly margined than in $V$. saccharata.

This species is known only from Texas. It was also collected by G. C. Nealley, at Sanderson, Pecos County, in September, 1892, and at Del Rio, October, 189., both collections being distributed as no, 109 .

Until the South American species referable to Valota are better known the transfer of Nees' species of Trichachne to this genus is deferred.

\section{Genus Syntherisma Walt. = Digitana Heist}

Sanguinella Gleichen, Mikrosk. Untersuch. 4. pl. 8. 1764. This includes a single species with a phrase name which is not directly associable with a previously published binomial, hence the genus is not technically published. The plate is a crude colored representation of Syntherisma sanguinalis.

Digitaria Haller, Stirp. Helv. 2:244. 1768, not Adanson, 1763. Haller inchudes two species, the first of which is Linnaeus' Panicum sanguinale, this name, however, being omitted and Linnaeus' diagnosis used instead as a phrase name.

Syntherisma Walt. Fl. Carol. 76. 1788. Three species are included, the first of which, S. praecox Walt, is taken as the type. Thongh there is no specimen of this now in Walter's herbarium,* there is little doubt that it the same as Panicum sanguinale L. as stated by Michanx $\uparrow$ and by Elliott. $\ddagger$

Gramerium Desv. Opuse. 61. pl. 7. f. 1. 1831. This includes a single species, G. concolutum Desv. We have not seen Desvaux's specimen but the description and figure apply well to the South American allies of Syntherisma adusta (Nees) Chase, and may possibly refer to a small specimen of that species itself.

Sanguinaria Bubani, Fl. Pyren. 4: 256. 1901. Four species are included, the first of which, here taken as the type, is $S$. nevenarae Bub. From the synonyms and illustrations citer this is seen to be $S$. sanguinalis.

\section{Genus LEPTOLOMA Chase.}

Leptoloma Chase, Proc. Biol. Soc. Wash. 19:191. 1906. Based on Panicum cognatum Schult., L. cognatum (schult.) Chase.

\section{Gexus CHLORIDION Stapf.§}

Chloridion Stapt in Hook. Icon. Pl. $27:{ }^{2}$ pl. 2640. 1900. A single species, C. cameroni Stapf, from "British Central Africa: *** Namasi,

* For an account of the grasses in Walter's herba rium see Hitchcock, Sixteenth Ann. Rept. Mo. Bot. Gard. 44. 1905.

+ Fl. Bor. Amer. 1 : 45.1808.

\$ Bot. S. C. \& Ga. $1: 131.1816$.

S.It is intended to discuss in detail this and other extra-American genera in a later paper, when the spikelets of the type species will be figured. 
Cameron, 15 (coll. of 1599)," is included in the genus. The type has not been examined but the description and plate identify the species with the following.

Stereochlaena llack. Proc. Rhorlesia Sci. Asroc. $7:{ }^{2}$ 65. 1908. One species, S. Jeffreyssii Hack., "Bulawayo, Maio, 1907, leg. Jeffreys, no. 46, 8.." Professor Hackel kindly sent spikelets of the type for deposit in the National Herbarimm, and stated in a letter that Stereochlaema " is identical with Chloridion Stapf, Hook. Ic. 2(ito (1900)."

In this genus the fruit is cartilaginons-indurated, brown, papillose, the margins of the lemma white and hyaline, as in the other genera of this gromp. The inflorescence consists of few to several slender racemes, digitate at the summit of the culm; the short-pediceled, lanceolate, spikelets are in pairs, the first glume is wanting, the second a minnte scale; the sterile lemma is attenuate into a slender scabrons awn, 4 or 5 times longer than the boty of the spikelet, and encloses a minute cleft palea. Stapt says "Chloridion might be lescribed as a Digitaria in which the lower ghme is entirely suppressed and the upper reduced to a scale, whilst the lower (barren) valve runs ont into a fine bristle-like awn."

\section{GENes ACRITUCHAETE Pilger.}

Acrituchaete I’ilger in Engler, Bot. Jahrr,. $82: 5 \%$; 190:2. The genus is basecl on one species, A. Tolkensii I'ilger (op. cit. 54) "Ost-Afrika, am Kilimancischaro, in (irütelwald oberhalh) Marangu verbreitet, 2100 $\mathrm{ml}$. s. m. (Volkexs 1.1275.$)$, A portion of a raceme from the type specimen was kinully sent to the National Herbarium by Dr. I'ilger.

This genus like the preceding is very mlike any known American grass. In Acritochaete the scarcely indurated fruit is more like that of Reimarochloa or IIymenachne than like that of the preceding genera in texture, lut the broal, white, thin-nenbranaceous margins of the kmma are like those found in this gromp. Chloridion is evidently related to Syntherisma, and Acritochaete is more nearly related to Chloridion than to any other known genns. The indloreseence consists of a few slender erect, listant racemes; the solitary, short-perliceled, lanceolate spikelets in two rows on one sicle of the slenter raceme; the first glume is reshees to an obscure scale, the second glume and sterile lemma are attenmate into long, slender, more or less twisted and irregularly flexnons awns several times longer than the body oi the spikelet, the awns of the several spikelets more or less entangled.

\section{Genus THRASTA H. B. K.}

Thrasya H. B. K. Nov. Gen. \& Sp. 1 : 120. pl. 39. 1816. This is based on a single species, T. paspaloides (op. cit. p. 121). "Crescit in calidis, subinundatis insulae Orinocensis Panumana, inter vicos Atures et San Borja." The type has not been examined nor has any specimen of this species. The generic characters here given are based upon a study of specimens of Panicum thrasyoides Trin. (Thrasya hirsuta Nees) and $P$. 
petrosum Trin. and the other two species here listed. Judging from Kunth's description and plate 34, and allowing for evident error in each, Thrasya paspaloides is closely related to $P$. thrasyoides Trin. Kunth places his Thrasya as the last genus of "Sectio I. Paniceae" (about the equivalent of our subfamily Panicoideae) immediately following Manisuris granularis (Hackelochloa). He diagnoses Thrasya as being 2-flowered, having two glumes, "superior profunde bipartita," the halves aristate below the apex, "inferior [gluma] integra mutica." The male floret is said to lıave but a single palea [both valves of a floret being termed paleae]. From dissections of spikelets of $P$. thrasyoides and from plate 39 the following conclusions are reached: Kunth overlooked the small, hyaline first glume (which in $P$. thrasyoides is more or less buried in the cleft of the sterile lemma and might easily escape notice); his entire, awnless, lower glume is the second glume; his deeply divided upper glume, the sterile lemma, the aristae of the halves being not awns (prolongations of fibrovascular bundles) but stiff, quill-like hairs; the single palea of the male floret is the sterile palea. It is strange that Kunth, failing to note the first glume, did not, nevertheless, count it as obsolete, since failing to do so, and counting the second glume as the first, he describes a spikelet in which the scales are not distichous, for his male floret is immediately above the (supposed) second glume instead of on the opposite side above the first. The margins of the sterile palea (in the allied $P$. thrasyoides) are so narrow and so readily torn from the hyaline middle portion that the fact that they tumed toward the supposed second glume might escape observation. Kunth describes this "flosmasculus" as "subtrinervia" being a palea it has no midnerve, where Kunth evidently looked for one. But even if this [supposed] incongruous structure of the spikelet escaped him (if it did escape him ) Kuntl considered his Thrasya a most curious grass. He states that though it resembles Paspalum platycaule in habit, the structure of the flowers is so singular as to be widely different from that of all known genera. Nees (Agrost. Bras. 93. 1829) in his diagnosis of Thrasya notes a minute, scale-like inferior glume "(a cl. Kunth neglecta.)" 'The further important character that Kunth neglected, that is the alternately reversed position of the spikelets on the axis, Nees takes note of in his specific description of Thrasya hirsuta (based on Panicum thrasyoides Trin.), though Trinius failed to do so.

Description.-Inflorescence a single, terminal, more or less arcuate, spike-like raceme; spikelets apparently subsessile and solitary, in a single row on one side of a channeled, more or less winged rachis (the wings partially embracing the row of spikelets), but actually in pairs (the spikelets of each pair back to back) the pedicel of the primary spikelet adnate to the midnerve of the rachis* (the spikelets spreading from the

* To account for the alternation in position of spikelets, this was the interpretation arrived at by the writer from an examination of $P$. thrasyoides and $P$. petrosum, but I should not have ventured to give it at this time had $I$ not found that it is the conclusion. of Prof, Hackel (Oesterr. Bot. Zeitschr. 51:368. 1901) in the case of Panicum campylostachyum, in which species the paired arrangement is more erident than in $P$. thrasyoides and $P$. petrosum.

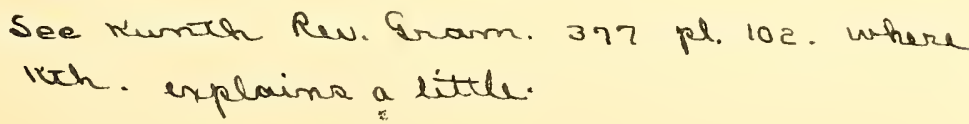


rachis at an angle of abont 45 degrees), alternate spikelets placed with the back and alternate sprikelets placed with the face toward the rachis (that is, the first glume alternately introrse and extrorse), a short callus below the spikelet; first glume minute, often hyaline and nerveless; second glume membranaceous, shorter than the spikelet; sterile lemma subindurated, thinner down the middle and early splitting to the base (the margins of the split rolling inward) or deeply sulcate only, the sterile palea nearly as long as its lemma, the nerves and margins firm, the broad internerve very thin, a staminate flower present or wanting; fruit oblong-elliptic, subacute, the lemma and palea cartilaginons-indurated, papillose, the summit of the lemma often elothed with stiff hairs, the thin margins flat, more or less pubescent. Slender, branching perennials, with narrow leaves, the genus confined to the tropies of the mainland of the western hemisphere.

The strictly racemose inflorescence, the alternation in the position of the spikelets, the snljinlurated, split or deeply sulcate sterile lemma, and the cartilaginous (not chartaceons) indurated lemma anel palea, the thin margins of the lemma Hat, taken in eombination, are here nsed to distinguish Thrasya from Panicum and Paspalum. Thrasya approaches Paspalum throngh Thrasya cultrata and Panicum campylostachyum (in which the fruit is not hairy at the simmit) on the one sicle and Paspalum monostachyum H.-B. K. V'arey (in which the slightly indurated sterile lemma is somewhat sulcate and readily splits in dissection, and the firm margins of the papillose fertile lemma are not in rolled), on the other side. In the latter species, however, the paired spikelets are in two rows, and not in the alternately reversed position of those of Thrasya. If we conceive of a genus as bounded by an orbiculate line in places farther from, in places nearer to, the center (the species conceiver to be the type of the genus) we have Paspalum monostachyum close to the line in one circle and Panicum campylostachyum and Thrasya cultrata close to the line in the adjoining one, the theoretical common ancestor of both long extinet. In such cases of extra-generic athity it seems to be the nearest approach to a natural arrangement if we place the anomalous species in the genus to the members of which it is on the whole most nearly allied. And Paspalum monostachyum finds its nearest allies in Panicum unispicatum Sicribn. \& Merr. and a few other species of the section IIarpostachys or Dimorphostachys of Paspalum.

The following species belong to this genus:

Thrasya paspaloides H. B. K. Nov. Gen. \& Sp. 1:121. pl. 39. 1816. (See above.)

Panicum thrasya Trin. Mém. Acad. st. Pétersb. VI. Sci. Nat. $3:{ }^{2} 228$. 1834. Based on T. paspaloides H. B. K. Only the Humboldt and Bonpland specimen is mentioned. It is possible that this species has not been collected a second time.

\section{Thrasya thrasyoides (Trin.).}

Panicum thrasyoides Trin. Gram. Pan. 126. 1826. "Brasil. (LangsDoRfF)." The type specimen, in the Trinius Herbarium, is labeled 
"Panieum thrasyoides m. nbique in eampis siceis, Brasiliae crescens, leg.

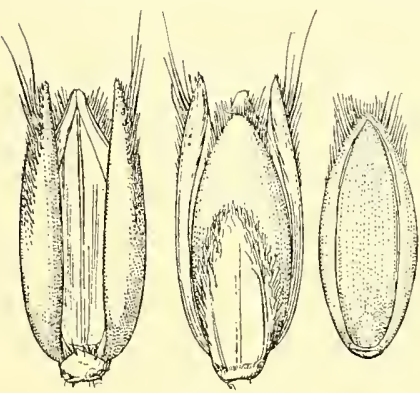

Fig. 1.

Thrasya thrasyoides.

(Two views of spikelet and fruit $\mathrm{x} 10$ diam.) mense Dec. 18:4. cl. Langsdorff."

Thrasya hirsuta Nees, Agrost. Bras. 94. 1829. Based on P. thrasyoides Trin. Nees distinguishes between this and $T$. paspaloides, a speeimen of the original collection of which he examined in the Willdenow Herbarium. We take it on his authority that the two are distinct. So far as we know they have not been united, but they are elosely allied and it seemed possible that Kunth's erroneous deseription might have led to failure to recognize his speeies.

\section{Thrasya petrosa (Trin.).}

Panicum petrosum Trin. Gram. Icon. 3: pl. 280. 1836. Trinius states that the illustration is "ad specimen Brasilianum." The type specimen, in the Trinius Herbarium, labeled "Panieum petrosum n. Cuyaba tebr. 1827," was probably collected by Langsilorff."

Tylothrasya petrosa Doell, in Mart. Fl. Bras. 22 : ${ }^{2} 295$. pl. 37. 1877. Based on Panicum petrosum Trin. Doell bases his genus Tylothrasya on this speeies, the basal callus being the character by which he differentiates it from Thrasya H. B. K. Thrasya thrasyoides, howerer, has this callus though it is less pronounced than in $T$. petrosa. Bentham (Linn. Soc. Journ. Bot. $19: 42.1881$ ) misspells the speeific name "petraeum."

Thrasya cultrata (Trin.) Nees, Agrost. Bras. 94. 182\%.

Panicum cultratum Trin. Gram. Pan. 126. 18:6. "Brasil (LaxgsDorff)." The type speeinen, in the Trinius Herbarium, is labeled "Panicum cultratum m. In graminosis, m. da Congonhas, Brasil. leg. mense Jan. 18.5. el. de Langsdorff. Thrasya cultrata N. ab Esenb." Above this the name "cultratum" had been written and erossed out, apparently by Trinius himself, and " monostachyum Hb. Kth." added. In his later work, "Panicearum Genera" (Mém. Aead. St. Pétersb. VI. Sci. Nat. 3: ${ }^{2} 28.1834$ ) Trinius gives $P$. cultratum as a synonym of $P$. monostachyum.

\section{Thrasya campylostachya (Hack.).}

Panicum campylostachyum Hack. Oesterr. Bot. Zeitsehr. 51 : 367. 1901. "Costarica; in savannis ad Cañas Gordas leg. Pittier, nr. 11012 et 11018." The type (no. 11012) is in Hackel's herbarium, a duplieate is in the National Herbarium.

This and the preceding species differ from the first three here listed in the lack of the quill-like hairs on the halves of the split sterile lemma, and also on the summit of the fruit. 
There are several South American species, Panicum Schumannii Pilger among them, at present insufficiently known to us, which belong in this genus.

\section{Gexus ECHITOLAENA Desv.}

Echinolaena Desv. Journ, de Bot. Paris $1: 75$. 1813. This genus is based on a single sprecies, E. hirta Desv. (1. e.) "Habitat in America equinoxiali." The type specimen, bearing in lessanx's handwriting the nane and date as published, is in the herbarium of the Musémm d'Histoire Naturelle at Paris.

Echinolaena was recognized ats al gemus by Kinnth (H. B. K. Nov. Gen. \& S1. 1:11S. 1816, Rév. Gram. 1:5t. 1829, and Enum. Pl. 1:171. 1833), and by Trinins in his earlier work (Gram. Pan. 75. 18:6), thongh later (Mén. Acar. St. Pétersb. VT. Sei. Nat. : : ${ }^{20}: 30$. 18:34) he includes it under his section IIarpostachys of Panicum. Nees (Agrost. Bras. 127. 182y) nake- it a section of Punirum. Stendel follows Trinius' later disposition of the genus, as whes Doell (Mart. Fl. Bras. $2:{ }^{2} 179$. 187t). Bentham (Lim. Soc. Journ. Bot. 19:50. 1881) maintains Echinoleena as a genus becanse of its having "the rigid single spike of some (hlorideate," and in the Genera l'lantarmm (Benth. \& Hook. (ien. Pl. :: : 1107. 188:3), also, he gives it generic rank. Hackel (Engler \& Prantl, Pflanzenf. :2 : ${ }^{2} 35 \overline{.}$ 1887) rednees it to a section of Panicum.

Description.-Inflorescence of one dense and spike-like, or several rather loos racemes; spikelets in pairs, face to face, the primary short-pediceled and perfect the secondary subsessile, abortive (sometimes developed, rarely wanting), the back of the primary spikelet turmer toward the axis (that is the back of the fruit turned from the axis), in two rows along one side of a that rachis and more or less divergent from it; fertile spikelets laterally subcompressed, echinate, at least at maturity; glumes broal, firm, amminate-pointer, one or both echinate at maturity, the first straight and as long as the spikelet or longer, the second boat-shaped or becoming rentricose; sterile lemma broad, acuminate, enclosing a nearly equal sterile falea and usmally a staminate flower; fruit indurated, less so than nsual in Prnicum, plano-convex, elliptical, the margins of the lemma flat or inrolled at the smmmit only, a minnte menbranacesus wing or spongy thickening on either side at base. Freely branching, more or less decumbent or creeping herhs, the type species confined to the South Anerican tropies, another of wilespread tropieal distribution and a third of IIadagasear.

The statement made by Bentham (Benth. \& IJook. Gen. I'l. 3: 1107. 188:3): "rhachi spice rigida ultra spicnlas producta," and which appears from the Conspectus (patge 1078) to express his chief reason for maintaining Echinoluena as a valid genus, is found to be erroneous. The mpermost spikelet in $E$. scabra (E. hirta), the one species Bentham admitted to the gemns, (as well as in E. polystuchya) is strictly terminal, the rachis not at all produced beyond its insertion. This uppermost spikelet is solitary and usually erect, and the first glume is long-acuminate 
(longer than in the other spikelets) and has mnch the appearance of a hirsute prolongation of the rachis. The characters to which we here give chief weight as generic are the strictly racemose inflorescence, the paired spikelets face to face (exactly the opposite arrangenent to that in Thrasya), the lower or secondary spikelet of the pair abortive or usually so, the fertile spikelet with its back to the axis (as in Brachiaria), the long first glume, and the fruit less indurated than in Panicum.

Raceme solitary, terminal on the culm or branches; second glume boat-shaped only . . . . . . . . . . . E. inflexa.

Racemes several, erect, distant along a common axis; second glume becoming ventricose and uncinate-spiny at maturity . - E. polystachya.

\section{Echinolaena inflexa (Poir.).}

Cenchrus inflexus Poir. Encyc. Suppl. $6: 50.1804 . \quad$ "M. Richard l'a recneillie à Cayenne. (V. s. in. herb. Jussieu \& Lam. )" The type specimen in the herbarium $r$.e Muséum at Paris was examined by Prof.

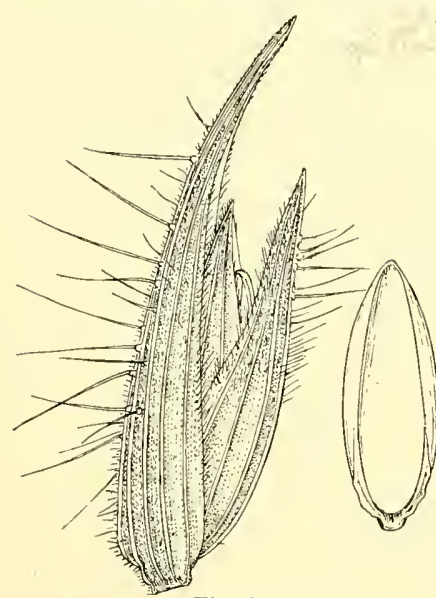

Fig. 2.

Echinolaena inflexa.

(Spikelet and fruit $\times 6 \frac{2}{3}$ diam.) Hitcheock and found to be the same species as the type of Echinolaena hirta Desv. in the same herbarium. Trinius (Gen. Pan. 75. 1826) also referred $C$. inflexus Poir. to E. scabra H. B. K. Poiret observes that he finds no involucre, that the species may belong to another genus, and that it deserves further study.

Cenchrus marginalis Rudge, $\mathrm{Pl}$. Guian. 19. pl. 25. 1805. No locality nor specimen is cited. The type has not been examined but the plate and description identify the species.

Echinolaena hirta Desv. Journ. de Bot. Paris 1 : 75. 1813. (See above.)

Echinolaena scabra H. B. K. Nov. Gen. \& Sp. 1 : 118.pl. 38.1816. "Crescit in ripa umbrosa Atabapense juxta vicum San Balthasar et rupem Kemarumo. (Prov. de la Nueva Guayana.)" The type specimen has not been examined but the plate and description identify the species.

Panicum echinolaena Nees, Agrost. Bras. 129. 1829. Nees divides the entire species into three varieties, $\alpha, \beta$ and $\gamma$ and cites "Echinolaena scabra $\mathrm{H}$. et $\mathrm{K}$." as a synonym without indicating to which variety he considers it synonymous. Since he also cites specimens we can not consider $P$. echinolaena a change of name only. "Var. a et $\beta$ in Brasilia meridionali. (Sellow.) Vidi in Herb. Reg. Berol.)-Var. $\gamma$ in campis siccis ad Tanbaté nec non Sabara, provinciarum S. Pauli et Minarum * * * (Martius)." The specimens referred to as $a$ and $\beta$ have not been examined. The Martius specimen, the type of var. $\gamma$, in the Munich 
VI. Sci. Nat. $3:{ }^{2} 240$. 1834) places $P$. uncinatum in the section Brachiaria.

Kunth (Rév. Gram. 1:54. 18:9) doubtfully refers to Echinolaena his own E. polystachya, together with Panicum nemorosum Sw., P. naviculare Nees (both of which belong in Irhnanthus) and P. brachystachyum Nees and $P$. procurrens Nees. In his syuoptical heading the character "gluma superior echinato-glochidata" would exclude all but E. polystachya. In the Enumeratio (Enum. Pl. $1: 173.1833$ ) Kunth again doubtfully includes these species and adds Panicum loliaceum Bert., probably referable to Ichnanthus.

While the uncinate and ventricose second glume of the mature spikelet of this species makes it look very different from spikelets of E. inflexa, the paired spikelets, the primary fertile, the secondary abortive or rudimentary, placed face to face, the back of the primary one turned toward the rachis, and the essentially like structure of the spikelet to that of $E$. inflexa show the two species to be congeneric. The second glume becomes indurated and spiny only as the spikelet nears maturity; the immature spikelets resemble those of $E$. inflexa. The sterile spikelet is often reduced to a mere rudiment, is sometimes wanting, and is rarely developed like the primary spikelet. In the fifty specimens of this species in the National Herbarium none are found without some of these sterile spikelets in the racemes.

From the description, Echinolaena madagascarensis Baker, a species which we have not seen, appears to belong unmistakably to this genus.

\section{Gexus Mesosetuli Steud.}

Mesosetum Stend. Syn. Pl. Ghum. $1: 118.1854$. This is based on a single species, M. cayennense Steud. (1. c.) "Leprieur legit in Cayenne." The type specimen, labeled "Mesosetum cayennense Steud. Cayenne. Leprieux, 1825," in the Stendel Herbarium at Paris, is found to be the same species as Panicum rottboellioides H. B. K. Stendel earlier (Flora $33: 228.1850$ ) mentions the name in a paper on the progress of his work on the "Synopsis plantarum." The generic description as given by Steudel is faulty and mislearling. He evidently became confused as to the morphology of the parts of the spikelet. But reading his description with a dissected spikelet of $P$. rottboellioides under the microscope one can see that this is what Stendel is trying to describe. It seems likely from his description of the "flosculus hermaphroditus" that he mistook the sterile lemma with the fertile floret enfolded for the hermaphrodite floret (that is mistaking the fertile lemma for the "seeond valve" of the floret). Steudel's statement that $M$. cayennense approaches Panicum mesocomum Nees is further misleading. For this reason the name Yesosetum has been referred to various sections of Panicum but never, so far as we can find, to the group containing Panicum rottbollioides, until so used by Hitcheock (Contr. Nat. Herb. 12 : 211. 1909). Bentham (Linn. Soc. Journ. Bot. 19 : 42. 1881) says that Panicum leucophaeum H. B. K. (which is Panicum insulare (L.) Meyer, Valota insularis (L.) Ghase)

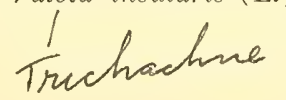


"appears to have been the type of the proposed genera Acicarpa, Raddi, Eriachne, Philippi, and Holosetum and Mesosetum Steud." (It is in fact the type of only the first-named of these.) In the Genera Plantarum (Benth. \& Hook. Gen. Pl. 3 : 1101. 1883) he says that Mesosptum is perhaps (forte) referable to the section Trichachne of Panicum. At the same time Bentham (Linn. Sor. Jonrn. Bot. 19: 4:. 1881) extablishes as a section of Panicum his Diplaria comprising "P. rottborllioides, H. B. K., $P$. exaratum and $P$. ferngineum Trin., P. pappophorum, Nees, and a few others." In the Genera Plantarmm (l. c.) this section is describer ant the same species mentioned as belonging to it. Dalla Torre and Ifarms (Gen. Siphonog. 14. 1900) also include Mesosetum, together with Allnteropsis Presl, Coridochlon Nees, Eriachne Phil., as well as Acicarpa liaddi and Trichachne Nees which properly belong there, under Panicum, suction Trichachne. Stendel himself failed to see the identity of his Ifesosetum cayennense with $P$. rottbollioides or its affinity to the other species of this group which he includes nuder the section IIarpostachys (Syn. Pl. Glum. 1 : 5.5. 1854). It was only Prof. Hitcheock's examination of the type specimens of Mfososetum cayennense and $P$. rotthellioides, hoth now in the Herbarinm of the Muséun d' Histoire at I'aris, that revealed the specific identity of the two. It is unfortunate that stemlel's generic name, with its inadequate description, must stand for this well-markerl genus. But if the names of all incorrectly tescriber genera were rejectert the nomenclature of the Graminae wonld undergo many changes, for this family seems particularly to have suffered from the misunderstanding by anthurs, of the morphology of the parts of its inflorescence. Anthaenantia, Ichnonthus, Alloteropsis and Pentarrhaphis are examples of valic genera incorrectly described by the anthors who bestowed the names we nse for them.

lescription.-Inflorescence a single, terminal, erect, spike-like raceme, the spikelets subsesile, solitary, alternate in two rows on one sile of a three-angled, rarely winged, tortuons or zigzag rachis, the spikelet with the back of the fruit turned from the median line of the rachis (the first glume towards it), ventricose on the side toward the rachis, and fitting into its concavities, the back of the spikelet flat or nearly so; glumes : 3 - to 5-nerved (when 5-nerver the lateral pairs of nerves approximate) the lateral nerves often uniting with the milnerve below the acute or acmminate summit, one or both nsually clothed on the margin with stiff hairs; sterile lemma like the glumes in texture and the distribution of the pulsescence, usually appearing :-keeled from the strong lateral nerves and firm lateral intemerves and thin or hyaline midille internerves and weak midnerve; sterile palea wanting except in the section Bifaria; fruit pointerl, ventricose on the face (palea sirde) usually straight on the back, the lenma anrl palea less indurated than in Panicum, the flat inargins of the lemma not hyaline. Slender perennials with narrow leaves, the uppermost reduced to a blarleless or nearly bladeless sheath.

This genus, like Brachiaria, differs from Panicum in the strictly race. mose inflorescence and reversed position of the spikelets, and further in the form of the spikelets, swollen or ventricose on the face (or first glume 
side) instead of on the back as in Panicum, Paspatum and, in more or less pronounced form, in all other genera of the Paniceae. The fruit differs from that of Panicum in having less indurated lemma and palea, the margins of the lemma flat. Doell (in Mart. Fl. Bras. 2: ${ }^{2} 179.1877$ ) states that in this group of plants the caryopsis has a linear hilum, but the specimens in the National Herbarium are not matnre enongh to permit of verification of this statement. The genus is confined to the tropics of the western hemisphere, Brazil being the center of distribution, two species occurring in the West Indies.

Besides Mesosetum proper the genus contains a well-marked section.

First glume awnless; lower floret neuter . . Mesosetum proper.

First glume awned; lower floret staminate. . Section Bifaria.

\section{Mesosetum proper.}

This contains the following species:

Mesosetum rottboellioides (H. B. K.) Hitche. Contr. Nat. Herb. 12 :

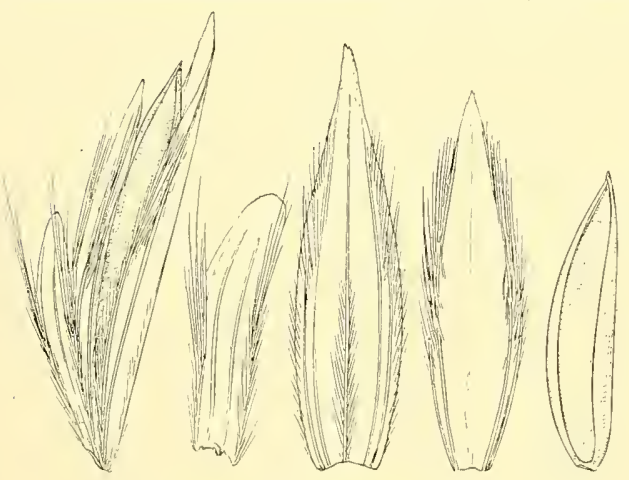

Fig. 3.

Mesosetum rottboellioides.

(Spikelet, first glume, second glume, sterile lemma and fruit $\times 10$ diam.)

211. 1909. Based on Panicum rottboellioides H. B. K.

Panicum rottboellioides H. B. K. Nor. Gen. \& Sp. 1 : 96. pl. 32. 1816. "Crescit in humidis ripe Orinocensis inter Maypures et montem sipapo.'"

Mesosetum cayennense steur. Syn. Pl. Glum. 1 : 118. 1854. (See above.)

\section{Mesosetum Wrightii}

Hitche. Contr.

Nat. Herb. $12: 211.1909$. " Wright 3859 no. 559961 in the U.S. National Herbarium."

This species is known only from Cuba.

\section{Mesosetum exaratum (Trin.).}

Panicum exaratum Trin. Gram. Pan. 160. 1826. "Brasil. (LaxgsDorfF.)" The type specimen, in the Trinius Herbarimm, is labeled "Panicum exaratum m. In pratis paludosis S. da Lapa. Brasil. leg. cl. de Langsdorff."

Panicum pappophorum Nees, Agrost. Bras. 104. 1829. "Habitat * * * provinciae Piauhiensis." The type specimen, in the Munich Herbarium, bearing the name and locality as published, was collected by Iartius. 
Mesosetum Ioliiforme (Hochst.) Chase, Bot. Gaz. 51 : 302. 1911. Based on Panicum loliiforme Hochst.

Panicum loliiforme Hochst. in Stend. Syn. Pl. G]um. 1:56. 1854. "Herbr. Dr. Hostmann nr. 1071." The type specimen is in the herbarium at Leipzig.

This is the not uneommon Cuban speeies which has been nwally referrerl to $P$. rottboellivides in herbaria. It liffers from $I$. rottboellioides anfl $M$. Wrightii in having glumes each bilaterally m-ynmetrieally developed, the second shorter than the first instead of being the longest scale of the spikelet as in $\boldsymbol{H}$. rottboellioides ; $M$. lolifforme also differs in being sparingly stoloniferous.

Nees' $P$. papmohorum var. $\beta$, his speeimen of which, also colleeted by Martins in Brazil, is now in the Munieh Herbarium, is either M. loliiforme or a very elosely allied speeies.

\section{Mesosetum chlorostachyum (Doell).}

Panicum chlorostachyum Doell in Mart. Fl. Bras. $2^{2}: 173$. pl. 28. A. 1877. "Ilahitat in regionibus fluminis Rio Negro (Spruce n. 88.5, 1310)." spruee's no. 885 is in the Munich Herbarium.

\section{Mesosetum ferrugineum (Trin.)}

Panicum fermgineum Trin. Gram. Pan. 1826. "Brasil (LwasDonFr)." The type speeimen, in the Trinins Herbarium, is labeled "Panicun ferrugineum m. In eampis glareosis pr. s. Luzia, Brazil. 1. mense Uet. 18:4. el. LA.NGSDORFF."

Panicum eriochrysenides Nees, in Trin. Gram. Pan. 160. 1826. This name is given as a synonym of $P$. fermginenm. Nees (Agrost. Bras. 103. 18*9) publishes this as a new species citing a specimen eollected in Brazil hy Sellow, "Vidi in IJerb. Reg. Berol." What is evidently a duplicate of this is in the Trinins Herbarium. Nees gives "Panicnm ferrnginemu $T r$. in litt." as a synonym of $P$. eriochryseoides.

Mesosetum sclerochloa (Trin.) Hitchc. Contr. Nat. Herb. 12: 212. 1:100?. Baserl un Panicum sclerochloa Trin.

Panicum sclerochloa Trin. Gram. Icon. 3 : pl. 283. 1836. The illustration is Irawn "arl specimen Brasilianmm." The type, in the Trinins Herbarium, is labeled "Panicum sclerochloa m. pr. Cuyaba febr. 18:2.",

This peculiar species shows an approach to the speeies of the seetion Bifaria in the thickened midnerve of the first glume, keeled toward the apex and protruling as a short, laterally compressed point from between the lobes of the slightly cleft smmmit of the glume. The midnerve of the seeonil glume and that of the sterile lemma are similarly keeled.

Besiles the species listed above, Ponicum lolinm Nees, the type specimen of which has not been examined, and a few other insuttieiently known Sonth American speeies belong in this genus. 
Section Bifaria (Hack.).

Hackel (Oesterr. Bot. Zeit-chr. $47: 75.1897$ ) establishes Panicum, section Bifaria with three new Brazilian species, P. bifarium, P. caudiculatum and $P$. elytrochaetum. Professor Hackel kindly contributed to the National Herbarium a spike from the type specimen of $P$. bifarium; the other two species have not been examined. The spikelets of $P$. bifarium have the structure and reverserl position characteristic of Lesosetum but differ strikingly in the character of the first glumes. In these the midnerve, which (as in most species of Mesosetum proper) is joined by the lateral nerves, is keded towarl the summit of the notched glume and extends into a laterally compressed, sinnons, stout awn, varying from a short point to as long again as the spikelet. The species differs fnrther from those of Mesosetum proper in liaving a staminate flower in the lower floret. Prof. Hackel points ont the relationship of his section Bifaria to Bentham's section Diplaria ( $P$. rottboellioides, $P$. loliiforme, ete.), and becanse of this relationship establishes for his three species a section of Panicum instead of a new genns. But unless the boundaries of the genus Panirum are extender to the limits to which Trinius (Gran. Pan. 1826) stretched them, inchuling Paspalum, Oplismenus, Setaria and other genera recognized as distinct by even the most conservative students of Gramineae, the species here referrerl to Mesosetum with their constant combination of characters and their sharp delimitation from Panicum (there being no intergrading species as between Panicum and Paspalum and between Panicum and Chaetochloa) can not well find place therein.

The only species of the section Bifaria we have seen is here transferred:

\section{Mesosetum bifarium (Hack.).}

Panicum bifarium Hack. Oesterr. Bot. Zeitschr. 47:76. 1897. "Serra da Baliza ad Cachoeiras cla Vargem Crante, 5-I. 1895, Glaziou nr. 22455."

Bifaria bifaria Kuntze, Gell. PI. : : : 359. 1898. Based on Panicum bifarium Hack. Kuntze, apparently withont having seen the species, raises Hackel's section, on account of the lobed and awned first ghmes, to generic rank in order to be consistent, he having maintained Oplismenus and Chaetium as distinct genera, he says, because of this characteristic.

\section{Gexus LetCol'HRYs Rendle.}

Leucophrys Rendle, Cat. Afr. I'l. Wehwitsch $2:{ }^{1} 193.1899$. This genus is based on a single species, L. mesocoma (Nees) Rendle (op. cit. 194) basel on Panicum mesoromum Nees, an difrican species. In this genus the spikelets are placed with the Jack of the fruit turned from the axis, but, not being strictly racemose, this is not readily observed. The rachilla is produced into a short stipe below the first glume which is separated from the second by the slightly prolonged second joint of the rachilla. The nearly glabrous first glume about as long as the spikelet and the densely silky second glume and sterile lemma, as well as the narrow 
panicle and the reverse position of the spikelets, snggest an approach to the unique North American Panicum ciliatissimum Buckl. The stipitate spikelet of Leucophrys, however, with a joint between the glunes, and the different arrangement of the silky pubescence on the second glume and sterile lemma (a lense ring of long hairs across the middle of the spikelet, an arrangement also found in Panicum nigropedatum, P. serratum, $P$. argenteum, etc., and approached in several species of Eriorhloa) does not show a close aftinity with $P$. ciliatissimum. Species intermediate between them may be found, but withont such intermediate species our $P$. ciliatissimum finds a more natural place in Panicum. Stuly of more material may show that Panicum argenterm and its allies should be plaeed in Leucophrys.

Rendle (1. e.) places Leucophrys immediately hefore Tricholaena to which he eompares it. The silky spikelets resemble outwardly those of Tricholnena but the inclurated fruit and membranaceous, entire and awnless second glume and sterile lemma indicate but remote relationship to that genus. The two, however, probably belong closer together than is indieated by their relative position in the sequence here given, but it must be borne in nind that any lineal arrangement of that which is really irregularly radiate must fail to show all but the closest relationship.

\section{FENTS ERIOCHLOA H. B. K.}

Eriochloa H. B. K. Nov. Gen. \& Sp. 1 :94. pl. 30 and :31. 1816. Two speeies are ineluded, E. distachya H. B. K. (1. c. pl. 30) "Creseit in ripa Orinoci Huminis inter Santa Barbara et Esmeraldam," and $E$.

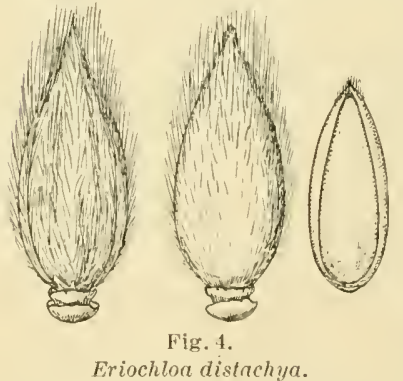

(Two views of spikelet and fruit $x$ 10 diam.) polystachya H. B.K. (1. c. pl.31.). Since both are illustrated and are equally eovered by the generic description the first species is here taken as the type of the genus. A duplicate type of this, "Ex herb. IJumboldt," was examined in the Berlin Herlarinm.

Helopus Trin. Fund. Agrost. 103. pl. 4. 18:0. A single species, $H$. pilosus Trin. (op. cit. 101) is inelured. Since the genus only and not the species is describerl and since no specimen is citerl we should consider the species based on Milium ramosum Retz., which is cited as a synonym, save for the fact that plate $f$ shows an aristate lemma while Retzins (Obs. Bot. 6:12. 1791) states that the "valyula exterior" is mucronate only, and that Trinins later (Gram. Pan. 11^. 1826) gives Helopus pilosus Trin. as a synonym of Paspalum punctatum Flügge (Milium punctatum L.), while Milium ramosum Retz. he gives as a synonym of Paspalum anmulatum Flügge. In the Trinius Herbarium is a speeimen collected by Mikan in Brazil, which is marked in Trinius' hand "Helopus pilosus m. Paspalum punctatum Flügge." Whether or 
not this specimen be taken as the type of $H$. pilosus we know that the species Eriochloa punctata (L.) Hamilt. (Prod. Pl. Ind. Oce. 5. 1825), based on Milium punctatum L., should be taken as the type of the genus Helopus Trin.

Trinius places Eriochloa H. B. K. immediately after Helopus in his systematic arrangement and (page 75) differentiates the two as follows:

Racemi ad rachin communem. Cor. apice mucronato-aristata . Helopus.

Racemi subpanieulati. Involuerum stella to-setosum! . . . . Eriochloa.

Probably Trinius had not at that time seen Kunth's species and was impressed by Kinuth's description of an involuere of numerous hairs at the apex of the pedicel and by the ring of spreading hairs shown in plate 30 . Later (Mém. Acad. St. Pétersb. VI. Sci. Nat. $3:{ }^{2} 130$ and 138. 1834) the species of both Eriochloa and Helopus are placed in Paspalum in the subdivision Helopus.

Oedipachne Link, Hort. Berol. $1: 551.1827$. This inclules a single species, O. punctata Link (1. c.), based on Milium punctatum L. In his additions and emendations (p. 273) Link directs that Oedipachne be expunged and Helopus Trin. be inserted in its place, and in the second volume (Hort. Berol. 2:199. 1833) Helopus is given as a genus with Oedipachne as a synonym. Eriochloa H. B. K. seems to have been overlooked by Link.

Alycia Willd.; Stend. Nom. Bot. ed. 2. 1:66. 1840. This herbarium name is listed without description, and two undeseribed species, $A$. coarctata Willd. and A. distachya Willd, are listed under it. Both names are here referred to Helopus brachystachys but on page $747 \mathrm{~A}$. coarctata Willd. is referred to Paspalum polystachyum Trin. and A. distachya to $P$. brachystachyum Trin. Helopus brachystachys Trin. (upon which Puspalum brachystachyum is based) is Eriochloa distachya H. B. K. or a very closed allied species, while Paspalum polystachyum Trin. is based on Eriochloa polystachya H. B. K., so that whichever species be taken as the type of Alycia this name becomes synonymous with Eriochloa H. B. K. Willdenow's herbarium name is spelled "Aglycia" by Steudel (op. cit. 37 ) with the same two species listed under it.

Nees (Agrost. Bras. 16. 18:9) recognizes Helopus Trin. as a genus, and does not mention Eriochloa. Probably since neither of Kunth's species was from Brazil Nees neglected to study the genus.

Doell (Mart. Fl. Bras. 2: ${ }^{2}$ 123. 1877) recognizes Helopus Trin. as a genus, and includes Eriochloa H. B. K. under it. Bentham (Benth. \& Hook. Gen. Pl. 3 : 1099. 1883) recognizes Eriochloa H. B. K.

Nash (Bull. Torrey Club $30: 37 t$. 1903) takes up the name Monachne Beanv. for this genus, but we do not find this name tenable. It is based on $M$. unilateralis Beanv., an undeseribed species unrecognizable from the figure, which represents a branching paniculate inflorescence, thongh the spikelets were evidently drawn from some species of Eriochloa, and Saccharum reptans Lam., which is a species of Panicum allied to P. urvilleanum Kunth. 
Description.-Inflorescence of one to many, usually dense, racemes along a common axis; spikelets solitary, sometimes in pairs, short pediceled or subsessile in two rows on one sile of a narrow, nsually hairy rachis, the peclicels often clotherl with long stiff hairs [the "involucre" of $k m t_{1}$, the back of the fertile lemma turned from the rachis; spikelets dursally compresed, more or less pubescent, stipitate by the lengthening of the internote of the rachilla below the second glume into a more or less ring-like, usually dark-colored calluk, the first glume reduced to a minute sheath about this internode and arhate to it; secoml glume and sterile lemma equal or nearly so, acute or acuminate, the lomma usually enching a hyaline palea and sometimes a staminate flower; fruit induraterl, less so than in Panicum, ninutely papillose-rugose, the lemma mucronate-pointed or aristate, sometimes pubescent at the apex, the margins slightly inrolled. Perennial herbs with linear lesares and terminal panicles of few to many racemes, confined to the wamer temperate and tropical regions of both hemispheres.

This genus approaches Leucophrys and Brachiaria throngh such species as Panicum nigropedalum Munro, $P$. argenteum R. Br., and $P$. serratum R. Br. in which the first glume is well developed abuve the more or less stipitate base.

13. GENTs BR.ACIIIARIA (Trin.) Tirisel).

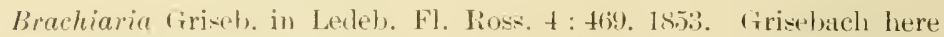
raises "P’unicum sect. Brachiaria Trin." ( Mém. Acad. St. Pétersb. VI. sei. Nat. $3:{ }^{2} 194$. 18:34) to a genus, including unker it a single species

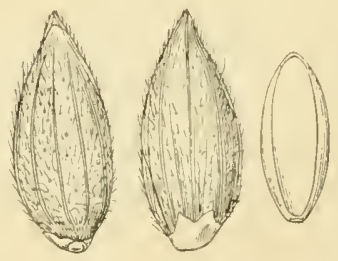

Fig. 5.

Brachiaria erucifurmis.

(Two views of spikelet and fruit x 10 (iam.) B. eruciformis (smith) (irised). baserl on Panicum eruciforme smith (Sibth. Fl. Graec. 1 : 44. pl. 5y. 1806). "In arvis circal Junonis templum in insula stmo." The plate is a goml representation of the species and fully identifies it. The enlargerl portion of the raceme (i. A) shows that the spikelets are placed with the first glume towarl the axis. This species we here take as the type of the gemus. Ruemer of sehultes (syst. leg. 2: tot. 1817) misivell the name "cruciforme," and in this form also it appears in the Index Kewensis umler Brachiaria.

Grisebach cites not the first work in which Trinins proposes the subgenus Brachiaria, but a later work, in which Trinius includes a sonewhat different gronp of species from those incluted in his first establishment of the section in "De Graminibus paniceis" (pages 51 and 125. 18.2(i). Here (1.51) the section is liagnosed as follows: Ratcemes simple, regularly or irregularly alternate; spikelets oblong (rarely lanceolate), either in regular series and imbricated or laxly disposed; lower glume manifest, awnless. Under it are included "Thrasya Kith.? * * * 
Urochloa Pal. [de Beauv.] * * * Atreptostachys Desv., Echinochloa Pal." In the body of the work (p. 125) the first species inchded under section Brachiaria is Panicum decumbens Roem. \& Schnlt. (Paspalum decumbens Poir.), the species which later (Mém. Acar. St. Pétersb. VI. Sci. Nat. $3:{ }^{2} 227.1834$ ) is the first included under section Harpostachys of Trinius. This is followed by Panicum thrasyoides and $P$. cultratum (species of Thrasya), several species of Panicum (in the strieter sense) and of Echinochloa; $P$. holosericeum and $P$. argenteum, in which the spikelets are in the reversed position and which are the first species under section Brachiaria as later used by Trinins, are here only the seventeenth and eighteenth species under that section. In the "Panicearum Genera" (Mém. Acacl. St. Pétersb. VI. Sci. Nat. $3:{ }^{2} 194.1834$ ), which Grisebach cites, Trinius makes Brachiaria the eighth section of Panicum, Harpostachys, to which are relegated the species with a single raceme earlier included in Brachiaria, being the serenth. The characters now assigned to Brachiaria are: Simple, altemate racemes, the partial axes angled (usually 3-angled); sessile or short-pediceled, glabrous, pilose, or lanate, awnless spikelets, imbricated in ?, 3, or 4 series. No species is here mentioned, but under "VIII Brachiaria" (pages 233-247) this purely artificial division contains thirty diverse species referable to Brachiaria (as here limited), Echinolaena, and the greater number to Panicum. Since there is nothing in either work to indicate which species should be considered the type, it seems best to follow Grisebach's choice when he established Brachiaria as a genus. His choice, to be sure, was guided by the lact that Panicum eruciforme was the only one of the group which occurred in the Russian Empire, but even so, it would be unwise to reject his type and arbitrarily to choose another. Panicum eruciforme is included, under the name "Panicum Isachne Roth!"' by Trinins in the first subdivision of his section Brachiaria as himited in the "Panicearmm Genera." Later in the "Graminum Supplementa" (op. cit. $4:{ }^{1} 103$. 1836) he states that $P$. Isachne shonld be called Panicum eruciforme. Trinius' first three species, $P$. holosericeum R. Br., P. argenteum R. Br. and $P$. serratum Spreng., are of that peculiar group of Old World species with reversed spikelets elothed with silvery hairs more or less aggregated across the middle of the second glume and sterile lemma, and having a well-developed first glume, which, together with Lencophrys, appear to be a connecting link between Eriochloa and Brachiaria. In the present state of our knowledge it is difficult to say whether these species fall the more naturally into Brachiaria or into Leucophrys.

Grisebach does not mention the reversed position of the spikelets in Brarhiaria, and later (Goett. Abh. 7 : 263. 1857) transiers to this genus Panicum prostratum Lam. ( $P$. reptans L.), a species in which the spikelets are not in the reversed position. In the "Flora of the West Indies" (page 545. 1864) Grisebach uses "Brachiaria Tr." as a section of Panicum, including under it Panicum paspaloides Pers. [P. geminatum Forsk. is intended] and three species of Echinochloa. 
Stendel (Syn. Pl. Ghmm, $1: 56,1854$ ) follows Trinius' own later limitation of the snlogenns Brachiuria.*

Bentham (Benth. \& Hook. (ien. Pl. $3: 110$.2. 1853) uses the name Brachiuria for a section of Panicum and in about the sense equivalent to the gronp Geminata (Hitchc. \& Chase, Contr. Nat. Herb. 15 : 30. 1910). Hackel (Engler \& Prantl. Pflanzenf. 2 : ${ }^{2} 35.1857$ ) also nses it as a section of Panienm and apparently in the same way, his diagnosis being: Inflore-cence as in Paspalum, spikelets awnless.

Nash (Britton, Man. 77. 1901) recognizes Brachiaria as a genus (giving Lerlebonr as the author), differentiating it by the racemose inflorescence and awnless spikelets of 3 glumes. Two species, Panicum digitarioides ( $P$. hemitomon schult.) and $P$. obtusum H. B. K., in both of which the spikelets are in the position normal for Panicum and Paspalum, not the reversed position of Brachiaria eruciformis, are transferred to it. Later (in Small, Fl. Sontheast. U. S. 50 and So. 1903) Nash adds to his diagnosis of the genn Brachiariu "Howering scale with its opening toward the rachis," thus limiting the genus to Grisebach's type species and its allies. Punicum digitarioides and $P$. obtusum he here restores to Panicum. Hitcheock (Contr. Nat. Herb. 12:141. 1908) acepts Brachiaria in this emendert sense, separating it from Panicum chiefly on accomt of its "havingspikelets so placed that the fertile floret stands with its palea toward the axis."

See also Bub. p. 293

Vilium Bubani, Fl. Pyren. 4 : 259. 1901, not L. 1753. This inchudes a single species, M. alternans Bubani, baved on Panicum eruciforme smith. No generic description is given but something of the author's concept of the genns is shown by his statement that it is not possible to separate Punicum beckmanniaeforme Mikan (P.geminatum Forsk.) from Milium ulternans, indicating that Milium is nsed in the historie sense. fow what we now cael manicume of several to masuall hise racemes along a conmon axis; spikelets solitary, rarely in pairs, subseswile in two rows on one side of a :3-angled, sometimes narrowly winged rachis, the back of the fertile lemma tnmed from the axis; spikelets dorsally compressed, sometimes turgir; first glnme nsually less than half the length of the spikelet; second glume and sterile lemma equal or nearly so, 5- to 7 nerver, the lemma enclosing a hyaline palea and sometimes a staminate Hower; truit indurated (in the type species smooth and shining) usually lemma apiculate papillose-rngose, the ${ }^{\prime n}$ lingins of-the-lenma inrolled, the apex rarely or awn tipad, the mitlerenate pointed. Anmmas or perennial, branching herbs with linear leaves, the culms often decumbent and rooting at the lower nodes, confined to the warmer temperate and tropical regions of both hemispheres.

$5=1-$ Brachiaria is here distinguished from allied genera by the strictly racemose inflorescence and reversed position of the spikelets (in which the first glume is present) taken in combination.

*Schlechtendal's stricture (Linnaea $26: 537.1853$ ) of Steudel for including under Panicum section Brachiaria Trin. a different aggregation of species from that included under it by Trinius himself, must have been made in ignorance of Trinius' later paper, for Steuclel, not only includes the sime species as did Trinius, but gives them in the same order, only interspersing a few of what he considers allied species. 
Among North American species of Panicum two approach Brachiaria or Leucophrys, Panicum texanum Buckl. and P. ciliatissimum Buckl., in which the inflorescence is not strictly racemose, but in the first of which the spikelets toward the ends of the branches are often in the reverse position of those of Brachiaria, while in the second all the spikelets are in the reverve position. The rugose apiculate fruit of both also recall the fruit of Eriochlor and of one species of Brachiaria, B. meziana Hitche., but the spikelets are not in one-sider racemes.

\section{GexUs AXONOPUS Beaur.}

Axonopus Beanv. Ess. Agrost. 12 and 154. 1812. A brief diagnosis is given and the following species cited as belonging to the genus: "Milium compressum [Axonopus compressus (Swartz) Beaur.], digitatum [Syn-

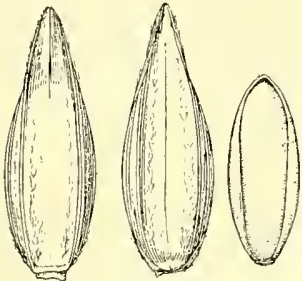

Fig. 6.

Axonopus compressus. ( Two views of spikielet and fruit $\mathrm{x} 10$ diam.) therisma digitata (Swartz) Hitchc.], cimicinum [Panicum cimicinum ( L.) Retz., Coridochloa cimicino (L.) Nees], paniceum [a species of symtherisma]." There is little in the diagnosis or observations to favor one species more than another as the type, but such as there is favors H. compressum, since honopus is differentiated from Ceresia and Paspalum on the digitate inflorescence and solitary spikelets. All but the first species named have spikelets in pairs. This species, therefore, we take as the type of Axonopus. Beauvois himself expresses doubts as to the validity of his genus. He says that if Milium can be separated from Paspalum hecanse the axis of the latter is a spike composed of spikelets alternate or geminate, the same character (motif) wonld serve to distinguish Aronopus in which the axis is digitate; at least if one does not remite the three genera, forming of each a division of the same genus; this, he says, would be perhaps the most natural. But, he adds, "C'est anx Botanists à prononcer: il me suffit de leur présenter mes doutes." Next follows a brief, informal description of a plant received from " M. de Lessert," which, it appears to Beanvois, ought to helong to this genus, with the name of Axomopus aureus. In the index (page 154) all five species mentioned are listed under Axonopus, but all except "aureus" are followed by a question mark. But we find that under Milum in the index these same species are again queried. It would seem that the query refers to the anthor's doubts as to the advisability of keeping Paspalum and Axmopus distinet from Milium. The omission of the question mark after "aureus" may be a typographical error. However, we hold dronopus compressus and A. aureus to be congeneric, but to belong to two rather well-marked sections.

Cabrera Lag. Gen. \& Sp. Nov. 5. 1816. A single species is given under this genus, C. chrysoblepharis Lag. "H. in America meridionali, ad Panamaidem et Aricam portum, ubi legit. cel. D. Lud. Neé (V. S.)." The type specimen has not been examined but the clear and detailed descrip- 
tion identifies the species with that descriher as Paspalum immersum Nees. In this species and its close allies the 3 -angled rachis is abont $1.5 \mathrm{~mm}$. wide, the margins and milrib hearing stiff golden hairs arising from papilla, a few hairs also at the side below the spikelet, but not hearing a farcicle of hairs beneath the spikelet as in Aromopns aureus. The spikelots in Cabrera chrywolepharis fit into shallow depressions in the rachis, the effect of an excavation being heightened by the surrounding piliferous papille. In . 1. anews, to which Lagasca's species has been referred by many authors, and its close allies, the narrow rachis is ciliate on the margin (not down the center also as in Cabrow chrysoldepharis), and below each spikelet, "in the form of an involucre," as Beauvois says, is a fascicle of bright golden hairs exceeling the spikelets which are not set in excavations of the rachis. Nees (Igrost. Bras. T. 1 18:9) includes Axomrpus anrens Beanv. (under the name l'aspolus immersus* to which he

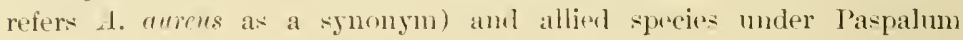
"sectio VI. Axomopoles." Apparently he failed to note that in these sfrecies as well as in Iresifulum romipressum and its allies, of which he makes "Suctio I. Inigitariac," the solitary spikelets are in the reversed pustion. Nees refors " "ien. Cabrera Lag." to this section Amompodes. Lagasea's species, 6 . chrysoblephoris, le refers as a synonym to his own

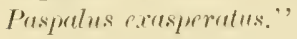

Anestrophus shlecht. Bot. Zeituchr. S : 6\$1. 1850. The author discusses Prspulum section lligiturige "(spiculis insersis)" of Nees and proposes a generie nane for it. He lists moler this gemus the names of eight species, three of them numblisherl herbarimn names. The first of the species (all of which are indurler in the section I)igitariar by Yees) is Paspalum plutyculmum Thon. This species, which we take as the type, was described by Vees (. Igrost. Bras. 24. 1.29!) from a specimen bearing this name in the Willdenow Horbarium. Wa have not seen the specinen, which was mollecterl in "insula s. Manritii," but Vees' deseription shows it to be closely related to frommus commessus. Schlerintemlal does not himself

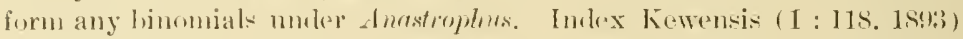
transfers all names, including nomina mula, mentioned by schlechtendal in his parr. schlechtendal does not here make any mention of Irmmpus, but in a later paper (linnaea $26: 592.185 \%$ ), discussing Limmpus Beaur., he remarks that he has alrearly established Anastrophus and has theroby hegm the destruction of the gems stromopus of Beaur., and that nuw Calnem Lag. must be separated from it. [since Nees did not mention the reversed position of the spikelets in this gromp, as he disl in the group schlechtendal named hustromus, neither does Schlechtendal note this warater, although when discussing inastrophe he lail great stress upon it.]

llackel (Engler \& Prantl, Pflanzenf. 2 : ${ }^{2}$ 35. 1ss7) makes Anastrophus his third section of Paspalum, noting that the lower glme and lemma are turnerl from the axis. Tash (small, Fl. sontheast. L. S. 79. 1903) recognizes Anustrophus as a genus.

\footnotetext{
* Nees uses throughout the masculine form of this name.
} 
Lappagopsis Steud. Syn. Pl. Glum. 1 :112. 1854. This genus is proposed with a single species $L$, bijuga Stend. "Uvville legit in Ins. St. Catharin. et Claussen in Brasil.", The Clanssen specimen referred to is in the Kew Herbarium. It is found to be closely related to Paspalum dissitiflorum Trin., which species Nees (Agrost. Bras. 32. 1829) includes in his section "Digitariae (speculis inversis)." Hackel (Engler \& Prantl. Pflanzenf. $2:{ }^{2} 35.1887$, where the name is misspelled "Lappagrostis") includes it in section Anastrophus.

Owing to its insufficient diagnosis and the diverse species assigned to Anoxopus by Beauvois this name has been applied to different gronps of species by different authors. Roemer \& Schultes (Syst. Veg. 2 : 318. 1817) recognize it as a genus inchuing under it the same species as did Beauvois except A. paniceus which, they say, is Paspalum filiforme [it is a species allied to Syntherisma filiformis]. Nees, as we have seen, used it as a section of Paspalum for the species allied to A. aureus. Hooker (Fl. Brit. Ind. $7: 64.1896$ ) says of Axonopus "A natural genus, remarkable for the small cleft palea of gl. III [the sterile palea]. It was established by Beauvois on Panicum cimicinum Retz, to which other grasses having no affinity with it were adder." Hooker does not state why he takes $P$. cimicinum as the basis of Amoxopus. It fails to agree with one of the two characters of Beauvois' diagnosis (in that its spikelets are not solitary), and it is only third in the list. Hooker liere includes one other species in this genus, A. semialatus (based on Panicum semialatum R. Br.) Stapf (Dyer, Fl. Cap. $7: 418$. 1895) accepts the genus as emender by Hooker. Hitcheock (Rhodora \& : 205. 1906; Contr. Nat. Herb. 12 : 141. 1908; Gray, Man. ed. 7. 100. 1908; Contr. Nat. Herb. 12 : 207. 1909.) recognizes $A$ conopus for the congeners of $A$. compressus.

Description.--Inflorescence of 2 to many slender racemes usually aggregated at the summit of the culm; spikelets solitary, sessile and altemate in two rows on one side of a 3 -angled rachis, the back of the fertile lemma turned from the axis; spikelets depressed-biconvex, not turgid ; first glume wanting; second glume and sterile lemma equal; sterile palea obsolete; fruit indurated, oblong-elliptic, usually obtuse, the margins of the lemma slightly inrolled. Stoloniferous or tufted perennials, with flat, conduplicate or involute, linear leaves; species numerous in South America, a few species extending into subtropical and warm temperate regions of North America and one or two to the warmer parts of the Old World.

The characters to which we here attach chief value as generic are the reversed and solitary spikelets (in which the first glome is wanting) and the racemes aggregated at the summit of the culm.

The genus Axonopus as here understood, subdivides into three rather well-marked sections as follows:

Rachis and spikelets glabrous or the latter softly pubescent, neither bearing conspicuous, stiff, spreading hairs . . . . . . . . . . Axonopus proper.

Rachis and sometimes spikelets bearing conspicuous, stiff, spreading hairs. 
Spikelets glabrous or minutely pulescent, the hairs of the rachir golden . . . . . . . . Section Carrera. Spikelets papillose-pilose, the hairs of these and of the rachis pale . . . . . . . . Section Lappagorsis.

In North America Axonomes proper is represented by the following species:

Axonopus compressus (Sw.) Beaur.

Milium compressum sw. Prod. Veg. Ind. Oce. "4. 1788. "Jamaica; Inlia oecidentalis." No specimen of this conla be found in the Swartz Iferbarium, but the later detailed description of swartz (Fl. Ind. Oce. 1: 183. 1797) leaves no rom for doubt.

Paspalum platicaulon I'oir. Encyc. Suppl. 5 : 34. 1804. "Cette espèce a été recneillie à Porto-liceo, par le citoyen Ludru. (V.s. in herb. Lam. )." The tyle has not been examined but the description identifies the surecies.

Aronopus compressus Beauv. Ess. Igrost. 12. 1812. Based on Milium compressum sw.

I'aspalum commessum Rasp. Ann. Ȧei. Nat. I. s : 301. 1825. Based on A xonouns commessus beauv.

Anastrophus platyearlis sichlecht.; Inu. Kew. 1: 118. 1893. Based on Paspalum platycaule.

('osely relater to this species is a narrower-leaved form with nearly obtuse spikelets and usually few racemes which may lesespalum tri-

= a.compressus see Lam. Encycl. slactiyon Lam. (Tahl. Fucyel. 1: 176. 1791. "Ex America merid. ComInumic. D. Richard"), This name has heen referred ly Trinius and others to P. platycanle, hut Lamarek's description "spicis ternis" points to the other form. The type has not been examiner.

Axonopus furcatus (Flügge) Hitche.

Paspalum furcatum Flügge, firam. Munog. 114. 1810. "Carolina. Bosc. IJalne." The type has not been examined, but the leseription identities the species.

Paspalum digitaria (\% Muell. Bot. Zeit. 1!1:324. 1861. "America septentrionalis, uhi forsan in Texas legit T. Drummond (coll. no. 2̌̈6)." The type specimm was examines in the Berlin llerbarium.

Axonopus furcatus Hitche. Rhunderat s: : $205.190(i$.

Michanx's name Digitaria paspalodes and reveral nanes based upon it, Vilium paspalodes Ell., Paspalum elliottii Wats., Paspalum paspalodes Ferilon., and Anastrophus paspaloides Nash, have heen misapplied to this spereses. Michanx's type specimen is Paspalum distichum 1..*

Axonopus Rosei (Scribm. \& Merr.).

Paspalum Rosei Scribn. \& Merr. U. S. Dept. Igr. Div. Agrost. Bull. 24:9. f. 2. 1900. "Foothills of the Sierra Madre Mountains, between

* See Hitchcock, Contr. Nat. Herb. 12:146. 1908. 
Pedro Paulo and San Blaseito, 1995 J. N. Rose, August 4, 1897.' The type specimen is in the National Herbarium.

\section{Axonopus capillaris (Lam.).}

Paspalum capillare Lam. Tabl. Encycl. 1 : 176. 1791. "Ex America merid. Comm. D. Richard."'

Puspalum minutum Trin. (Linnaea $10: 293.1836$ ), the type of which, collected by Poeppig in Peru, was examined in the Trinius Herbarium, appears to be based on depanperate specimens of A. capillaris.

The only North American specimens we have seen of this species are from Costa Rica, Puttier 508 and Jimenez 146.

\section{Axonopus laxiflorus (Trin.).}

Paspalum laxiflorum Trin. Mém. Acaul. St. Pétersb. VI. Sci. Nat. $3^{2}$ : 148. 1834. " V. spp. Bras." The type specimen, in the Trinius Herbarium, is labeled "Paspalum laxiflorum $\mathrm{m}$. In saxosis pratisque humidis S. da Lapa. Langsdorff."

This species is represented from North America in the National Herbarium by Pittier 214, Alta Verapaz, Guatemala, and Nelson 2738, collected between Guichocovi and Lagunas, Oaxaca, Mexico.

\section{Axonopus poiophyllus sp. nov.}

Plants perennial, tufted, flattened at the base; culms erect, slender, compressed, 60 to $90 \mathrm{~cm}$. high, simple, glabrous or minutely scrabrous below the appressed-pubescent nodes, the leaves mostly crowded at the base; lower slieaths much overlapping, keeled, villous, the upper pubescent along the margin, otherwise glabrous or minutely pubescent; ligule scarcely $0.5 \mathrm{~nm}$. long, erose-ciliate; blades erect, firm, linear, 8 to 35 $\mathrm{cm}$. long (the uppernost reduced to 0.5 to $2 \mathrm{~cm}$. long), 3 to $5 \mathrm{~mm}$. wide, the apex boat-shaped as in Poa, the lower conduplicate at base and slightly narrower than the summit of the sheatls, usually flat above, papillose-villons toward the base on both surfaces, scabrous on the upper surface; inflorescence of about 3 slender, erect racemes, 6 to $12 \mathrm{~cm}$. long, the rachis narrow, flexuous, glabrous or minutely scabrous; spikelets tinged with rose-purple, distant their own length, $3 \mathrm{~mm}$. long, $1 \mathrm{~mm}$. wide, oblong-elliptic, subacute, the second glume and sterile lemma slightly exceeding the fruit, minutely pubescent at the base and along the edges with appressed silky hairs, 4-nerved, the midnerve suppressed or nearly so, especially that of the glume, the lateral nerves near the margins and approximate; fruit pale, very obscurely papillose, the lemma with a minute tuft of erect hairs at the apex.

Type U. S. National Herbarim no. 860024 , collected in April, 1904, in the vicinity of Secanquím, Alta Verapaz, Guatemala, by O. F. Cook \& C. B. Doyle (no. 58).

This species is related to the group of cespitose South American species to which $A$. laxiflorus also belongs. 


\section{Axonopus deludens sp. nov.}

Plants perennial; culms genicnlate at base, leafy, strongly flattened, rather stout, 1 to 1.5 meters high, sparingly branching, glabrous, the nodes glabrous; sheaths glabrons or minutely pubescent at the smmmit; lignle abont $0.5 \mathrm{~mm}$. long, mentoranaceons, erose; hades rather thin and lax, linear, 15 to $45 \mathrm{~cm}$. long, s to $13 \mathrm{~mm}$. wille, flat, sparsely papillose-scalrons on the upper surface and on the margin, pubescent on the narrow auricles, glal,rous heneath, the miclnerve prominent; inflorescence of 6 to 15 very sender, erect or rather lax racemes, 10 to $25 \mathrm{~cm}$. long, the lower mostly naked at the hase, the rachis narrow, subflexnous, scabrons; spikelets purple tinged, distant about thejr own length or, toward the hase of the raceme, remote, $: 3$ to $: .2 \mathrm{~mm}$. long, 1 to $1.2 \mathrm{~mm}$. wide, obtuse, glahroms, the second glume and sterile lemmal covering the fruit but not exceding it, delicate in texture, 4 - or 5-nerved, the midnerve present or supuresiof even in arjacent spikelets, the lateral nerves strong; fruit papillore, smooth towart the summit and margins of the lemma, the apex glabrous or with a few obsenre hairs.

Type [. S. Tational Herbarimn 110. 460803, collecterl Oet. 20, 1903, Barranea near finalalajara, Jalisen, Mexico, log C . (i. Pringle (no. 8761).

This species is not chosely related to any other we have seen. The genienlate lower norles snggest a stoloniferons habit, but our one specimen does nut show stolons. The suppression of the milnerve in the glume or its presence is somewhat confusing, sinee it gives the impression of spikelets turned different ways, reverse and obverse, hut turning back the glume always hows the back of the fertile lemna turned from the axis.

There are sone eight or ten south Ameriean species, as yet insuthiciently known, that belong in Lxonomus proper. Perpulum suffultum Mikan (Trin. in Fureng. Nen. Entd. 22: 4t. 1821) is interesting as a species intermediate between Aronopus proper and section Cabrera. The axis is not eiliate but the very short pedicels bear at either side a few stifl hairs nearly as long as the spikelets.

Section' Cabrera ( Lag.).

\section{Axonopus chrysoblepharis (Lag.).}

Gabem chrysublepharis Lag. Gen. \& Sp. Nor.5. 1816. (See above under Cutrieru.)

I'rspulus immorsus Noes, Agrost. Bras. s".. 18*9. "Habitat in campis ultra 2000 peles altis provineiae Minarmm generalimn passim." The type specinen was examined in the Munich 1Ferlarinm. This is, as Nees inlicates, the species Kunth called Paspalum aurem, but since Kunth hased this name on Axonopus aureus beauv, his name is a synonym of that, misapplied to this species.

Panicum immersum Trin. Mém. Acarl. St. Pétersb. VI. Sci. Nat. $3^{2}$ : 197. 18:34. Based on Paspalum immersum Nees.

Panicum chrysoblephare Steud. Sym. 1'l. (ilum. 1:38. 185t. Based on Cabrera chrysoblepharis Lag. 
Paspalum chrysoblephare Doell in Mart. Fl. Bras. $2^{2}$ : 119. 1877. Based on Panicum chrysoblephare Steud.

The North American, specimens of this species in the National Herbarium are all from Costa Rica: Herb. Instit. pleysico-geogr. nat. costaricensis no. 4164, collected in "Savanes de Bornca," by Pittier \& Tonduz and no. 46:8, collected between Boruca and Terraba, by Pittier; 110. 11004 of the same series, collected by Pittier, is a mixture of A. chrysoblepharis and $A$. aureus.

\section{Axonopus aureus Beany.}

Axonopus aureus Beanv. Ess. Agrost. 12. 1812. Beaurois states that the plant was given him by De Lessert, but does not say whence it came. The specimen could not be found in the Delessert Herlarium. The author's observation "Locustes [spikelets] sont garnies, ensdessous, et en forme d'involucre, de poils conrt et dorés', points conchusively to one of the species with a clu-ter of golden hairs subtending the spikelets, these having a narrow rachis, not a broad one in which the spikelets are sunken as in A. chrysoblepharis. Following Trinius (Icon. 1: 1,1. 97. 1828) we take the common species with the smaller and glabrous spikelets to be the true A. aureus. The one with larger, pubescent spikelets, Paspalum canescens Nees (in Trin. Gram. Pan. 89. 18:6, not Roth. 1821, Panicum chrysodactylon Trin.), the type of which was examined in the Trinius Herbarium, has not been found in North America and for the present need not be transferred. The species of this gromp extending into North Ameriea is that called Paspalum aureum by Trinins.

Paspalum auream H. B. K. Yov. Cien. \& Sp. 1:93. 1516. Based on "Axonopus [misspelled Axinopus] aureus Beauv. agrost. p. 12." The species described and illustrated by Kunth (l. e. pl. 27 ) is A. chrysoblepharis.

Digitaria aurea spreng. Syst. 1 : 272. 1825. Based on "Paspalum aureum Humb."

Paspalum exasperatum Nees, Agrost. Bras. 81. 1829. "Ilabitat ad margines sylvarum prope Ferradas provinciae Bahiensis, in via Felisbertiana, quae descendit e Minis." The type specimen was examined in the Munich Herbarium.

Panicum aureum Trin. Mém. Acal. St. Péters]. YI. $3^{2}$ : 196. 1834. Based on "P[aspalum $]$ aureum Trin."

In North America this species also is known only from Costa Rica. ^In the National Herbarium are the following: Herb. instit. physico-geogr. nat. costaricensis no. 3305 , collected at Pacaca, by Pittier; no. 368., collected at Buenos Aires by Tonduz; nos. 11003 and 11004, collected at Cañas Gordas by Pittier, the latter having an intermixture of A. chrysoblepharis.

\section{A.S.H. 7987 \\ Panama}

Section Lappagopsis (Steud.).

\section{Axonopus dissitiflorus (Trin.).}

Paspalum dissitiflorum Trin. Gram. Pan. 92. 1826. "T. spp. Brasil. (LAxgsDonff.)" The typespecimen was examined in the Trinius Herbarium.

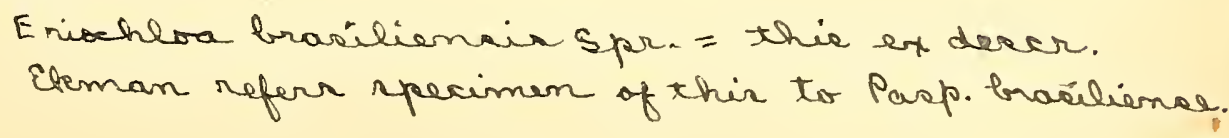


136

Chase-Notes on Genera of Panicle. IV.

Paspalus tenet Noes, Agrost. Bras. 92. 1829. This herbarium name is given as a synonym of $P$. dissitiflorum Trine.

This species is represented in the National Herbarium by Glaziou 15637, from Brazil.

Axonopus bijugus (stand.).

Iappagopsis bijnga Stent. Syn. PI. Glum. 1:112. 18.54. (See above under Lappagopsis.)

This more delicate species with smaller spikelets is represented in the National Herbarium by the following, all from Brazil: Burchell ss si, 7.03; Gardner 2!)

see piece from Two species described by Lees, Paspalum canaliculatum and P. fastThin. hb. = Hum - giatum, the types of which, both collected by Martins in Brazil, were toldiana crnear examined in the Munich Herbarium, belong in this section but being it ! insufficiently known are not here transferred.

15. sieves RELMARUCHLOA IItehe.

Reimarochloa Hitch. Contr. Nat. Herb. 12:198. 1909. "For R[eimaria] acute and its allied species the above name is proposed with Reimaria acnta Flügge as the type: Reimarochloa acute (Flïgge)" Ilitelie. Besides the type, two other species are

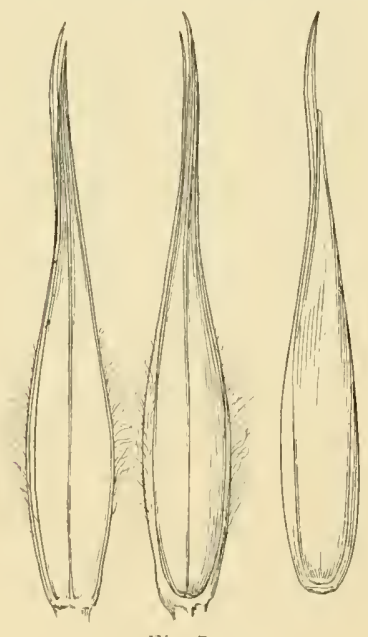

Fig. 7 .

Reimarochloa acute. (Two views of spikelet and fruit x 10 dian.) here included in this genus, leimarochlua brasiliemsis (Sprang.) Hitcher. and Reimsrochlou oligostachya (Munro) Hitches. For the discussion of Reimaria Flügge see this name nuder Paspalum.

Description. -Inflorescence of few to several slemiler racemes, approximate at the summit of the culm, spreading or reflexes at maturity; spikelets strongly dorsally compressed, lanceolate, acmenate, solitary, rather distant, subsessile and alternate in two rows along one side of a narrow, flattened rachis, the back of the fertile lemma turned toward it; both glumes wanting for the second glume sometimes present in the terminal spikelet); sterile lemma about equaling the fruit, sterile pale obsolete; fruit scarcely indurated, the lemma faintly nerved, acuminate, the margins enrolled at the base only, the pale free nearly half its length. Stoloniferous perennials with

linear leaves; a small genus of but few species confined to the tropics and subtropics of the western hemisphere.

The scarcely infuraterl, acuminate fruit, the margins of the lemma inrolled at the base only, the pale free for its upper half, and the absence of the glumes, taken in combination, together with the spreading or

Dichromic Schecht. Bot Z it. 10:15-17. 1852. 
reflexed racemes approximate at the summit of the culm, are here taken as the distinguishing characters of this genus.

Besides the species placed in this genns by Hitchcock (1. c.) a third South American species belongs in the genus, Reimarochloa aberrans (Doell), Reimaria aberrans Doell (Mart. Fl. Bras. 2² 35. pl. 13. 1877) "Habitat prope Santarem provinciae Paraënsis ( R. Spruce n. 851 et 8S7.)" The type specimen. Spruce \$5I, was examined in the Munich Herbarium. In this species the second glume is occasionally present on racemes with glumeless spikelets.

\section{Genus PASPALUMI L.}

Paspalum I. Syst. Nat. ed. 10. 555. 1759. After a brief diagnosis four species are given, $P$. dimidiatum, $P$. virgatum, $P$. paniculatum and $P$. distichum. All agree with the diagnosis, though the last, with acute fruit, might be excluded from eligibility as type species because the generic diagnosis reads: "Cor. Gluma * * * obtusa." None of the species are figured in the same work, none are economic nor indigenous trom the standpoint of the author. Paspalum virgatum and P. paniculatum are here first published, $P$. dimidiatum being the only one previously described. For this reason and also because it is the tirst species under the genus it is here taken as the type. This is given as follows: "Aimidiatum a $P$ [aspalum $]$ spicis subsolitariis, pedunculo communi membranaceo. Panicum dissertum sp. pl. 57. n. 6." There is nothing to explain why Linmaeus changed the specific name. This is discussed by IIitcheock (Contr. Nat. Herb. 1: : 115-116. 1908) who examined in the Limnaean Herharium the type specimen, upon the sheet of which Linnaens wrote both " dimidiatum", which is crossed ont, and "dissectum." The plant is also marked " $\mathrm{K}$ ", which indicates that it was collected by Kalm. In the second edition of the species Plantarum (page 81. 1762) Linnaeus corrects himself, giving the name Paspalum dissectum L. based

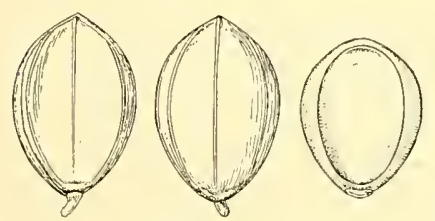

Fig. 8.

Paspalum dissectum.

(Two views of spikelet and fruit $\mathrm{x} 10$ diam.) upon "Panicum dissectum Sp. pl. 1. p. 57." (For a full discussion the reater is referred to Hitcheock's paper.) The specimen belongs to the species long known under the name Paspalum membranaceum ITalt.

The masculine form Paspalus was used by Flügge (Gram. Monog.51-190. 1810) Roemer and Schultes (Syst. Veg. $2: 290-317.1817$ ) and by Nees (Agrost. Bras. 18-82. 1829).

Digitaria Heist. in Fabr. Enum. Pl. Hort. Helm. 207. 1759. This name is given as follows: "Digitaria Heist. Dactylis Rai. Granen dactylon majus panicula longa, spicis pluribus nudis crassis. Sloane." This phrase name in Sloane (Voy. Jam. 1 : 112. pl. 69. f. 2. 1707) refers to the species later published as Paspalum virgatum L., sloane's specimen of which was examined in the herbarium of the British Museum. This phrase 
name Linnaeus first cites (as the third synonym) under Panicum dissectum (Sp. 1'l. 57. 1758), but erroneously, the plate being an illustration of a very different species from the type of $P$. dissectum in the Limnaean Herbarim.* Linnaems later (S]. Pl. el. ‥ \$1. 1762) cites this plurase name and plate unler Paspalum rirgatum and also (op. eit. 1483), erroneously, minter Andropogon fasciculatum. According to the American Corle of Botanical Nomenclature (Canon 10) the publication of Digitaria Heist. as a genus would depend upon the specific description [from Sloane] "associable by citation with a previonsly publishecl binomial species." While this specific description is cited under Panicum dissectum it is erroneonsly so; the species to which the description (as well as the figure) applies has no "previously published binomial," and therefore in the technical sense is not published.

Sabsab Adans. Fan, 2:-31, 599. 1763. No speeies are given. The technical publication of the name is based upon the citation of "Paspalum. Lin."

Cleachne Roland. in Ruttb. Acta Lit. Univ. Hafn. 1:2855. 1778. The name " Cleachue R." appears to be given as a synonym of Puspalum, three umpublished names of the latter being mentioned without descriptim.

Ceresia l'ers. syn. 1'l. $1: 85$. 1805. A brief diagnosis is given and a single species re elegans I'ers. (1.-e.). is citel. This name is based on "Paspahm memhranaeem Lam. ill. gen. p. 177. t. 43. f. 2. Hab. in Pern." The generic liagnosis appears to be taken from Lamarck's specific leseription, lut slightly rearrangel. Lamarck's specimen has not been examiner, but the dexcription and figure indicate one of the species related to Pospalum stellatum Humb. \& Bonpl. and probably that representerl by Ciarlner's Plants of Brazil no. 40.9 and Bang's Plantae Bulivinate no. 1080. Lamarck's name is preocenpied by W' -P. membranacem. Roemer is schultes (syst. Veg. 2: :290. 1\$17) give $P$. eleguns, based on Ceresice elegans Pers., as a synonym of P. membranarenm Lam., but this binomial also is preocenpied l,y $P$. elegans Flügge ( iran. Monog. 1s:., 1810); P. commersonii Zuce. (in Roem. Collect. 12:2. 1509), which appears to refer to this species, is preoceupied by Lamarek's nee of the same name. It seems probable that this species has somewhere received a name that will prove tenable, lut as yet we have not found it. Trinins and Doell use the name $P$. membranacenm Lam.

Reimaric Flügge. Gran. Monog. 213. 1810. The "character essentialis" given is as follows: "Calix uniglmmis, nuifloris, valvae planiori appressus. Corolla plano-convexa, bivalvis," to which is alded the olservation "Paspalo affinis, at satis superque differt calice constanter uniglumi nee ligrlumi." It will be seen that the absence of both glumes is the only character given to differentiate this proposed genus from Paspalum. Three species are included, R. candida Humb. \& Bonpl., $R$. elegans and $R$. acuta, all here described for the first time. The first

* For an account of the types of American grasses described by Linnaeus see Hitchcock (Contr. Nat. Herb. $12: 114-127.1908$ ). 
two are speeies of Paspalum in which both glumes are wanting, the third has characters sufficiently distinct to be referred to a different genus. (See Reimarochloa Hitche, of which $R$. acuta is the type.) Since the three species cited belong to two genera, it is necessary that the name Reimaria go with the larger group. (See Hitchcock, Contr. Nat. Herb. $12: 195$. 1909.) Of these two species we take the first as the type species. This was lescribed from a plant collected "Prope Puanbo in Aneriea meridionali. Humbold et Bonpland." Flügge gives "Humboldt et Bonpland" as the anthors of the species. Kunth later (Mem. Mus. Par. 2: 68. 18In) transferred the specific name to Paspalum. A part of the type or a duplicate of it marked "ex Hb. Kunth \& Hb. Humb." was examined in the Berlin Herbarium. It is the speeies distributed as Paspalum candidum H. B. K. by John Donnell Smith and by the Herb. Instit. physico-geogr. nat. costaricensis, and represented in the National Herbarium by John Donnell Smith 499-2, Tonduz \$ 492 and several others collections trom Costa Rica and Guatemala. Doell (Mart. Fl. Bras. $2^{2}$ : 39.1877 ) proposes a section Eremachyrion for the species of Paspalum in which both glumes are wanting.

Paspalanthium Desv. Opnsc. 59. 1831. This genus, which is diflerentiatel from Paspalum by the loose glume and sterile lemma exceeding the fruit and by the membranaceous rachis, includes a single species $P$. stoloniferum Desv., based on Paspalum stoloniferum Bose. (Trans. Linn. Soc. ㄴ: 83. pl. 16. 1794 "H. in Perua"). The type specimen was examined in the Bosc Herbarium at Padua. It is the species frequently cultivated under this name, with thin, conspicuously rugose sterile lemma. = Tasp. racemosum Lam.

Moenchia Wender in Stenr. Nom. Bot. ed. 2. 2 : 15\%. 1841, not Roth. 178s. There is no description and a single nomen nudum, M. speciosa Wender, is given as a synonym of Panicum sacrharoides Kunth, upon which is based Paspalum saccharoides Nees.

Anachyris Nees, in Hook. Kew Journ. 2 : 103. 1850. A single speeies, A. paspaloides Nees "In Brasilia. Gardner, 11. 4031 in herb. Lindl.," is included. A portion of a raceme from the type specimen was kindly sent by the herbarium at the University of Cambridge for deposit in the National Herbarinm. The species is of that small group including Paspalum malacophyllum Trin, and P. elongatum Griseb., in which both glumes are wanting and in which the very convex fertile lemma is longitudinally grooved. This accounts for the mistake made by Nees in placing the proposed genus in Oryzeae. In this group the fruit is rather reacily detached from the spikelet leaving the thin sterile lemma attached to the rachis. It must have been such a fruit, mistaken for the entire spikelet, that Nees had before him when he deseriked the genus.

Steudel (Syn. Pl. Glum. 1 : 83. 1854) spells this name Anachyrium.

Maizilla Schlecht. Bot. Zeit. 8:601, 605. 1850. A single species is given, " M. stolonifera Bosc. sub Paspalo."

Cymatochloa Schlecht. Bot. Zeit. 12:817, 821. 1854. Two species, "C. fluitans N[o]b. (Ceresia fluitans Ell. * * *)" and "C. repens 
No. (Paspalum repens berg.)," are inchuled, the first of which is here taken as the type.

Dimorphostachys Fonru. Compt. Rend. Acald. Sei. Paris, $80: 4+1$. 1575. This genue is proposed beeante of the presence of the first glume of the spikelet, this glume in the lower of the pair of spikelets being larger than in the upper. The anthor says the group contains eleven species, hut four of which he mentions, Panicum monostrchyum H. B. K. Paspalum pilosum Lanı., Paspalum oajucense Stenul., and Paspalum pedunculutum Poir. Fournier does not here actually transer any species to Dimorphostachys. His first named species, which we take as the type, was, together with the others siven in his posthmons work (Mex. Pl. "2: 14-16. 1886*), published moler this genus by llemsley (Biol. Centr.

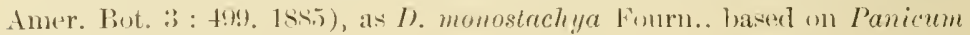
monostuchymu H. В. К.

The setion ITarpostachys of Paniem estahlished by Trinins (Mém.

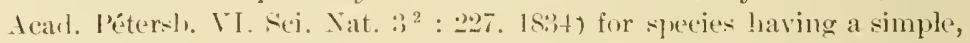
solitary rateme, if typified by the tirst arromp of sprecies included in it, Panirum decumbens Roem. \& Schnlt. (based on Paspalum decumbens Sw, of which I'. pedunculatum Poir. is a synongm) and P'anicum monostachyum II. I. K.. is synomymons with Dimorphostachys. In this section, howerer, Trinims inclused a nmmber of remote species, the wholly artificial character on which it is based hringing together, hesides the two spedes of Pespalum nentioned above, Thrasya paspaloides H. B. K.

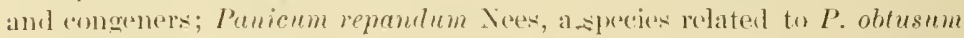
H. B. K., Echimolafna hirta, and I'anicum sclerochloa Trin. and other suecies referable to Mesosetum.

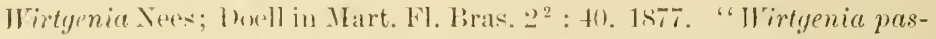

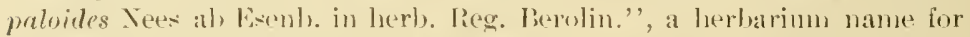
the -pereses Nees published al Inachyris paspuloides, is here given as a synonym of P'aspalum malacopheyllume Trin.

The relationship of the varions seredes nuon which are haved the proposed genera here includert as symonyms of Paspolum together with the

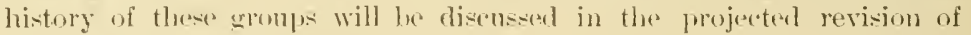
Corth American species of I'aspalum.

Deseription.-Dnfloresente of 1 to numerous, simple, spike-like racenes, along a eommon axis; spikelets plano-convex, nowally obtnke, subsessile (rarely on perdicels as lones as the spikelets) solitary or in pairs, in two rows on one side of a narrow or dilated rachis, the back of the fertile lemma turned towari it; $\uparrow$ first glume typically wanting (regularly present in a few speeser, oreacionally present in others; in a few species both glumes wanting); secomb glume am sterile lemma snbequal, the glmme rarely slorter; froit manally ohture, the lemma ambl palea chartaceonsindurated (rarely but slightly so), thes margins of the lemma inpolled.

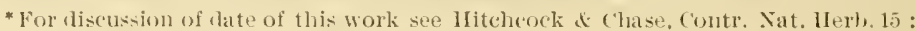
49. 1910.

towing to a tortion of the slort pedicels the cowrled, pativer spilielets are often turmed erlgewise to the rachis or even entirely reversed. but in all speries examined the spikelet is attached with the back of its fertile lemma toward the rachis. 
Mostly perennials, of varions habit; a large genus of the tropies and warm temperate regions of both hemispheres, bnt the species much more numerous in the western hemisphere.

The characters here consideren as of chief generic value are the strictly racemose inflorescence, the plano-convex (sometimes slightly concavoconvex) spikelets in which the first glume is wanting, and the olutuse, indurated fruit, the margins of the lemma inrolled, taken in combination. But in this large, on the whole well-marked genus, there are many species which depart more or less from some one or two of these characters.

\section{GENUS PANICUM L.}

Panicum L. Sp. Pl. 55. 1753. This genus is dircussed by Hiteheock \& Chase (Contr. Nat. Herb. 15:11-18. 1910) and the type species shown to be Panicum miliaceum L. The generic names included as synonyms
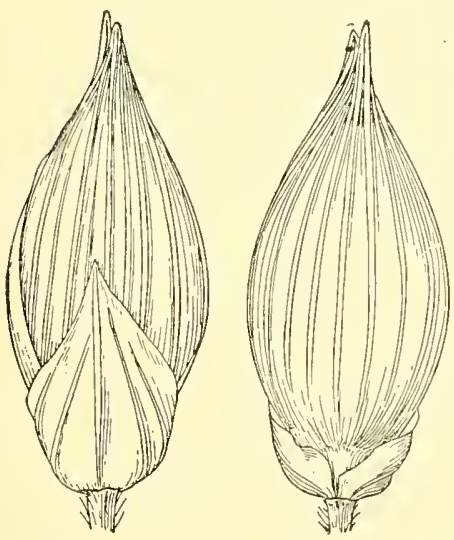

Fig. 9.

Panicum miliaceum.

(Two views of spikelet and fruit $x$ 10 tiam.) under Panicum, so lar as these are based on North American species, are there accounted for. The genus in relation to the South American and Olel Wrord species upon which genera have been proposed will be discnssed in a later paper. In the above mentioned work, under the genera exclurled

from Panicum (op. cit. 16), is giren Panicum tuercheimii Hack., "an anomalous species with spikelets in which the first glmme is wholly wanting, and in which no rudiment of a palea is found in the sterile lemma." This statement is found to be prartly erroneous. There is present a small hyaline first glume, so transparent as to be invisible in the try spikelet, which escaped the notice of Hackel and of ourselves. This species, thongh unique, we now include in the genus Panicum. It will be described and the spikelet figured in a forthcoming paper (by Hitchcock \& Chase) on the Mexican and Central American species of Panicum, a supplement to the recent revision of the genus.

Chasea Nieuwl. Amer. Midl. Nat. 2:63, 64. 1911. This name is proposed as "nov. nom. Panicum of the authors not of Linnaeus or only 
in part." The author states that he "restores" the "name Punicum to the group of plants to which it was applied as far lack as nearly two thousand years ago," overlooking Bubani's restoration of the same name to the same group in 1901 (Fl. I'yren. 4 : 26i1) and the fact that Adanson, Niller and Noench, applied the name Panicum in the same way. As shown in the revision of North American Species of Panicum (Hitcheock \& Chase, Contr. Nat. Herb. 15: 13. 1910) "the historic type species of Panicum is Chaetochloa italica", and the pre-Linnam name for the genus containing Panicum miliaceum is Milium. Nienwland, while maintaining Panicum for the pre-Linnaan genus of this name, overlooks Milium Tourn., the historic name of the gemus containing Panicum miliaceum, amel also the post-Limiean Urochloa Beauv. (Ess. Agrost. 5:. 1)l. 11. f. 1. 1512.) baserl on $U$. panicoides Beany, which is the sane as Panicum helopus Trin., an Oht World species of the Fasciculata group of Panicum; Thalasium spreng. (Syst. Veg. 4 : cur. post. 30. 15:7), liased on a South American species allied to Panicum ureilleanum Kuntlı; Steinchisma* Rat. 1827; Eriolytrum Desv. in Kunth (Rév. Gram. 2 : 217. 18:30), hised on a South Anerican specimen of $P$. urvilleanum or an allied species; and Phanopyrum Nash. The anthor (op. cit. 61) states that the "other group [I'anicum L. exchuling Panicum italicume and its congeners] has never to my knowledge received a name," and (op. cit. (ii)) that "This procelure leaves the other gems hitherto called Panicum by the anthors, without a name, as far as 1 am al,le to ascertain, and I propose that of (hasea." Since this is proposerl as a new name for "Panimm of the anthors" and no particular authors are mentioned, $\uparrow$ we take it as haserl upon P'enicum as used by Beauvois (Ess. Agrost. 45, 169, 176, 171. 1812) who, besides recognizing Puspalum L., Digitaria Hall., Cynordon and Penhisetum Pers., segregates Setaria and Echinochloa, leaving in Punicum the remainder of the species inchderl by Linnaeus unter that genns, that is the group, of Pauicum miliaceum and its congeners.

\section{Genus ICHNANTHIS Beanv.}

Ichnunthus Beanv. Ess. Agrost. 56. 11. 12. f. 1. 1812. The genus is based on a single species, I. panicoides Beanv. (op. cit. 57), " crôt dans l'Amérique méridionale: elle m'a été commmiquée par M. Desfoxtanes." The generic description is erromeons in that Beauvois mistook the appendages at the base of the fruit for an abortive floret placed, he says, contrariwise to the other florets. (It was from this supposed abortive floret that Beauvis derived the name Ichnanthus.) W'e have not seen Beauvois' specimen. The figure, though slightly inaccurate, is a good illustration of the sjecies well described and figured by Kunth (Rév. Gram. 2: 245. pl. 34. 1830) under the name Ichnanthus panicoides.

* This and Phanopyrum are discussed in Contr. Nat. Herb. 15:18, 118, 327. 1910.

+ It might be inferred from the name proposel that Hitchock and ('base, authors of the North Anerican Species of Panicnm, were referred to, but this work is nowhere mentioned by Nieuwland, nor is the source of the proposed nane given. 
Navicularia Raddi, Agrost. Bras. 38. pl. 1. f. 5. 1823. Three species are included, $N$. hirta, N. glabra and $N$. lanata (op. cit. 40. pl. 1. f. 5). The last-named species, "Invenitur in herbidis prope Rio-Inhumirim", is

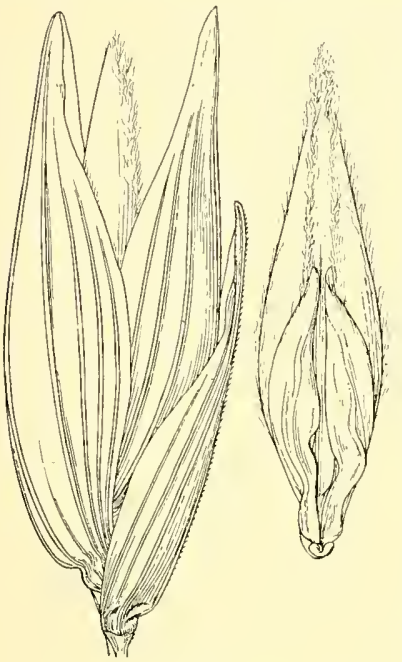

Fig. 10.

Ichnanthus panicoides. (Spikelet and fruit $\mathrm{x} 7 \frac{1}{2}$ diam.) here taken as the type since it is the only one of the three figured in the same work and becane Raddi, in his generic description, refers to this figure. We have not seen Raddi's specimen, but from the description and figure we judge it to be the same as Panicum leiocarpum Spreng. (Ichnanthus leiocarpus (Spreng.) Kunth), to which Nees (Agrost. Bras. 147. 1829) refers it, or a closely allied species. Rarldi proposes the genus because of the peculiar calyx-like structure which is borne on the hermaphrodite floret.

The genus Ichnanthus has been recognized by some anthors as valid and by others has been included in Panicum. Trinius at first (Funrl. Agrost. 130. 1820) accepts Ichnanthus, even to the "transverse" abortive floret, but later (Gram. Pan. 52, 53. 1826) he includes it in his Panicum, section Jubaria, with the observation that it is included in Panicum, having, like "Pan. almadense, pseudagrostis, Hofmanseggii, melicarium", a hermaphrodite floret appendiculate at the base with a donble rudiment.

Nees (Agrost. Bras. 149. I829) includes Ichnanthus panicoides, which he here renames Panicum ichnanthum, in Panicum, section Virgata, placing it next after Panicum leiocarpum and P. Hoffmannseggii, species now recognized as belonging in Ichnanthus. Nees lescribes the perfect floret as being embraced at the base by an ovate, appressed, papery, two-parted lamina.

Kunth (Rév. Gram. 1 : 41. 1829) accepts the genus Ichnanthus with the single original species, and describes the fertile lemma as bearing at the base oblique-oblong, obtuse, glabrons scales decurrent on the perlicel. Later (op. cit. 2 : 245.1830 ), while still inclnding but the single species, Kunth, in his observations, states that the supposed hypogynons scales of authors are analogons to the lodicules which are ordinarily found only at the base of the interior palet (palea) but are here found also and greatly developed, on the exterior palet (lemma). In a later part of the same work (op. cit. 2 :508. pl. 168. 1831) he transfers to Ichnanthus Panicum leiocarpum Spreng., a species in which the appendages are prominent. Still maintaining the genus solely on account of the appendages at the base of the perfect floret, Kunth (Enum. PI. $1: 135.1833$ ) adds Panicum almadense Nees to Ichnanthus. 
Trinins (Mém. Acarl. st. I'étersb. VI. Aci. Nat. $?^{2}: 195,320.1894$ ) make. Ichnanthus (-pelling it "Ichnantus") a section of Panicum, with the symoptical healing "Flosmulns * * * hermaphroditus basi faciei

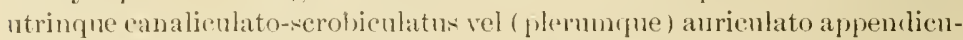
latus," thus indicating the group as to-day accepted, inchuling species in which there is a scar or excavation at base as well as those having appendages.

stenklel (syn. I'l. (itum. 1 : 9:3. 18.5) follows Trinims.

Bentham (Fl. Ihomgkong. $41:$. 1 1stil) adopts Ichuanthus as a genus in this enended sense, incluling in it $I$. pallens (sw.) Mnnro.

Griselach (F). Brit. W' Ind. 550. 186t) gives it, in the same sense, as a section of Panicum.

Doell (Mart. Fl. Bras. $2^{2}: 27 \pi$ ti. 1975) maintains Ichnantleus as a genus for the gromp sogregaterl as Ponicum, section Ichnanthus by Trinise, making muler it two divisions "I Vatvnla inferior ad lasin utriurque anricnlatus," and "If Valvula inferior an basin ntrinque scrobirislata."

lienthan ( lientlı. \& Honk. (isen. 1'l. : : : 1109. 1883) and Hackel (Engler

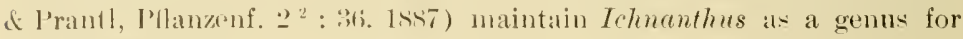
this larger group.

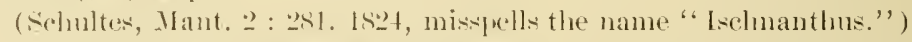

Deseription.-InHoresence pranienlate, the spikelets mostly shortpediceted along the wsially sub-simple branches; spikelets more or less laterally compreserl, the ghunes and sterile lemma strongly nerved; first glume w-11ally more than laalf the length of the spikelet, broal, acute;

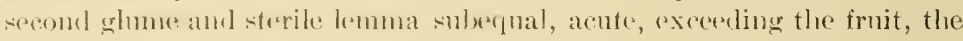
lomma coldosing a membranacens patea amd rarely a staminate flower; frnit acoute or sulaceste, indurated, the marenins of the lemma usually flat,

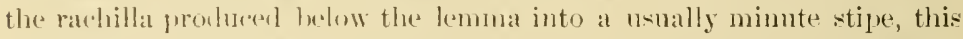

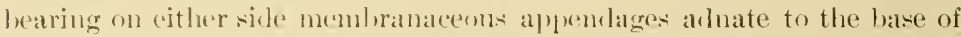
the lemma and frees alove, the appendages smotimes wanting and indicaten by nimute excatrations nuly. I'eremials, msully with lanceolate hlarles abruptly antrated into a petiole-lika base; the genus mostly conlined to the tropis of the western hemisphere, one species extending into

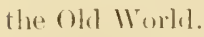

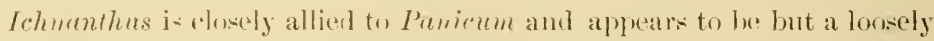
coherent gremus, several of the spereser differing from each other almost as mmely as some of them differ from strecies of Punicum. I few species, snch as $I$. lancelatus serihn., in which the appendages are wholly want-

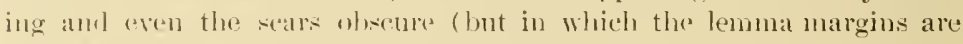
tlat), are nearly as referable to one gents as to the other.

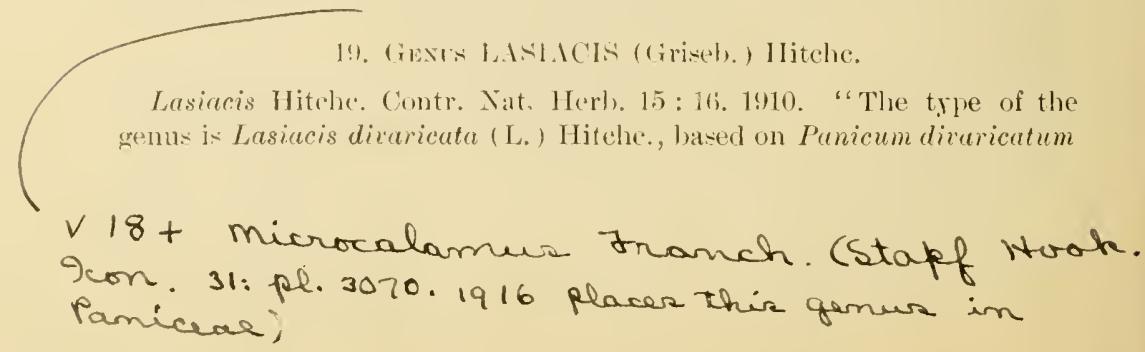


L., the type of Grisebach's section." The author raises Panicum, section

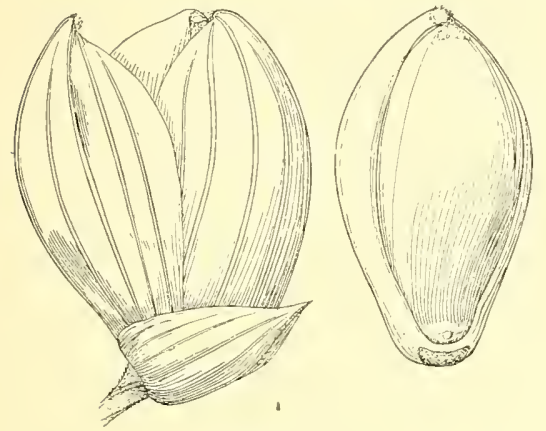

Fig, 11.

Lasiacis divaricata.

(Spikelet and fruit $\mathrm{x} 10$ diam.) Lasiacis Griseb. (Fl. Brit. W. [nct. 551. 186t) to generic rank. The type specimen of Panicum divaricatum L. (Syst. Nat. ed. 10. 2: : 871. $1759)$ was examined in the $\mathrm{lin}$ naean Herbarimm. It was collected loy Browne in Jamaica.

Description. - Inflorescence of open, rarely compact, panicles at the ends of the culm and branches; spikelets sul)globose, placed obliquely on their pedicels, the glmmes and sterile lemma broarl, abruptly apiculate, papery-chartaceous, shining, many nerved, glabroins, or lanose at the apex only, the first glume rarely over $1 / 3$ the length of the spikelet, somewhat inflatedventricose, the second glume and sterile lemma subequal or the glume slightly shorter, the lenma enclosing a membranaceons palea and sometimes a staminate flower; fruit white, bony-indurated, obovoid, obtuse, both lemma and palea bearing at the apex in a slight crateriform excaration, a tuft of woolly hairs, the palea concave below, giblyous above, the apex often free at maturity. Large perennials, usially with freely branching, woody culms, often forming tall half-shruls; leaf-blades firm, often narrowed to a petiole-like bave; a genns of some fifteen species confined to the tropies and subtropics of the restern hemisplere.

This genus is unusually well marker, the spikelets particnlarly of all the species being strikingly similar.

Besides the species placed in this genus by Hitcheock (Contr. Nat. Herb. 15 : 16. 1910 and Bot. Gaz. 51 : 301, 302. 1911) the following North American species, taken from the manuscript revision of the genns Lasiacis, are here transferred:

Lasiacis liebmanniana (Fourn.) Hitchc,

Panicum liebmannianum Fourn. Mex. Pl, 2 : 39. 1886.

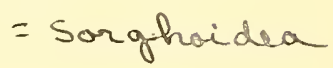

Lasiacis oaxacensis (Stend.) Hitchc.

Panicum oaxacense Steud. Syn. Pl. Glmm. 1 : 73. 1854.

Lasiacis ruscifolia (H. B. K.) Hitche.

Panicum ruscifolizm H. B. K. Nor. Gen, \& Sp. 1: 110. 1816.

Lasiacis rhizophora (Fourn.) Hitche.

Panicum rhizophorum Fourm. Mex. Pl. 22:31. 1880.

Lasiacis procerrima (Hack.) Hitche.

Panicum procerrimum Hack. Oesterr. Bot. Zeitschr. 51 : 431. 1901. 


\section{Gexis SACCIOLEPIS Nash.*}

Sacciolepis Nash in Britton, Man. 89. 1901. Based on a single species, S. gibba (Ell.) Nash, which is the same species as Holcus striatus L., the latter name heing later transferced to Sacciolepis by Nash to replace S. gibba.

\section{?1. Gexes H IIENACHNE Beam.}

Hymenachne Beauv. Es. Agrost. 48. t. 10. f. S. 181:2. The type species is Agrostis monostachya Poir., which is the same as $H$. amplexicaulis (Rudge) Nees.

\section{Gexts HOMOLEPIS gen. nov.}

Inflorescentia paniculata; spiculae majusculae subinsiformes; ghmae subaequales vel prima pandum longior, $7-4$ ) nerviae, floseulos (et sterilem et fertilem) ocenltantes; lemma sterile vix ghmis aequilongum, latius fertili idque amplectens et paleam angustam lyylinam includens atque interdun tlorem cum staminibus; fructus ellipticus acutus laevis nitidus; lemmate paleaque quam in Panico minus induratis, lemmatis marginibus planis.

Herbae perennes, stoloniferae, norlis radicantes; culmae floriferae basi plus minusve decumbentes.

Nomen a ônoos similis, et $\lambda \epsilon \pi i s$ squama.

Inflorescence paniculate; spikelets rather large, subfusiform; first and second glume enual or the first slightly the Jonger, $i$ - to !-nerved, the pair wholly covering the sterile and fertile forets; sterile lemma nearly as long is the glumes, broad, enfolding the fertile lemma, and enclosing a narrow hyaline palea and sometimes a staninate flower; fruit elliptic, pointed, smootl and shining, the lemma and palea less indurated than in Panicum, the margins of the lemma tlat.

Perennials, sending out long leafy runners, rooting at the nodes, the in flowering culms more or less decumbent at base. Confined to the tropics of the western fiemisplere. Nante from öpows, alike, and $\lambda \in \pi$ is, scale.

Type Panicum atureuse H. B. K.

Homolepis aturensis (H. B. K.)

I'anicum aturense H. B. K. Nox, Gen. \& Sp. 1: 10: pl. 33. 1816. "creseit anl eataratas Aturensi-." The type specimen, in the Bonpland

look up

Panicum

olyrachne!
Herbarium in the Muséum a'Histoire Naturelle at Paris, consists of a simple flowering culm, decumbent at lase. The label hears the name and data as published.

Panicum riridiflom Tees, Agrost. Bras. 135. 1429. IJabitat unknown to Tees. The type speeimen in the Berlin Herbariun is laheled "Hb. Ners. Panicum viriliflorum. Panienm aturense Kth.,' followed by a liagunsis. Tees distinguishes his plant from $P$. atmense by the 7 - to ?nerved glumes and sterile lemma, these being erroneonsly described by Kunth as 3-nerved.

* This and the following genus were discussed and the spikelets of the type species figured in Proc. Biol. Soc. Wash. 21 : 1-10. 1908; only a summary is here giren. 
Panicum blepharophorm Prest, Rel. Haenk. 1:312. 1830. "Hab. in Mexico." The type specimen is in Presl's Ilerbarium in the Bohemian National Museum at Pragne.

Panicum turmesrens Trin. Mém. Acad. St. Pétersb. VI. Sci. Nat. $3^{2}: 316$. 1834. No locality other than Brazil is given. In the Trinius Herbarium is a specimen collecter by RiedeI in Bahia. Brazil, in 18:31, marked by

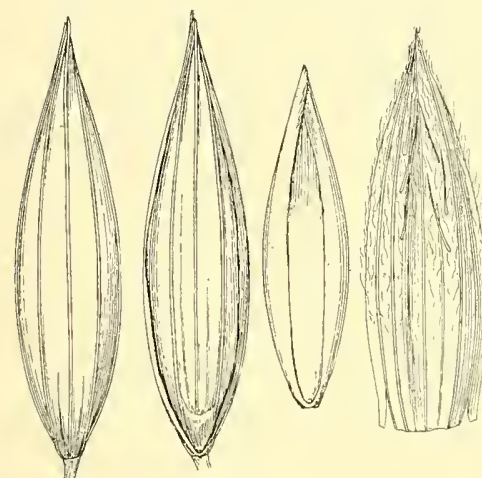

Fig. 12.

Homolepis aturensis.

(Two views of spikelet, fruit and sterile lemma $\times 6 \frac{2}{3}$ diam.)

Trinius "Panicum tumescens m.," which is no doubt the type.

Hilium orinoccense Willd.; Steut. Nom. Bot. ed. 2. 2: 146. 18t1. This is given as a synonym of Paricum aturense H. B. K.

Homolepis isocalycipa (Meyer).

Panicum isocalycinum Neyer, Prim. Fl. Esseq. 59. 1818. “In arenosis umbrosis continentis", Essequibo [British Guiana]. A specimen of this sent by Meyer was examined in the Trinius Herbarium.

Panicum Langei Fonm. Мex. Pl. 2:23. 1886. "Teotalcingo (Liebu. n. 4:5. junio)." The type specimen is in the herbarium of the

Botanical Garden of the University at Copenhagen.

In the National Herbarium there is a specimen of $H$. isocalycina collected by Salzmann in Bahia, Brazil, and distributed withont number, as "Panieum zizanioides H. B. K." It is distinguished from $I$. aturensis by the slightly shorter, more turgid spikelets, with a glabrous sterile lemma and more indurated fruit.

\section{Homolepis longispicula (Doell).}

Paricum longiflorum Trin. Mém. Acad. St. Pétersb. VI. Sci. Nat. $3^{2}$ : 317. 18:4, not Gmel. 1796. No locality other than Brazil is given. In the Trinins Herbariom is a packet of spikelets marked "Panicum longiflorum m. Brasil," and a specimen bearing the same name and also "no. 147. Lect.-?'

Panicum longispiculum Doell in Mart. Fl. Bras. 22 : 261. 1877. "Habitat in Brasilia, loco accuratius non adnotato (herb. Acad. Petropolit.)." Doell cites "Paspalum longifforum Trinius in Act. Petrop. 1835. p. 307 non Gmelin syst. Veg. I. 158." This must be an error for Panicum since there is no Paspalum longifformin of Trinius nor of Gmelin. The page reference is also erroneous. Evidently Doell's name is a typonym of Ponicum longiflorum Trin.

Ichnanthus longifforts Benth. Journ. Linn. Soc. Bot. 19: 45. 1881. This is based on "Ponicum longiflorum Trin', though from hisstatement that "in I. longiflora (Panicum longiflorum, Trin.) they [the auricles] are very 
small, but prominent" it seems prolualle that Bentham had some other species under this name. The fertile lemmas in the spikelets of this species in the Trinins Herlnamu are not at all auricled nor are the spikelet-, with their villon-margined seond glumes and villons sterile lemmas, suggestive of Cchmanthus. Buth Trinins and Doell note the affinity of this sprecies to Pamism aturense.

IIomolepis lompispienla differs from both the other species of this genus in laving a drensely silky-rillow margin to the second glume, and a staminate flower in the first floret. The sterile (or staninate) lemma is densely villons, the fruit lunt little indurated as in $H$. atmernsis. The only collection of this of which we know other than that in the Trinius Iler-

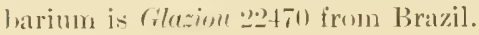

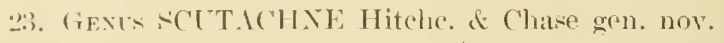

Inforesentia paniculata; spirulae breviter perlicellatae secus paniculae ramos ten ros subimplics dispesitae, fusiformes, acmminatue, basi attennatae, rachilla cum intemoliis elomgatis; ghma frima internodio rachillas inn stipitifomi adnata, ynam spicula tlimilio brevior, membranacea, marginihns basin rersus connatis; gluma secunda lemmayue sterile subaerpilongar, internodio rachillate manifesto separata, coriacea indurata fuca, 5-nerria; lomma sterile palea et interdum staminibus praelitum; fructus ynam ghuma secunda lemmateque sterili, vix indurar tion, ciremecriptions ellipticus, lemmate in moromem pubescentem alrupte angustate, marginibus hasin versus leviter involutis, sursmm planis puberentihs, parte paleace smma banl inclusa, margine dense pubereente.

Herbae peremes, temus, anlmis simplicibms, laminis linearibus, planis, et paniculis angustis.

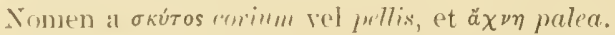

Inflorescence paniculate, the prikeletw shost-paliceles along the slender, simple or nearly simple hrambes; spikelets fusiform, acuminate, the bave attemate, the internokes of the rachilla chongated, the lowermost forming a stipe, the first glume arluate to it ; first glume membranacens, about half the length of the spikelet, hrowl, the nargins connate below; second glume and sterile. lemmat suhergual, a manitest internote of the rachilla hetween them, lasthery-indurated, brown or bownish, i-nerved, the lemma enchsing a palca of sinilar texture, (amb in the type species a staminate flower); fruit lut slightly more indurated than the secom glume and sterile ]emma, olliptieal in ontline, the lemma abruptly acuminate into a slemer, densely julnesent tip, the margins sliglitly inrolled

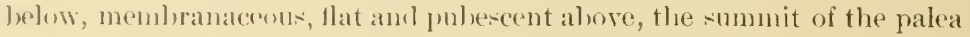
not enclosed, fensely pulserent on the margin.

slemer perennials, with simple culms, linear, flat leaves and narrow

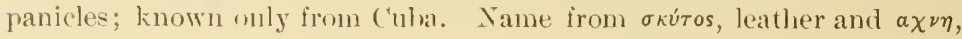
stale.

Type Panirum anmm (irised).

scutache liffer: from other genera of this tribe in laving a second 
glume and sterile lemma leathery-indurated and nearly as firm as the fruit. Bluffia erklomiana Nees (which is referable to Alloteropsis) and Alloteropsis semialata (R. Br.) Hitche., especially the first, have sterile lemmas subindurated like their fruits but the two glumes are similar. The subindurated, mueronate fruit, the lemma margins membranaceous and flat above, the palea free at the summit, further differentiate Scutachne from Panicum.

Scutachne dura (Griseb.) Hitche. \& Chase.

Panicum durum Griseb. Nem. Aner. Acad. n. ser. 8:533. 1862. This
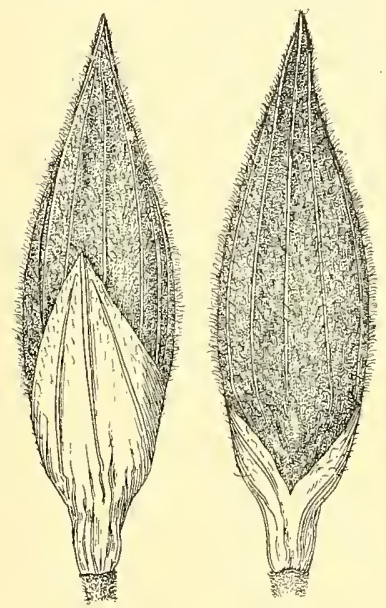

Fig. 13.

Scutachne dura.

(Two views of spikelet and fruit $\mathrm{x} 10$ diam.) was published in Plantae Wrightianae e Cuba orientali; the only citation given is "(1589)." The type specimen is in the Grisebach Herbarium.

\section{Scutachne amphistemon}

(Wright) Hitche. \& Chase.

Panicumamphistemon Wright, Anal. Acad. Cienc. Habana 8 : 207. 1871. "Cerra de Mayarí abajo. [3+6t]." The type specimen, collected by Wright, in the Gray Herbarinm, is labelert "Mayarí-abajo, Aug. 2 , in small dense tufts."

These two species were placed in the genus Alloteropsis Presl by Hitcheock (Contr. Nat. Herb. 12 : 211. 1909) but further study has made this disposition of them appear an

unnatural one. Alloteropsis is unique among the Paniceae in having a minute prolongation of the rachilla beyond the fertile palea. This is not present in all specimens of $A$. semialata examined, though it seems to be constant in Bluffia eckloniana, but its usual presence, together with the awn-tipped glumes and lenma, the glumes of like texture, indicate a relationship too remote from the Cuban species to justify retaining them in Alloteropsis.

\section{GeNus ISACHNE R. Br.}

Isachne R. Br. Prod. Nov. Holl. 196. 1810. The genus is based on a single species, I. australis R. Br. collected by Brown in the vicinity of Port Jackson, Australia. The type has not been examined, but there is no reason to doubt that it is the common species of Anstralia and New Zealand, known under this name.

Isachne has usually been recognized as a valid genus ever since its pub- 
lication. Sprengel (Syst. Yeg. I :314. 1425) describes a I'anicum antiporlum to which he refers Isachme anstralis R. Br. In his earlier works Trinius recognizes Isache as a genus, but in his Panicearum fienera (Mém. Acarl. St. Pétersh. VI. Áci. Nat. $3^{2}: 1 ! 5,32$ s. 1834 ) he rentuces it to a section of Pmicum, and is followerl by stentel ryn. Pl. frum. 1 :94. $18.54)$.

Nees (Agrost. Bras. (ki. 1n:?) gives "Isachne R. Br." as a synonym

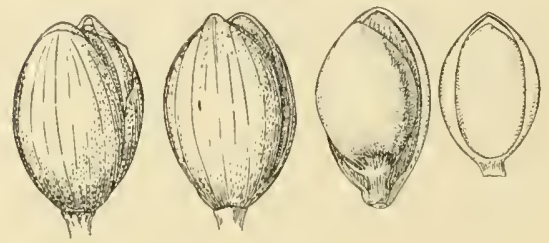

Fig. 11 .

Isachne australis

(Two views of spikelet, florets with glumes removerl. and upuer fruit $\mathrm{x} 10$ tiam.) umder the genus Panicum. But it is to be noted that the only species of Isachlme Nees had in his Agrostologia Brasiliensis was the anomalous Punicum trashyspermum Tees, which is an exception to the genus in that the lower floret is milike the upper. Nees later (Seeman, Bot. Voy. Herald 2024.1857) places this species in Isachne.

Kunth and Bentham give Isullue generic rank, as do Doell, Grisebach and Howker. Bentlan (Fl. Anstr. T: 624. 1sis) places the gents (instead

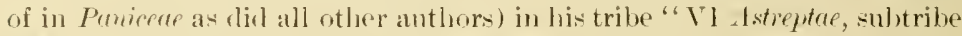
Mitiene," together with syorolwlus, Wiermim, and others, Panicene being his first tribe. This lispowition of the genus appears to have been based on what Pontham in the fienera Plantarmm (:8: 107t, 1100$)$ (alls the subarticulaterl, persistent glumes, since in his introduction to the Gramina in the "Flora Anstraliensis:" Bentham, empluasizing the importance in classification of the articulation of the spikelet, remarks that this character "settles the gosition of a few exenera, Polymgon, Milimm, Istrhme ete. which might at first sight apuear clowely to comnet the two great series." Later (Linn.

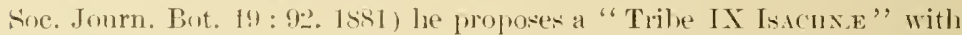
the statement that this is a molification of the sulntribe proposed in the "Elora dustraliensix" nurler the name Miliar. Milium and sirorobolus are not here inclurled. The trihe is placerl between "Acikostex" and

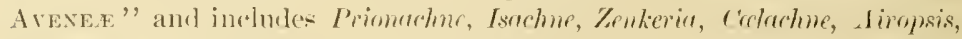

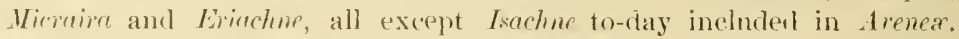
Be+ntham notes the resemblance of Isarfme to some species of Panicum but alels that the "speeses of Iscrlme * * constantly differ in the empty glumes persistent below the articulation, and in the two flowers both lermaphrodite or female, thomgh one may le oceasionally sterile." Hooker (Fl. Brit. Ind. 7 : :2, 221. 1s!6 says that the first and second glumes are separately decidum and that the fonrth glume (lemna of upper floret) is articulate on the rachilla. Ilackel (Engler \& Prantl, Pflanzenf. $2^{2}$ : :35. 1887 ) in the diagnosis of Irrulur says, "the fruiting glumes falling out of the persistent 'mpty glumes." The examination of a large number of specimens scarcely verifies these statements. While the articulation below the glumes is not constant as in other genera of Ponicene, the spikelets appear to fall entire in at least abont half the cases. The glumes appear 
to be commonly separately deciduous, as stated by Hooker, the pair of florets joined together, being found persistent in mature panicles after one or both glumes have fallen. A number of specimens show persistent glumes from which the florets have fallen, but these are much fewer than the persistent florets from which the glumes have fallen. Several panicles liave been found in which both of these occur, but in the great majority of cases the spikelets are either present entire, or wholly fallen--thongh the parts may have fallen separately. The secoml floret articulate on the rachilla, falling separately, appears from the examination of our specimens to occur only very rarely, and then only when the lower floret is staminate, or at least not perfecting a grain. It may here be noted that in Panicum capillare and its close allies the fruit frequently falls from the temporarily persistent glmmes and sterile lemma, and that occasionally in $P$. dichotomum and its allies the glumes and sterile lemma fall, leaving the fruit for a short time persistent.

Bentham later (Benth. \& Hook. Gen. Pl. 3: 1077. 1883) places Isuchne in the tribe Paniceae, immediately before Punicum, and Hackel (Engler \& Prantl, Pflanzenf. 22 : 33, 35. 1887) also assigns it to this position.

Description.-Inflorescence paniculate; spikelets obovoid to subglobose; glumes membranaceous, subequal, about as long as the fruits or at maturity exceeded by these: lower floret perfect or staminate, its lemma and palea indurated and similar in form and texture to those of the npper floret (scarcely indurated and dissimilar in I. trachysperma Nees); both florets (or fruits) plano-convex, obtuse, equal or nearly equal in size (the lower often larger when staminate only), the pair usually remaining attached together by the minute rachilla joint below the upper floret. Perennials with simple or branching culms and flat blades, the species confined to the tropics and warm temperate regions of both hemispheres.

The lower floret often appears to be sterile (not perfecting a grain) in some and fertile in other spikelets on the same panicle. When sterile the floret is often longer and the lemma less convex than when fertile, the spikelets on the same panicle thus having a somewhat diverse appearance.

Several species of Isachne bear a superficial thongh striking resemblance to species of the Torth American Panicum, subgenns Dichanthelium.

\section{Gexus HETERANTHOECIA Stapf.}

Heteranthoecia Stapf in Hook. Icon. Pl. $30^{2}:$ pl. 2927. 1911. The genus is based on a single species, $H$. isachroides Stapf (l. c.) collected in "Tropical Africa: Northeru Nigeria; Nupe, in swamps Barter, 13ts: French Congo; Snussi Comntry (Chari oriental), at the sources of the Nelele River, Chevalier, 68.5." It is not stated from which collection the illustration was made. The genus differs from Isachne in having a racemose panicle, the subsessile spikelets in short racenes, these arranged along a common axis, and in having florets with lemmas dissinitar in form and texture, though both fertile. Stapi considers the genus intermediate between Isachne and Coelachne, the latter an anomalons genus of the Old World at present placed in Aveneae. 


\section{CieNe OPJISMENUS Beaur.}

Optismenus Beam. Fl. l'Oware et Benin. 22: 14. ph. 58. f. 1. 1804.* Tnder the grenus is dexeribed a single species, O. ufricanus (op. cit. 15), of which Beaurois says "J'ai trumé cette espéce à Clomo, à Kots, à Oware et a Bendu." Ile states that the genus is compused of several sprecies of Panicum and notally those of which l'ersoon has male a division thus chatracterized: "Spica composita, spiculis compressis secundis."

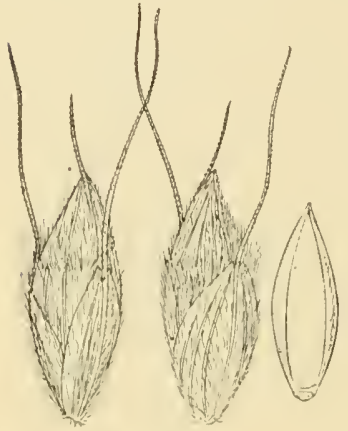

Fig. 1.i.

oplismenus ajicunus.

ITwo views of snikintet and fruil $\times 10$ (liam.) The species included hy Persom (syn. Pl. 1: 82. 1805) in this division are P'tricum hirtellum, $P$. selarium, $P$. bromoides, $P$. cespitosum, P. loliaceum, P. compositum and $P$. elatius. The type specimen of $O$. africanus has not heen examined. The accompanying figure is marke from Zenker of Strudt 515 , collecter in Kamerun, Ifrica, which is inelumed in the region visited by Beambis. (The generic name is mirspelled "Ophismenus" in l'oir.; Lam. Enege. Suppl. t: 271. 1816.)

Oithepogom R. Br. Prodr. Noy. Holl. 194. 1810. Fonr species are given under the grenus, O. compositus, lased on "P'micum compositum I.," O. aemulus, O. flarridus, O. imbecillis. None being fignred in the sime work and all lexing equally eligible the first is here taken as the type.

Cheroman (Man. Xew Zeal. Fl. st!). 1:104) refers IIekaterusachne elatior steme. (from Xew Kealand), the type of the munotypic genus Hekatereserchne steut., to (pplismereus undulatifolius Beauv. Dalla Torre and Harms (fien. Siphonng. 1t. 1900) also refer this name to oplismenns. We have not seren steukel's specimen. Ilis deseription (syn. Pl. Gilum. 1:11s. 1sit) floes not well agree with Oplismoun, though it is jossible that his deceription is erroneols.

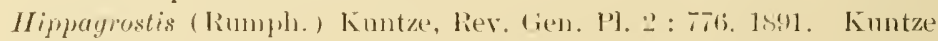
gives Rumpof as the anthor of the genuse, with the date 17f9. Mip-

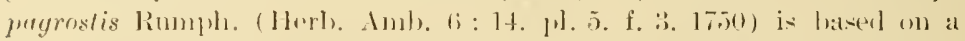
single species, $I I$. ambrinira limmph. (1. c.), which the plate shows to be a species of Oplismenus, probahbly O. burmannii. Since a binomial species is given under the genus, only the fact that "Botanieal nomenclature is treated as beginning with the general application of limomial

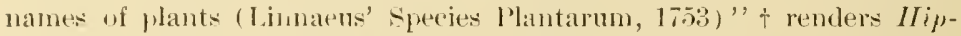
pagrostis invalid for onr nee. In the Index Iniversalis (Herb. Amb. Anctuarium, 1755) the name II ippagrostis amboinica is given with reference to the 175 ) work. Perhajs this might constitute fublication.

* The title page is clated 1407 . The late $1 \times 09$ is taken on the authority of J. II. Barnhart as statel in a letter from G. Y. Xash, to whom we are indebted for a transcript of pages 11 and 15 of the second volume of the Flore d'Oware.

t American Code of Botanical Nomenclature Part 1, principle 2. 
Beaurois (Ess. Agrost. 5t. 1812) amplifies his earlier generic description and transfers to the genus several species from Panicum. He places Oplismenus immediately after Echinochloa.

Ǩnth (H. B. K. Noy. Gen. \& Sp. 1 : 106. 1816) recognizes Oplismenus as a genus, inchuling under it as synonymous Orthopogon R. Br. and Echinochlon Beanv. The same is done in his later works (Rév. Gram. 1 : 43. 18:9; Enum. Pl. 1 : 138. 18:39).

Desvanx (Opuse. 81. 18.31) follows Kunth, but also includes Panicum semialatum in the genus.

Trinius (Fund. Agrost. 181. 18:0) recognizes Orthopogon R. Br. as a genus, referring Oplismemus to it as a synonym.

Raddi (Agrost. Bras. 40. 18:3) recognizes Oplismenus.

Triniu- (Gran. Pan. 51, 158. 1826; Mém. Acad. St. Pétersb. YI. Sci. Nat. $3^{2}: 209.1834$ ) rednces Orthopogon to a section of Panicum.

Yees (Agrost. Bras. 25.5. 18.9; Fl. Atr. Aust. 60. 1841* gives Oplismenus generic rank.

Stendel (Syn. Pl. Glum. 1:44. 1854) follows Trinius in making Orthopogon a section of Panicum and giving Oplismenus as al synonym.

Hasskarl (Cat. Pl. Hort. Bogor. Alt. 16. 184t) and sichlechtendal (Linnaea :31 : 26:3. 1861) spell the generic name Hoplismenus.

Bentham (Fl. Hongkong 409, 411. 1s61) includes Oplismenus in Panicum, but later (El. Austr. $7:$ : 191.1878 ) he gives it (with Orthopogon as a synonym) generic rank "with the limits originally assigned to it by Beauvois and by Brown," that is excluding Panicum crusgalli and allies referred to it by Kunth.

Grisebach (Fl. Brit. W'. Ind. 5tt. 1sit) recognizes Orthopogon as a genus for the gromp, thus circumseribed, and Doell (Mart. Fl. Bras. $2^{2}$ : 144. 18i5) includes Orthopogon, in the same sense, as a section of Panicum, giving Oplismenus as a synonym.

Bentham (Benth. \& Hook. Gen. Pl. 2 : 1077, 1104. 185:3) gives Oplismenus generic rank as toes Hackel (Engler \& Prantl, Pilanzenf. $2^{2}$ : $33,36.1887)$.

Foumier (Mex. Pl. 2: :37. 18s6) maintains Oplismenus as emended by Kunth, that is, including Echinnchlod.

Dalla Torre and Harms (Gen. Siphonog. 14. 1900) give the name Paniculum Ard. as a synonym of Oplismenus. The name "PAXICULUM undulatifolium" occurs in Arduini (Animadr. Bot. Spec. 2): 14. pl. t. 1764), but the generic name is an error for Panicum. The name printed on the plate is Panicum undulatifolium.

Description.-Infloresence of tew to many milateral racemes, approximate or distant along a common, often flexnons axis, the racemes bearing many crowded or subdistant spikelets, or sometimes very short and bearing a single chuter; spikelets terete or somewhat compresed laterally, subsessile, in pairs or solitary in two rows on one sicle of a narrow, scabrous or hairy rachis; glumes subequal, emarginate or 2-lobed (rarely entire), awned or mueronate from between the lobes; sterile lemma ex-

* The second edition of this work was published in 1853 with the title "Agrostographia Capensis." The pagination is the same in both. 
ceeding the glumes and fruit, notched or entire, mucronate or shortawned, enclosing a hyaline palea; frnit elliptic, acnte, the lemma very convex or boat-haperi, the firm margins clasping the lemma, not in rolled. Usmally weak, treely branching, creeping or ascending annuals or perennials, with flat, thin, lanceolate blates, the species confined to the tropies and warm temperate regions of both hemispheres.

In this gents the awns are variable in length in the same species.

\section{2-7. (iENLS ECHINOCHLOA Beauv.}

Echinochlou Beauy. Ess. Agrost. 53. pl. 11. 1. 2. 1812. The first of several species of Panicum listed under this genus, and in the index (page 16il) transferred to it, and the one figured is E. crasgalli (L.) Beanv., which is taken as the type. This species is based on Panicum crusgalli L. (N). Pl. 5t. 1759) "ITabitat in Emrope, Virginise cultis." The only

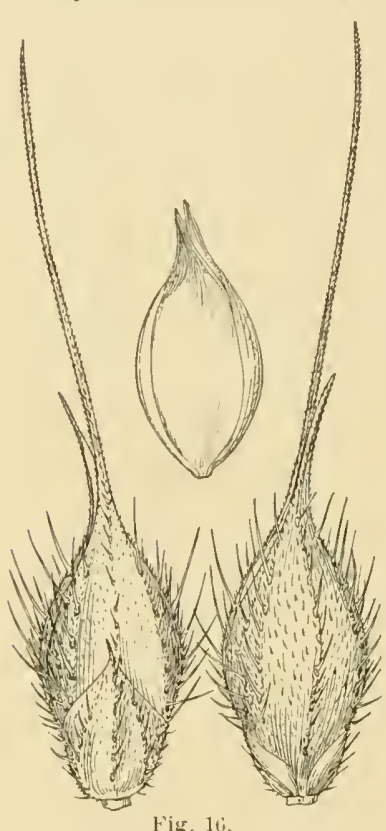

Eichinochloe crusgalli.

(Two views of spikelet anul fruit $\mathrm{x} 7 / 2$ (iam.) specinen in the Limaean Herbarium to which Linnaeus has attached the name is one of the ordinary small form of this species.* This is marked " $\mathrm{K}$ " indicating that it was collected by Kalm in America.

Arlanson (Fam. Pl. "2 : 496, 1763) proposes a genus Tema with the differentiating diagnosis " Corolla ohtuse or aristate on the exterior seale of the sterile flower." No binomial is aited. The anthority for the genus is given as "HI [ort.] II [alab] 1:. t. 7!" (which would indicate that Arlanson arlopts the genus from that work), and "Panicum Rumph, 5. t. Tit. f. ‥" and "Gramen panicem spica livisal C. B." [('ilspar Banhin] are cited. The last eitation refers to Panicum crusgalli L. and is also given by Linnateus muler that species (Sir. Pl. 56. 1753). The plant lexcribed and fignred in Rheede (IIort. Malabar. 12: pl. 79.1703$)$ is Chaetochlon itulice (L.) Scribn. and the name there given it is Tennu, of which Tema would appear to be an erroneons. transeript. The plant illustrated in Rumphins (Herl), Amb, $5:$ pl. 76. f. : 1747) is Eleusine indica. If Adanson meant to unite there species in a single genus, as would appear to be the case, the name Tema would go with the first reference, and, since this is not associable with a previously published binomial the genus is not technically published. It is posible that the reference given to Rumphius is an error for plate 75 , figure 2, this being an illustration of Chaetochloa italica.

\footnotetext{
* See Hiteheock. Contr. Nat. Herb. 12:117. 1908.
} 
Trinins, Nees, and Stendel, of the earlier anthors, include Echinochloa, usually as a section, in Panicum.

Kunth (II. B. K. Nor. Gen. \& Sp. 1 : 106. 1816; Rév. Gram. 1: 43. 1829; Enum. Pl. 1 : 198. 1838) and Desvanx (Opusc. 81. 1831) include it under Oplismenus.

Roemer \& Schultes (Syst. Yeg. 2: 476. 1817), Schultes (Mant. 2 : 266. 1824), and Link. (Hort. Berol. 2 : 208. 18:33) give Echinochloa generic rank, but the latter adds (op. cit. "209) "Genera Echinochloa et Panicum artificialia sunt, nee natura distincta."

Of the later authors Bentham (Fl. Hongkong 411. 1861; Fl. Austr. 7 : 478. 1878; Benth. \& Hook. Gen. Pl. 3 : 1102. 188:3), Grisebach (Fl. Brit. W. Ind. 545. 1864), Doell (Mart. Fl. Bras. $2^{2}: 139.1877$ ) and Hackel (Engler \& Prantl, Pflanzenf. .2 " 35.1887 ) include Echinochloa in Panicum. Fournier (1ex. Pl. 2: 39. 1886) includes E. crusgalli and its close allies in Oplismenus, but Oplismenus holciformis H. B. K., a longawned species allied to E. spectabilis (Nees) Link, he places in Berchtoldia (misspellel "Berchtholdia"). In his key to Paniceae (op. cit. 3) Fournier distinguishes Berchtoldia from Oplismenus by the "remote inferior glmme." (Both genera are included under "Spiculis involueratis ; involucro constante e spiculis abortivis," as opposed to "e chaetocladis" inclnding Setaria, Pennisetum, etc. What Fournier could have mistaken for an involucre of abortive spikelets is not evident.)

Nash (Britton, Man. 78. 1901; Small, Fl. Southeast. U. S. 84. 1903) and Hitcheock (Gray, Man. ed. 7. 117. 1908) recognize Echinochloa as a valid genus.

Description. - Inflorescence paniculate, the usually compact, densely flowerer panicle composed of one-sided simple racemes or of subsimple branches; spikelets plano-convex, often spiny-hispid, subsessile, solitary or in irregular clusters on one side of the panicle branches; first glume about half the length of the spikelet, pointed; second glume and sterile lemma equal, pointed, mueronate, or the glume short-awned, the lemma long-awned, in some species conspicuously so, enclosing a membranaceous palea and sometimes a staminate flower; iruit plano-convex, the lemma and palea smooth and shining, acuminate-pointed, the lemma margins inrolled below, flat above, the apex of the palea not enclosed. Coarse, often succulent annuals, with compressed sheaths and linear, flat blades; species of the temperate and tropical regions, two species cosmopolitan.

In this genus the awn of the sterile lemma is exceedingly variable in length, sometimes even in the same plant. Echinochloa is distinguished from Panicum constantly by the plano-convex, pointed fruit, the lemma margins flat above, the apex of the palea free, and usually by the awned sterile lemma.

A Mexican species described under Oplismenus belongs to this genus:

Echinochloa holciformis (H. B. K.).

Oplismenus holciformis H. B. K. Nov. Gen. \& Sp. 1 : 107. 1816. "Crescit in lumidis montanis prope Cinapecuaro, alt. 970 hexap. (Regno Mexi- 
(ano.)" A duplicate type, received from Humboldt, was examined in the Wilklenow Herbarinn. of the specimens in the National Herbarinn Pringle stio-2 is an excellent match for this. The other specimens mostly have longer awns.

Orthopogon holciformis Spreng. Syst. Veg. 1:307. 15.5̃. Based on "Oplismemes holciformis Kunth."

Panicum holciforme Steur. Non. Bot. ed. 2. 22: 257. 15+1. Based on Oplismemus holciformis 11. B. K.

Berchloldiu holciformis Fonrn. Mex. Pl. 1: 11 . 18st. Based on "Oplismenus holciformis 11. B. K.",

28. Gext' CHAETIUM Nees.

Chatium Nees, Agrost. Brals. 269. 1529. This gemns is based on a sin-

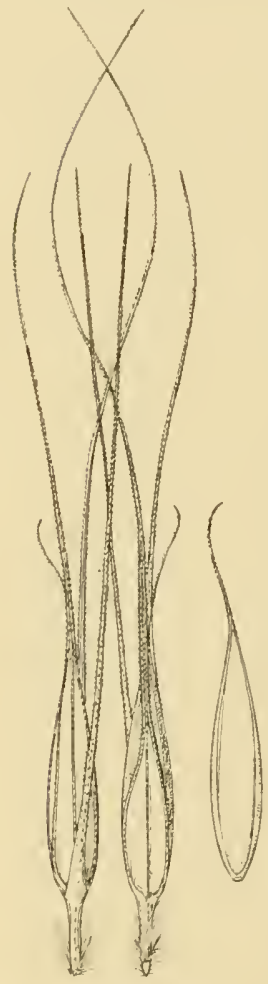

Fig. 17 .

Chaetium festucoides,

I Two views of spikelet and iruit $x$ is diam.) gle speeies, C. festucoides Nees (op). cit. 270), "Habitat in graminosis at in cultis an flumen s. Francesi, ael Joazeiroete. Provinciarum Pernambucanate et Bahiensis." The type specimen, in the Innich IIerbarium, bearing the data as published, was collected hy Martius.

Berchtoldia Presl, Rel. Hatenk. 1 : :303. pl. tis. 16:30. I single speeies is incluterl in the genus, $B$. bromoides Hresl. (op. cit. :'st). "Hab. in Mexico." I part of the type specimen was examined in the Triniss Herbarimm.

Pusth Nees and Presl place their proposed genera next after Hplismenus.

Kinnth (Enmm. Pl. 1 : 1fli. 1s:3is) places Chaetium festueoides in Oplismenus but to Berchtoldia he gives erenerie rank. After the generic destription he adds "(charact. gen. ex Presl. )" It is probable that Kunth hat not seen either suecios, funt that from the plate in l'resl's wurk he resonnized Berchtuldia as distinet from oplismenus.

Steulas (Ayn. Pl. Cilum. 1 : 4s. 1554) places C'haetium in P'unicum, section Echinochlore muter the name $P$. chaetium, and gives (op. ('it. 117) Berchtoldia generic rank, as dial kimoth, and clonbtless for the same reason.

[oell (Mart. Fl. Bras. 22: 150. 1577) makes Chactium a section of Panicum with the single speciess $P$. chaetium stend. In the ofservations (op. cit. 150) he mentions ats helonging in this section Berchtoldia bromoides Presl, to which lie gives the name Panicum bercholdium. Lumler $P$. chaetium he mentions as an extra-Brazilian specimen Ilright 735 from eastern cuba. This number is the type of "Perolis? cubana" Wright, Chaetium cubanum (Wright) Hitche.

Benthan (Limn. Soc. Journ. Bot. 19: \$6. 15s1; Benth. \& Hook. Gen. 
Pl. 3:107, 1104. 1883) recognizes Chaetium as a valid genus, as does Hackel (Engler \& Prantl, Pflanzenf. 22: 39, 36. 1857) both placing it immediately after Oplismenus.

Hemsley (Biol. Cent. Amer. Bot. 3:503. 1885) transfers Berchtoldia bromoides to Chaetium giving Bentham as authority with a reference to the Linnaean Society's Journal mentioned above, but Bentham did not there transier the snecies.

Fournier (Mex. Pl. 2 : 40.1856) gives Berchtoldia as a genus, including in it Presl's species, and also two species of Echinochloa.

Description.-Inflorescence a dense, narrow panicle; spikelets shortpediceled, dorsally comprescel, lanceolate amd having a long, slender callus-like base from the elongation of the joint of the rachilla between the glumes, the bearded base of the first glmme adnate to it; glumes bearing awns 3 to $t$ times the length of the body of the spikelet, the first reduced to the awn or, in $C$. lromoides, the pair broadened and enclosing the rest of the spikelet; sterile lemma bearing a shorter awn or awn-tipped only, the sterile palea obsolete; fruit subindurated, lanceolate, the lemma acuminate into a scabrous awn or point, the thin margins flat, the summit of the palea not encloserl. Perennials with long, narrow leaves; the genus containing but three known species, one of Mexico and Central America, one of Cuba, and one of Brazil.

\section{GENus TRICHOLAENA Schrad.}

Tricholuena Schrad. in Schult. Mant. 2: 163. 18:4. Three species are included in the genus but the second and third are precedect by a question mark, hence the first, T. micrantha schrad, of which Saccharum teneriffe is given as a synonym, is the type.

Rhynchelytrum Nees in Lindley, Nat. Syst. ed. 2. 4t6. 1836. The genus is described and a single species, $R$. dregerenum, given. We have not seen the type specimen but the generic description applies to Tricholaena. Stapf (Dyer. Fl. Cap. $7: 444.1898$ ) refers R. dregeanum to T. rosea Nees.

Monachyron Parl, in Hook. Niger Fl. 190. 1St9. A single species, $\boldsymbol{X}$. villosum, is included. The type specimen has not been examined. Hackel (Engler \& Prant], Phanzenf. 22 ${ }^{2}: 36$. 1857) gives this as a synonym of Tricholaena, and Durand and Schinz (Consp. Fl. Afr. $5: 771$. 18\%5) transfer $\mathcal{M}$. rillosum to this genus. Making allowance for a misunderstanding of the structure of the spikelet, owing to the remote first glmme, the description applies to Tricholaena.

The scarcely indurated fruit, scarcely firmer than the nsually --lobed and awned second glume and sterile lemma, together with the elongation of the rachilla joint between the glumes, serve to distinguish this Old World genus, a single species of which, T. rosea Nees, is sparingly escaped from cultivation in the tropics and subtropies of North America.

\section{Genus CORIDOCHLOA Nees.}

Coridochloa Nees, Edinb. New Phil. Journ. 15: 381. 1833. This genus is based on a single species, "Coridochloa * * * cujus typus est 
Punicum cimicinum Retz." Nees states that the genns is allied to Anthaenatia Beans., but is distingnished by the two-flowered spikelets, the fertile floret aristate.

Bentham (Fl. Anstr. T: t7?. 1STs) gives "Gorichochloa semialata, Tees in varion catalognes and herbaria" as a synonym of Panicum semialatum $\mathrm{R}$. Br., and adds "(the genns not published as generally quoterl in Elinh. New Plill. Joum. 1830, July)." It would seem that Bentham must have cited this name and reference from memory. We ciun not find that Xeps himself ever placerl $P$. semialatum in Coridochloa, nor can we find any reference to the puthlication of the genns in 18:2. It was prohably a slip of memory on Bentluam's part for 1s:3: The genus Coridorhloa is proposer in a footnote with the statement that it will be treated of at another time, lience Bentham may have consilered it as insulficiently published. But Nees states that the grenus belongs in the trilx Panicea, names a type species, previnmsly decoribed, and gives the prineipal distingnishing charaeters of the spikelet. In Wallich's Catalogure (1st9) no. s7t!) "coridochloa limbriata Yees ab Esenbeek" is listerl, "A. Milimm eimicinmm HH. Heyu." and "B. Paniemn cimicinmu Hb. IIant." Treing given moller it. (In a note on page 192 of the Catalogne it is stated that "Mr. Brown * * * has harl the gordness * * * to furnish the provisional list of the fanily" of grasces). In a criticism of Yore, Bentlanu (Limn. Soce. Journ. Bot. 19:15. 1881) again says "Brown's Australian Panicum semiulatum, for instance, is raised by Ness th the rank of a genus uncler the name of Coridochloa in India, and that of Bluffie in sonth . Irica." It may be that Benthan did not know Panicum cimicinum Retz, for (op. cit, t's) he says "I'. semialatum Br. is willety sureal over the Old World, for I am mable to clistinguish the Iriatice Coridochlon, Vees, and the Sonth Dirican Blufier, Nees, from Brown's dustralian suecies.",

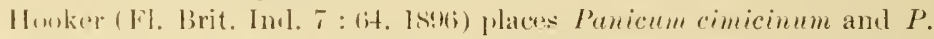
semialutum umier . lonopus beans. (See discussion muler that gemm.) [melel the soment species is given as a synonym "Coridochloa semi-alata,

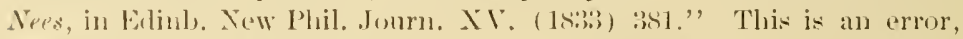
Now makes no mention whaterer of $P$. semialatum nor of any species

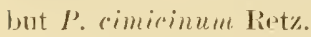

This mique species has leen placed in Milium (by linnaeus) in Punicum (hy Retzins), in Aconopes (by Beanvois), in Crochloa (by Kunth), and finally in Coridorhloa, Jased on it alone, by Nees.

Corichorhor, which is perhaps rather remotely allied to the next genus, i- bistingui-hed hy the concavo-convex, searcely indurated, stipitate frnit, the lemma attennate into an awn alout as long as the body of the fruit, the palea sparely covered with stalked glandular luairs (in appearance like minnte fungi), a few of these sometimes scattered on the margin of the lemma; hy the papery glmues and sterile lemma, the second glune conspicuonsly stiff-ciliate along the lateral internerves, and by the digitate infloresence, the slemder racemes naked at the base or for half their length. 


\section{Genus Alloteropsis Presi.}

Alloteropsis Presl, Rel. Haenk. 1 : 34t. pl. 47. 1830. A single species, A. distachya, is included in the genus which is erroneonsly described. Scribner (Mem. Mo. Bot. Gard. 10 : 37. pl. 33. 1899) and Hitchcock (Contr. Nat. Herb. 1:2 : 210. 1909) explain the error and emend the genus. Presl's type specimen was examined and photographed in the National Museum at Prague by Professor Hitchcock. It is the same species as Panicum semialatum R. Br. (Prodr. Nor. Holl. 192. 1810), Alloteropsis semialata Hitchc. (l. c.). There are two plants of the same species on the sheet, one with a ticket marked "Peruanæ montanæe" the other with one marked "Regio montana, Luzon." The Peruvian locality is clearly erroneons.

Bluffia Nees, Del. Sem. Hort. Hamb. 8. 1834. The genus is described and a single species, B. eckloniana Nees, "ab Ecklono * * * in Africa australi detecti," included under it. By Hackel (Durand \& Schinz, Consp. Fl. Afr. $5: 764.1895)$, this species is reduced to a variety of Panicum semialatum; by Hooker (Fl. Brit. Ind. $7: 64.1896$ ) it is referred to Axonopus semialatus as a synonym, and by Stapf (Dyer, Fl. Cap. $7: 418.1898$ ) it is reduced to a variety of that species. To us it appears to be specifically distinct.

Holosetum Stend. Syn. Pl. Glum. 2:118. 185t. This is based on a single species, H. philippicum Stend. "Herbr. Cuming nr. 1363 et 1414. Ins. Philip." Cuming's no. 1363 was examined in the Kew Herbarium. It proves to be Alloteropsis semialata.

This genus of two known Oh Wrorld species does not appear to be see Maiden closely allied to any other. The two subindurated, awn-pointed florets to some appear to suggest species of Arundinella, under which genus Bentham (Fl. Austr. 7 : 5̆tõ. 1878) describes a specimen of Alloteropsis semialata, as Arundinella Schultzii Benth., though he gives Panicum semialatum on page 472 of the same work. In both species of this genus, as shown by specimens in the National Herharium, there is not infrequently found a rudiment, $0.3 \mathrm{~mm}$. or more long, beyond the palea of the fertile floret.

The genus is distinguished by the amn-pointed, similarly subindurated staminate and fertile florets, the margins of the fertile lemma thin, flat, the palea not enclosed at the summit, in combination with the subdigitate inflorescence, the short-pediceled spikelets in clusters along the racemes.

The involucrate genera and the others excluded uncler the first and second divisions of the key will be considered in a subsequent paper now in preparation. 






